\title{
Augustus Earle in New Zealand: An Early Colonial Artistic Perspective
}

\begin{abstract}
This article surveys the events and individuals encountered by the English artist Augustus Earle (1793 -1838) during his visit to New Zealand in 1827-8. Through his paintings, Earle offers one of the first comprehensive European artistic impressions of parts of New Zealand and its inhabitants prior to the onset of large-scale British colonisation. Many of his conclusions and perspectives were unavoidably subjective, but they at least offer a glimpse into one person's impression of the country at this time.
\end{abstract}

\section{Going to New Zealand}

During 1826 and 1827, while the English artist Augustus Earle (1793 -1838) was in Australia, he painted at least fifteen watercolours of scenes in the Illawarra area. As he travelled through the region, he may well have either come into contact with or entered the orbit of the sixty-one-year-old Anglican missionary Samuel Marsden, whose reputation and achievements on behalf of his denomination were formidable by this time. Marsden had been in Australia since 1794, and in the intervening years, rose to become not only the colony's most senior and well-known cleric, but also - in his capacity as a member of the Bench of Magistrates at Parramatta - a (to some) notorious dispenser of punishments to wayward convicts. He was popularly known as the 'flogging parson' for the alleged severity of the sentences he inflicted, ${ }^{1}$ and in 1826 was appointed by Governor Darling as one of the managers of the Female Factory, where his infamy among convicts spread due to his readiness to have female prisoners whipped.

Professor Paul Moon is Professor of History at Te Ara Poutama - AUT University's Faculty of Maori Development - and is a Fellow of the Royal Historical Society, at University College, London. 
However, Marsden achieved more lasting fame as an active propagator of the Gospels in Australia and New Zealand. He had come into contact with several Maori while in Port Jackson, and was instrumental in the establishment of a mission in New Zealand during the first decades of the nineteenth century. By 1826, he had already been on four visits to the country in support of the rapidly-growing Church of England mission there. His fifth excursion was in early 1827, roughly around the time Earle was in Illawarra. Marsden's much-publicised interest in the country, and Earle's occasional sightings of Maori in Sydney, was probably enough to arouse Earle's curiosity in New Zealand, maybe even to the point where he might visit it one day to delve into yet another unknown territory and record it in paint.

However, it seems that while Earle was primed for further adventure and exploration by October 1827, New Zealand was not his first choice as the location for this to occur. Instead, he had planned to accompany an expedition into the centre of Australia, led by a Captain Street. These arrangements were scuttled, though, as the newly established Sydney newspaper The Monitor reported:

Mr. Earle being disappointed in his wish to journey into the interior of New Holland, (the contemplated expedition under Captain Street being postponed) has sailed in the Governor Macquarie for New Zealand; where he purposes staying a few weeks, to add to his already valuable collection. We regret that the expedition above mentioned has been given up; not only as procrastinating of the advancement of geographical knowledge, but as depriving the public of Mr. Earle's professional services in a journey of discovery. All the discoveries of the interior of Africa and America, have been incomplete from the absence of Artists; the miserable sketches of the travellers being utterly inadequate to a just representation; in a future expedition into the interior of this country, there will doubtless be no Artist here; or, if there be one, the chances are, he will be wanting either in inclination or spirit for the undertaking. Among other objects, Mr. Earle contemplates a Panorama of the Bay Islands [sic]. He has a new field open to his talents in New Zealand, 
and we wish him success. Mr. Shand accompanies Mr. Earle.

A detachment of the Wesleyan Mission also take their passage in the Governor Macquarie for New Zealand. $^{2}$

Australia's loss, as far as the writer of this article was concerned, would obviously be New Zealand's gain. But what is also evident from this extract is that in addition to being an accomplished artist, Earle possessed two other (arguably equally) important facilities for members of his profession: he was an effective self-publicist and a skilled entrepreneur. Over two years of painting and promoting his works in the colony saw him leaving Australia - supposedly for a 'few weeks' - with his reputation consequently at the highest point it had been in his career to date.

Earle's New Zealand expedition was fully documented by the artist, and is the final portion of his life for which there is an abundance of detail. Furthermore, his contact with other literate Europeans in New Zealand resulted in his name appearing in their journals and letters as well, thus providing what is the most rounded view of a period Earle's life that is possible to be reconstructed from evidence of the time.

On 20 October 1827, the brig Governor Macquarie, with Earle on board, departed Sydney bound for New Zealand, or as Earle more flamboyantly wrote, 'we were wafted into the Great Pacific Ocean'. ${ }^{3}$ On board was the Wesleyan missionary John Hobbs, who had previously run a mission known as Wesleydale at Whangaroa until 'a war which took place amongst the natives totally destroyed their establishment'. ${ }^{4}$ This had occurred in January, and now, ten months later, John and his new wife, Jane, were heading to New Zealand to re-establish their mission, but this time under the protection of Patuone, the Ngati Hao chief who had been instrumental in rescuing the Europeans from Wesleydale in the beginning of the year. ${ }^{5}$

\section{Exploring Hokianga}

The Governor Macquarie entered Hokianga Harbour, ${ }^{6}$ on the west coast of New Zealand's North Island, on the morning 
of 30 October. ${ }^{7}$ As soon as the ship neared the shore, a small flotilla of canoes approached it - with its Maori paddlers racing to get on board the ship and thereby be able to trade the choicest goods with the crew. This was Earle's first encounter with a large group of Maori:

I had heard a great deal respecting the splendid race of men I was going to visit, and the few specimens I had occasionally met with at Sydney so much pleased me, that I was extremely anxious to see a number of them together, to judge whether (as a nation) they were finer in their proportions than the English, or whether it was mere accident that brought some of their tallest and finest proportioned men before me. I examined these savages, as they crowded round our decks, with the critical eye of an artist; they were generally taller and larger men than ourselves; those of middle height were broad-chested and muscular, and their limbs as sinewy as though they had been occupied all their lives in laborious employments....The first thing which struck me forcibly was, that each of these savages was armed with a good musket, and most of them had also a cartouch box buckled round their waists, filled with ball cartridges, and those who had fired their pieces from the canoes, carefully cleaned the pans, covered the locks over with a piece of dry rag, and put them in a secure place in their canoes. Every person who has read Captain Cook's account of the natives of New Zealand, would be astonished at the change which has taken place since his time, when the firing a single musket would have terrified a whole village. ${ }^{8}$

From being at the centre of cultural life in Sydney, Earle had thrust himself into the fringes of a substantially different culture. ${ }^{9}$

The following day, Earle went on shore and made a cursory inspection of the local village which a few Europeans had made their home. He was disappointed with the rough collection of huts that constituted the small settlement. There were weeds everywhere, and some of the more unkempt buildings were almost completely overgrown with wild plants. Still though, he was here, and so he took out his paper and 
paints, and produced a watercolour of a scene of the Hokianga Harbour. As with some of his previous works, in View of the village of Parcuneigh and the entrance of the E-O-Ke-Angha River, New Zealand, ${ }^{10}$ Earle placed himself in the picture - this time, in the centre of the foreground, but with his back to the viewer, while a Maori standing next to him with an outstretched hand apparently points out something about the area to the inquisitive artist. To the left are a few huts that are in much better condition than he described in his Narrative, and at the entrance of one of these small buildings, two Maori women are seated.

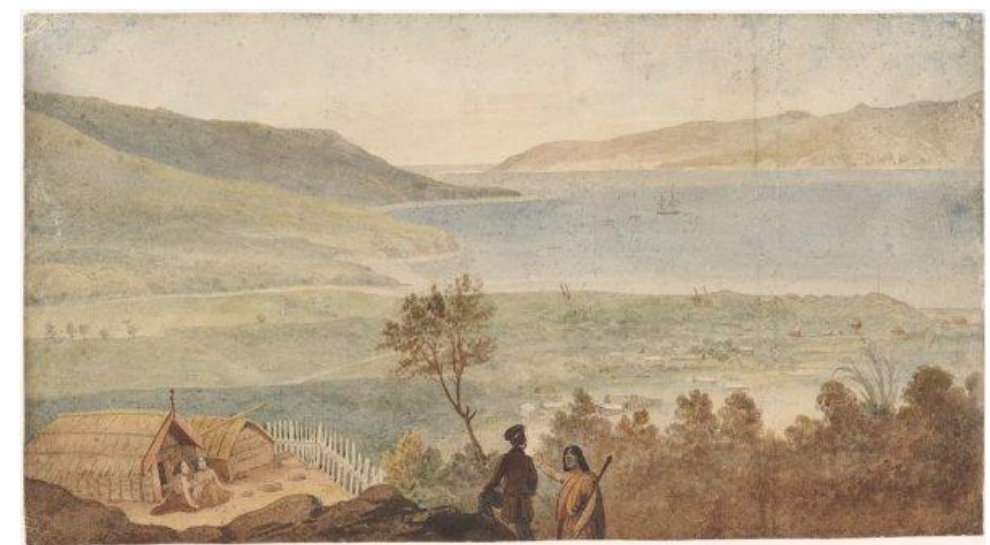

\section{Augustus Earle, View of the village of Parcuneigh and the entrance of the E-O-Ke-Angha River, New Zealand}

This sanitised vista, in which the native population was portrayed as being either helpful or docile, also belied Earle's horror at one feature of Maori culture that he encountered probably on the same day: 'I had not rambled far', he wrote that evening, 'before I witnessed a scene which forcibly reminded me of the savage country in which I then was; and the great alteration of character and customs a few days' sail will make. The sight to me so appalling was, that of the remains of a human body which had been roasted, and a number of hogs and dogs were snarling and feasting upon it! I was more shocked than surprised, for I had been informed of 
the character of the New Zealanders long before my arrival amongst them; still the coming suddenly and unexpectedly upon a sight like this completely sickened me of rambling, at least for that day'.11

Earle was clearly troubled from witnessing signs of this atrocity, and conferred with a local trader, Samuel Butler (who had previously been a missionary but was dismissed for alleged involvement in scandalous behaviour). ${ }^{12}$ Butler explained how the victim had been a boy who had been instructed to look after a garden but who had neglected to do so and so was killed and made into a feast. The matter was more uncomfortable for Earle because he discovered that the perpetrator of the killing and cooking of this boy was among the party that was helping the passengers of the Governor Macquarie to return to the ship, across the mud flats of the harbour. Earle knew that discretion would be the better part of valour, and therefore 'made sure not to shock the feelings of the females, by letting them know the tragedy so lately acted in the village, or horrify them by telling them that one of their carriers was the murderer! It would have been difficult to have made them believe that such a noble looking and goodnatured fellow had so lately imbrued his hands in the blood of a fellow creature!'13

For the next few days, Earle and his party were inundated with visiting Maori - some keen to trade but more just curious to see Europeans in a place where few white people had been. In between the times when he was receiving these guests, Earle managed to explore the area, and was impressed with the 'frugality and industry of these savages'. The ordered plantations of hundreds of acres that he saw being tended to by hard-working Maori - led by industrious chiefs - he found 'truly astonishing'. ${ }^{14}$

One aspect of the way in which Maori managed the land that particularly interested the artist was the application of the principle of tapu (Earle spelt this 'taboo'), which rendered certain areas sacred, and which served as an effective prohibition against trespassing: The New Zealanders have established here a wise custom, which prevents a great deal of waste and confusion, and generally preserves to the planter a good crop, in return for the trouble of sowing; namely, as soon 
as the ground is finished, and the seed sown, it is tabooed, that is, rendered sacred, by men appointed for that service, and it is death to trample over or disturb any part of this consecrated ground. The wisdom and utility of this regulation must be obvious to every one'. The only problem Earle found with tapu was the inconvenience it caused visitors such as himself who were intent on rambling across the country. He noted that unless people used the greatest caution and procured a Maori guide, they could get themselves into a grim predicament. This was the voice of experience. Earle had accidentally breached tapu within the first week of his arrival in New Zealand - something he described with great relief when he reflected how he escaped any serious consequences:

We were ascending a hill, for the purpose of inspecting a New Zealand fortification on the summit, when a little boy joined our party, either out of curiosity, or in hopes of getting a fish-hook from us,- a thing the natives are continually asking for; but as we had a man with us who spoke the language fluently, we did not much regard the boy's guidance, though to us it speedily became of great importance. We were taking a short cut, to make a quick ascent to the top of the hill, when the little fellow uttered a cry of horror. Our interpreter asked him what he meant, when he pointed his finger forward, and told him to look, for the ground was tabooed. We did as he desired us, but beheld nothing particular, till he showed us, in one of the trees, among the branches, a large bunch of something, but we could not make out what it was. This, he told us, was the body of a chief, then undergoing the process of decomposition, previous to interment, which process is witnessed by men appointed for that purpose, who alone are permitted to approach the spot. The ground all round is tabooed, so that, had it not been for the interference of our young guide, we should certainly have been placed in a most distressing situation; and it is a question if our ignorance of their customs would have been considered a sufficient excuse for our offence. ${ }^{15}$ 
The picture Earle chose to accompany this portion of his Narrative when it was published was A tabood store house, New Zealand. 16

It appears in his book as an engraving, but was based on a watercolour he produced either in New Zealand, or very shortly after his return to Sydney. His description of the subject of the picture shows how impressed he was with Maori art, although he still regarded it as primitive, and lacking in the sort of theoretical background with which he was familiar: 'Their storehouses are generally placed upon poles, a few feet from the ground, and tabooed or consecrated. Great taste and ingenuity are displayed in carving and ornamenting these depositories. I made drawings from several of them, which were entirely covered with carving; and some good attempts at groups of figures, as large as life, plainly showed the dawning of the art of sculpture amongst them. Many of the attempts of the New Zealanders in that art are quite as good, if not better, than various specimens I have seen of the first efforts of the early Egyptians'. ${ }^{17}$

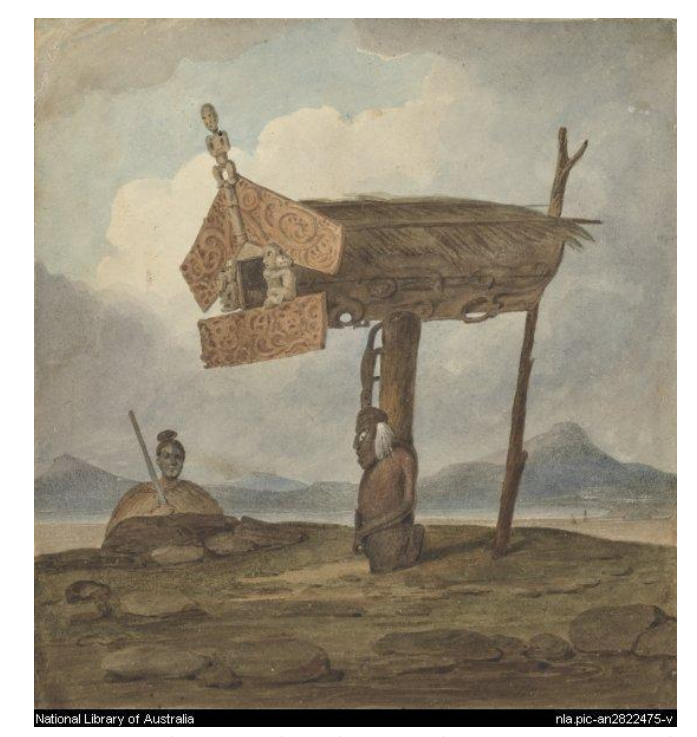

Augustus Earle, A tabood store house, New Zealand. 
Earle could not help but add a slightly quizzical element to this scene, however, by having a warrior peering just above ground level, looking at the carved figure at the base of the pole which supported the storehouse. The warrior and the carved man are of similar dimensions, and because of the angle that they are portrayed, both have bodies that only go down as far as the waist, while Earle gave the warrior features that make him appear just as wooden as the carving that is staring at him.

A few days later, Earle travelled further up the Hokianga Harbour, and just when it looked as though there was nothing more to see, he came across a thriving port. There, he

beheld, with both surprise and satisfaction, a most unexpected sight; namely, a snug little colony of our own countrymen, comfortably settled and usefully employed in this savage and unexplored country. Some enterprising merchants of Port Jackson have established here a dockyard and a number of sawpits. Several vessels have been laden with timber and spars; one vessel has been built, launched, and sent to sea from this spot; and another of a hundred and fifty tons burthen, was then upon the stocks! On landing at this establishment at E. O. Racky, or, as the Englishmen have called it, "Deptford," I was greatly delighted with the appearance of order, bustle, and industry it presented. Here were storehouses, dwelling-houses, and various offices for the mechanics; and every department seemed as well filled as it could have been in a civilised country. ${ }^{18}$

This was Horeke (both 'E. O. Racky' and sometimes 'Showrackki' in Earle's orthography) - the oldest European settlement in Hokianga and the second oldest of its sort in New Zealand. It was one of the centres of the thriving timber and flax trade, 19 and the success of the entrepreneurial activity carried out in this location soon led to demands that Britain play a more formal role in the country. ${ }^{20}$

Earle produced two watercolours of this industrious site The E.O. Racky or Deptford Dockyard, on the E.O. Keangha River, $N$. Zealand, ${ }^{21}$ and The Showrackki, commonly called 
Deptford Dock Yard, a ship building establishment, belonging to some Sydney merchants in the Shukeangha River, New Zealand. 22

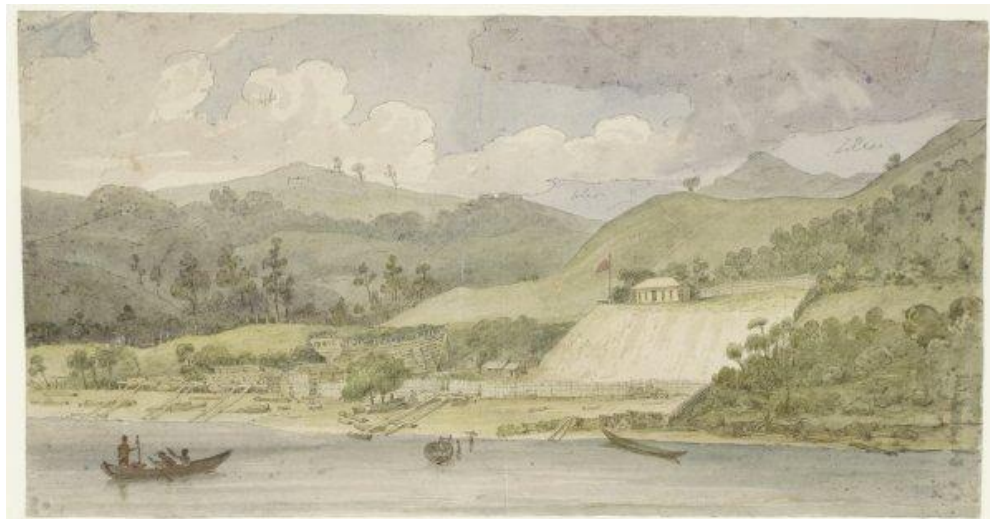

Augustus Earle, The E.O. Racky or Deptford Dockyard, on the E.O. Keangha River, N. Zealand.

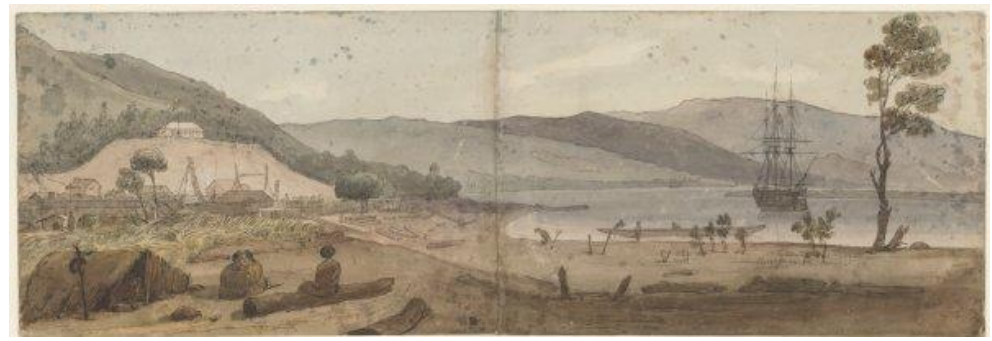

Augustus Earle, The Showrackki, commonly called Deptford Dock Yard, a ship building establishment, belonging to some Sydney merchants in the Shukeangha River, New Zealand.

Neither work stands out for its artistic merit, but both provide a useful survey of the location (one taken from the coast, and the other from the shore). From an historical perspective, therefore, they are of great importance - a rare visual record of one of the oldest permanent European communities in the country. What is odd with both of these paintings, however, is that they reflect nothing of the great activity Earle's described in his Narrative. In fact, they show almost the opposite. In The E.O. Racky or Deptford Dockyard, 
instead of 'bustle', and vessels heavily 'laden with timber and spars', there are just a few canoes languishing in the bay, while on shore, there is no-one present. And instead of the 'storehouses, dwelling-houses, and various offices for the mechanics', there is merely one substantial building on a rise above the shore, and a very small cottage below.

The Showrackki, commonly called Deptford Dock Yard shows marginally more activity taking place, but there is a similar air of lethargy and inactivity hanging over the scene. A ship is anchored in the harbour, while on shore, two Maori sit outside a hut. Again, there is no real indication that this was one of the major centres of the country's trade.

The contradiction between Earle's written description and his images of Horeke is puzzling. He went on to write in his Narrative, for example, about the pleasure that Maori seemed to take in observing the British tradesmen working there, and yet no such record of this appears in his two works of the settlement. And when discussing the civilising effects on Maori of the work being carried out at this location, Earle argued that

Nothing can more completely show the importance of the useful arts than a dockyard. In it are practised nearly all the mechanical trades; and these present to the busy enquiring mind of a New Zealander a practical encyclopaedia of knowledge. When he [a Maori] sees the combined exertions of the smith and carpenter create so huge a fabric as a ship, his mind is filled with wonder and delight; and when he witnesses the moulding of iron at the anvil, it excites his astonishment and emulation. The people of the dockyard informed me, that although it was constantly crowded with natives, scarcely any thing had ever been stolen, and all the chiefs in the neighbourhood took so great an interest in the work, that any annoyance offered to those employed would immediately be revenged as a personal affront. ${ }^{23}$

So where are the constant crowds of natives? Why did Earle allow such a wide gulf to open up between his written and visual representations of the same site? No definite answer can be given for such irregularities between his written 
and visual portrayals of the location, but it is possible that the original paintings of Horeke, which Earle produced on-site, and at the same time as he wrote these descriptions, were destroyed by fire when he was in Kororareka (in the Bay of Islands) and so he may have had to reproduce versions of these images either later during his stay in New Zealand, or even once he was back in Australia, with consequently less attention paid to the accuracy of the scene than would have appeared in the originals. ${ }^{24}$

\section{Journey to the Bay of Islands}

Eager to explore more of the island, and in particular, the major European settlement at Kororareka on the east coast, Earle and his friend, a Mr. Shand (who was accompanying him on this journey but about whom Earle was suspiciously quite throughout his Narrative), decided to travel overland to the Bay of Islands. They were joined by a chief who was also keen to walk the approximately fifty kilometres to the other coast, and with him came two slaves who assisted with carrying the luggage.

The first stage of the journey was a short stint in a canoe to the upper reaches of the Hokianga Harbour, and then along a river that quickly thinned out, leaving the party leaving to undertake the rest of the trip on foot. Along the way, the signs of European habitation became ever more slight, while the number of Maori settlements grew more numerous. Away from these small villages, however, the going was tough for Earle and his party. Portions of the forest were so thick as to be almost impenetrable, while the area was intersected with innumerable small streams which further hindered their progress.

In the midst of this forbidding wilderness, Earle and his fellow travellers entered a clearing, where they found a group of Maori with their chief, Patuone. ${ }^{25}$ Patuone was a Nga Puhi leader with an august pedigree, and was probably aged between thirty and forty years at this time. On seeing these strangers, he welcomed them and invited them to stay the night at his village, which was just a few kilometres away. As the party approached Patuone's village, Earle saw a scene that he felt was worthy to be painted: 'As the village lay upon the 
opposite shore from that on which we arrived, we sat some time under the shelter of a large tree, to contemplate its appearance, and to give time to arrange our party for passing the stream, and also for my making a sketch. The red glare of the setting sun, just touching the top of every object, beautifully illuminated the landscape; and its rays, bursting through the black woods in the back-ground, gave the woods an appearance of being on fire; while a beautiful rainbow, thrown across the sky, tinged the scene with a fairy-land effect'. 26

As Earle noted, he made a sketch of this view, but whether that sketch survived to enable him to use it as the direct basis of the engraving of this vista that was later published in London, or whether it shared what was possibly the same fiery fate as The E.O. Racky or Deptford Dockyard and The Showrackki, commonly called Deptford Dock Yard is unknown. However, like both of these pictures, Earle's Native village and cowdie $^{27}$ (which was presumably the view he saw and sketched on the approach to Patuone's village), fails to match the vivid descriptions of the vista he wrote of in his Narrative.

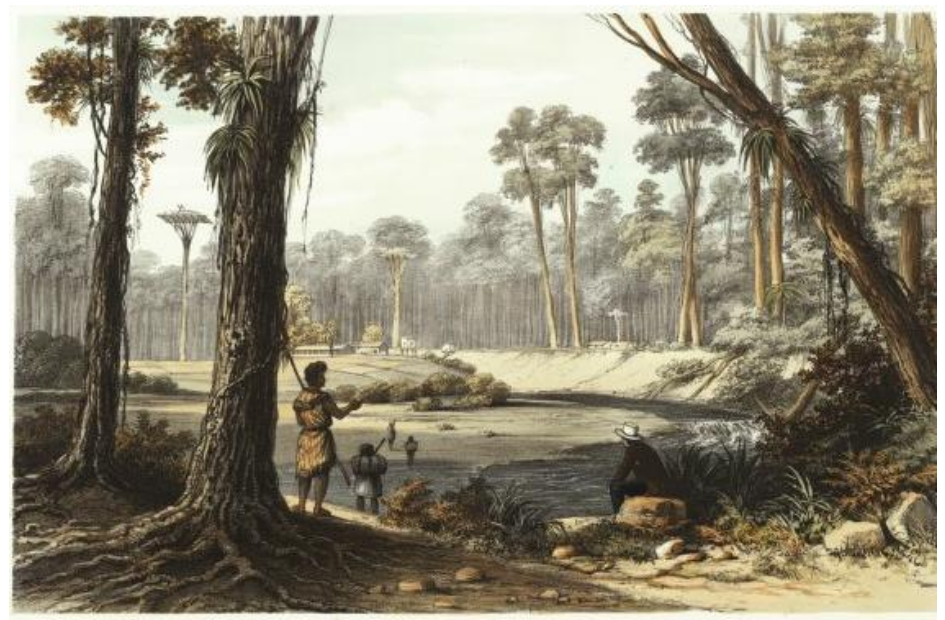

Augustus Earle, Native village and cowdie. 
Instead, it is a fairly routine depiction of a bush scene, this time with a 'native village' and a river running around part of it. Earle's idiosyncratic elements are repeated in this work: large trees on the left and right of the picture, framing the main scene; a person with their back partially facing the viewer and pointing to the direction the group will be heading to; a procession of people walking to a destination in the distance; and a person sitting on a rock with their back to the viewer, looking into the middle distance, and in doing so, encouraging the viewer to focus on the village which is at the centre of the picture. This person is probably Earle, ${ }^{28}$ and like several of his previous works, he was making himself part of the scene by stamping his presence on the territory he was visiting.

This mundane portrayal of Earle's arrival at the village - in complete contrast to the colourful description he wrote of this location - suggests that the picture was created well after Earle had left the area, and when his memory of the romantic elements that he wrote of had faded. The fact that the kauri trees in the picture have a slight appearance of Australian gum trees could even be the basis for an argument that Earle created this scene once he had returned to Australia, when his recollection of the precise form of kauri trees would have been weaker.

Following a night at Patuone's village, Earle and his party continued with their journey the next day, although they were now finding the forest even more dense and difficult to walk through. After about four hours of tramping through the entanglement of the bush, they came to a summit from which they could see Kerikeri and the Bay of Islands in the distance. The scenery captivated Earle, but so too did the social circumstances of the region, in particular, the juxtaposition of Maori and Europeans, as he noted:

Occasionally we met groups of naked men, trotting along under immense loads, and screaming their barbarous songs of recognition; sometimes we beheld an uncouthly carved figure, daubed over with red ochre, and fixed in the ground, to give notice that one side of the road was tabooed. An extraordinary contrast was 
now presented to our view, for we came suddenly in front of a complete little English village. Wreaths of white smoke were rising from the chimneys, of neat weather-boarded houses. The glazed windows reflected the brilliant glow from the rays of the setting sun, while herds of fat cattle were winding down the hills, lowing as they leisurely bent their steps towards the farm-yard. It is impossible for me to describe what I felt on contemplating a scene so similar to those I had left behind me. ${ }^{29}$

Earle was missing 'civilisation', and despite the years he had spent travelling around much of the world, the image of an English country cottage - even though it was at the other end of the earth - was enough to trigger memories of 'home'.

\section{'No Touch of Human Sympathy'}

As soon as they saw this village, some of the members of Earle's group began to fire their muskets - a practice that had become customary in New Zealand to forewarn inhabitants of a settlement that visitors were on their way. Earle was excited. At last, he was about to enter what looked like a pastoral paradise. On approaching the outskirts of the village, though, his hopes were rapidly replaced by disappointment:

As the report of our guns had been heard, groups of nondescripts came running out to meet us. I could scarcely tell to what order of beings they belonged; but on their near approach, I found them to be New Zealand youths, who were settled with the missionaries. They were habited in the most uncouth dresses imaginable. These pious men, certainly, have no taste for the picturesque; they had obscured the finest human forms under a seaman's huge clothing. Boys not more than fifteen wore jackets reaching to their knees, and buttoned up to the throat with great black horn buttons, a coarse checked shirt, the collar of which spread half way over their face, their luxuriant, beautiful hair was cut close off, and each head was crammed into a close Scotch bonnet! ${ }^{30}$ 
Putting aside the scruffy appearance of the local Maori, Earle made his way to the house of one of the missionaries. He was fully expectant of a warm welcome, especially as he had a letter of introduction from the Church Missionary Society in Sydney (which suggests at least the possibility that he had been in contact with Marsden before leaving Australia). What followed was an episode that, although almost an aside, when it was published in Earle's 1832 Narrative, caused enormous controversy. The passage might appear relatively innocuous to modern readers, but at the time, it was considered hugely provocative and even malicious:

We were ushered into a house, all cleanliness and comfort, all order, silence, and unsociability. After presenting my letter to a grave-looking personage, it had to undergo a private inspection in an adjoining room, and the result was, an invitation "to stay and take a cup of tea!" All that an abundant farm, and excellent grocer in England could supply, were soon before us. Each person of the mission, as he appeared during our repast, was called aside, and I could hear my own letter read and discussed by them. I could not help thinking (within myself) whether this was a way to receive a countryman at the Antipodes! No smile beamed upon their countenance; there were no enquiries after news; in short, there was no touch of human sympathy, such as we "of the world" feel at receiving an Englishman under our roof in such a savage country as this!

The chubby children who peeped at us from all corners, and the very hearty appearance of their parents, plainly evidenced that theirs was an excellent and thriving trade. We had a cold invitation to stay all night; but this the number of our party entirely precluded; so they lent us their boat to convey us to the Bay of Islands, a distance of about twenty-five miles. ${ }^{31}$

In an 1833 edition of the Edinburgh Review, Earle was lambasted for these cursory observations. Near the beginning of the article, the unnamed author described the artist's writings and observations generally as being variously 'superficial', 'defective', and 'erroneous'.32 These condemnatory assessments of his Narrative were a prelude to 
a more detailed criticism of his representation of the missionaries he came across: The Missionaries of the Church of England Society...in 1814, obtained a grant of 200 acres of land, and have since formed several other settlements. They find, however, by no means the same favour in the eyes of $\mathrm{Mr}$ Earle, who never mentions them but in terms of complaint and sarcasm. Without waiting for any answer from them, we can easily perceive that this alienation arose solely from an entire opposition of temper and habits. They treated him, it appears, in a polite and friendly manner, but coldly, - shunning any approach towards intimacy'. Earle's response was considered an overreaction. After all, as the writer of this article continued, 'All men have the right to choose their associates; and allowing fully our author's [Earle's] merits, he is plainly not that sedate and sober person who was likely to gain their confidence'. To this was added a crude attempt to impugn Earle's own moral integrity: 'He [Earle] appeared also in intimate association with the whale-fishing crews; whom the missionaries accused, and apparently with justice, as counteracting, by their example, the moral instructions bestowed upon the islanders. The different views of the parties may be illustrated by our author's narrative of a Christmas excursion. He and several of his companions repaired to the mission-house, with the materials of a copious bowl of punch, and the determination to have a jovial celebration of the day. As they approached, however, they became most indignant to find the windows shut, and all access denied; and when, instead of the proposed merry meeting, the missionaries soon after came out to preach'.33

There were other comments directed at Earle - one suggesting that his very brief stay in the country had not allowed him sufficient time to acquire a close knowledge of the societies that lived there, and another citing cases of his alleged hypocrisy - but by this stage, enough opprobrium had been hurled at him that at least some would have stuck. Earle's dismissive views of some ethnic groups were looked over as little more than amateur anthropological observations, but when it came to Anglican missionaries, it seems that even the slightest, off-the-cuff comment could prompt angry 
responses from those sympathetic to the Church of England's evangelical activities.

William Williams, the missionary and brother of Henry Williams (who was head of the Anglican Church in New Zealand) could not help but snipe at Earle after hearing reports of his criticism of his fellow Church of England missionaries. In a letter he wrote to the Church Missionary Society in London following the publication of Earle's Narrative, Williams justified the cool treatment the artist had received as being the result of his moral laxity. 'Mr. Earle I am told was living in connexion with a native woman', ${ }^{34}$ was Williams' gossipy response, as if the standoffish behaviour of the Anglicans towards Earle was something the artist had brought on himself.

The harshest criticism the artist faced for his remarks about the missionaries, however, appeared in an 1832 edition of The Eclectic Review. Earle was attacked personally, with the author of this missive starting off by claiming Earle had been guilty of living with loose morals, and arguing that: 'From a person whose life has been thus spent, it would be unreasonable to expect any other than a sailor's narrative; nor ought it to excite surprise to find that the moral and religious notions of the Author [Earle] are not characterized by elevation or purity. As an artist, he naturally prefers the picturesque wildness of savage life to the tameness of civilization, and abhors to see 'the finest human forms obscured under a seaman's huge clothing'. 35

There was also justification offered for the terse reaction Earle had received when visiting one group of missionaries: 'The Missionaries might possibly have good reason for giving but a grave welcome to 'the party', in company with whom it appears that Mr. Earle introduced himself; and they seem to have formed a correct estimate of the uncongenial character of their guest.... We cannot conceive of any more undesirable acquaintance to pious men so circumstanced, than a party of licentious sailors, to whom the efforts of all missionaries are the subject of coarse ridicule, and whose intercourse with the natives they have so just reason to dread, as tending to counteract all their instructions'. ${ }^{36}$ In general, the outlook of the main Protestant Church missionaries in New Zealand at 
this time was as 'an oasis of Anglican civilisation in the Maori wilderness'. ${ }^{37}$ This may account in part for their standoffishness on occasion.

Yet, there were times when Earle commented favourably on the work that the missionaries were doing (if not on their demeanour when undertaking this work), and which his critics generally chose to ignore. One such case involved the treatment of a former Maori slave. When he was paying a visit to a mission station in the Bay of Islands (he did not specify which, but it was almost certainly an Anglican one), he described how he 'noticed a remarkably fine native woman attending as a servant. She was respectably dressed, and in every respect (except complexion) she was similar to an European. She spoke English fluently'. Earle told the missionaries there how impressed he was with the progress towards civilisation that she was evincing, and was informed by them that she had been one of Hongi's slaves, 'and that about a year previous he had lost one of his sons, and had determined to sacrifice this poor girl as an atonement. She was actually bound for the purpose, and nothing but the strong interference of the whole of the missionary society here could have saved her life. They exerted themselves greatly, and preserved her; and she had proved a faithful and valuable servant'. 38

In another instance of Earle highlighting the success of the missionaries' work among local Maori, he observed how, since he had been in New Zealand, most Maori had become firm adherents of the commandment to keep the Sabbath holy. He observed how they were keen to 'refrain from all kinds of work on the Sabbath; to shave, and dress themselves in their best habiliments; and if any of the missionaries came over, they went forth to meet them, and hear divine service. Several of the natives generally assembled and witnessed the ceremony; and as they observed it came every seventh day, they called it "The white taboo'd day, when the packeahs (or white men) put on clean clothes, and leave off work;" and, strange to say, the natives also abstained from working on that day. Nothing could induce them to the contrary; not that we wished to persuade them to work, but merely endeavoured so to do to ascertain the strength of their politeness. Not a bit of work 
would they do upon a Sunday, although it was a critical time with them'. 39 These types of comments and observations were praise where praise was due, but for the missionaries who had been stung by what felt like a grossly unfair criticism of them, it was insufficient to undo the perceived harm Earle had inflicted.

Later on in the Narrative, Earle's matter-of-fact view of another aspect of missionary work gave fresh reason for members of the Anglican Church to condemn him and his book. He recorded how on one Sunday afternoon, when some of the local missionaries held a church service, 'the minister endeavoured to explain the sacred mysteries of our religion to a number of the chiefs who were present. They listened attentively to all he said, and expressed no doubts as to its truth, only remarking that "as all these wonderful circumstances happened only in the country of the white men, the great Spirit expected the white men only to believe them." The missionary then began to expatiate on the torments of hell, at which some of them seemed horrified, but others said, "they were quite sure such a place could only be made for the white faces, for they had no men half wicked enough in New Zealand to be sent there;" but when the reverend gentleman added with vehemence that "all men" would be condemned' and this was the point that irritated many of those who read Earle's Narrative - 'the savages all burst into a loud laugh, declaring "they would have nothing to do with a God who delighted in such cruelties; and then (as a matter of right) hoped the missionary would give them each a blanket for having taken the trouble of listening to him so patiently." 40

The artist was also critical of how some missionaries purportedly prevented the indigenous inhabitants in the communities they settled in from learning English. According to Earle, these evangelists achieved this feat by learning Maori as soon as possible. ${ }^{41}$ However, this was an unfair item on Earle's register of protests against the missionaries. Earle was mistaking the eagerness of the missionaries to communicate with Maori by speaking to them in their own language with some darker intent to keep them from acquiring English. It was a misreading of the situation, and shows how Earle could occasionally be quick to estimate circumstances and judge 
those involved, even if he did not have the full facts at his disposal.

\section{'Both Useless and Dangerous'}

After what Earle felt was a frosty reception by the missionaries in this isolated village, he and his group decided to leave (ironically, with the assistance of a boat that these missionaries lent him). They boarded their small vessel to travel down one of the tributaries of the Kerikeri River towards the Bay of Islands, which Earle estimated to be about forty kilometres away.

Such was the frustration with the attitudes of these missionaries that the party opted to leave immediately, even though it was getting dark. To make matters worse, the weather began to deteriorate, and shortly after sunset, a storm lashed the region. The canoe was too crowded, and the passage down the rock-filled river was 'disagreeable and dangerous'. Around midnight, they arrived at the Bay of Islands, and were given shelter in the hut belonging to a local English settler.

The next morning was fine and warm. The distasteful experience of the previous day was forgotten, and Earle's artistic pulse began to beat again. Coming out from his hut at daybreak, he looked around the area, and then jotted a note in his Narrative: 'Bay of Islands is surrounded by lofty and picturesque hills, and is secured from all winds. It is full of lovely coves, and a safe anchorage is to be found, nearly all over it; added to this, a number of navigable rivers are for ever emptying themselves into the Bay, which is spotted with innumerable romantic islands all covered with perpetual verdure'. ${ }^{42}$ In this vicinity, Earle quickly built up an impression of the range of inhabitants who lived there.

By now, trade had been conducted in this region between Maori and European for at least two decades, and according to Earle, the effect of these encounters on Maori was considerable, but on the whole for the better. "They have not only lost a portion of their ferocity, but also much of their native simplicity of character', he wrote, 'which, in all parts of the world, is so highly interesting a study for the traveller. Their constant intercourse with whalers, who are generally 
low, unpolished men, leaves behind it a tinge of vulgarity, of which the native women retain the largest portion. In many instances, they quite spoil their good looks, by half adopting the European costume'. ${ }^{43}$

But if Earle was slightly ambivalent about the plight of Maori, he was much more certain about the calibre of some of his countrymen who had chosen to live in the region. Many, he concluded were 'of so doubtful a character that it would be difficult to guess to what order of society they belonged previous to their being transplanted amongst these savages', and while there were some of the 'hardy sons of Britain' present in the Bay, there was another class of Europeans - the so-called 'Beach-Rangers' - whom he considered to be 'both useless and dangerous', and whom he believed lowered 'the character of the white people in the estimation of the natives'. These were mainly deserters who were too lazy to work, and so often resorted to petty crimes and living off the land as a means of maintaining their existence.

Finally, Earle described a third category of people living in the Bay of Islands. These were men 'whose downcast and sneaking looks proclaim them to be runaway convicts from New South Wales. These unhappy men are treated with derision and contempt by all classes; and the New Zealanders, being perfectly aware of their state of degradation, refuse all intercourse with them. They are idle, unprincipled, and vicious in the extreme, and are much feared in the Bay of Islands; for when by any means they obtain liquor, they prove themselves most dangerous neighbours'. ${ }^{4}$

\section{'Their Coldness and Inhospitality'}

By chance, an 'intimate' friend of Earle's - Captain Duke, of the whaler, The Sisters - was recuperating in the Bay of Islands following a bout of illness. Earle and Shand stayed with Duke in his hut, and learned from the Captain which types of people in the Bay of Islands were best to avoid. And by a further chance, in the adjoining hut was the chief Te Whareumu (whom Earle called 'Shulitea', as a variant of the chief's other name, Te Huritea, or 'King George', which was his anglicised name). 45 Te Whareumu was a highly-ranked chief of the Ngati Manu tribe of the Bay of Islands, ${ }^{46}$ and not only 
showed great friendliness to Earle and Shand, but also gave them a sense that they had a level of protection that otherwise would have been unavailable to them.

Earle was impressed by the reputation for protecting the welfare of Europeans that Te Whareumu had in the region, but was puzzled why it was that after years of contact with these Europeans, there seemed to have been few changes in Maori culture or lifestyles. He lamented that Their huts are of the same diminutive proportions as described by Captain Cook; their clothing and mats, their canoes and paddles, are precisely the same as when that navigator described them. When they can obtain English tools, they use them in preference to their own; still their work is not better done', and added acerbically but nonetheless accurately that 'The only material change that has taken place is in their mode of warfare'. 47

Earle did a watercolour of Te Whareumu, which is one of the very few paintings of any Maori chiefs made during this period. ${ }^{48}$ King George, N. Zealand costume ${ }^{49}$ shows the chief seated on the ground, taiaha (fighting staff) in hand, and dressed in a traditional korowai (cloak).

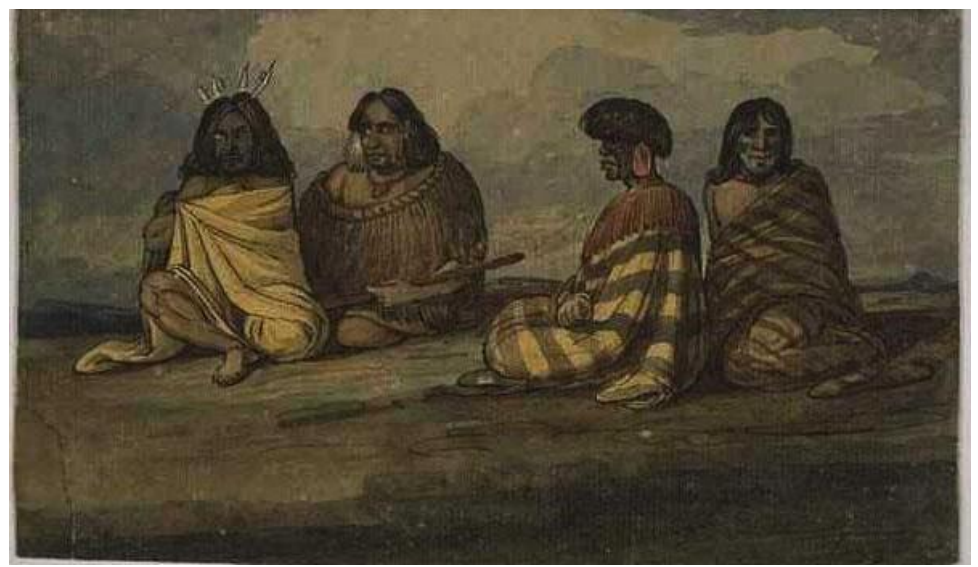

Augustus Earle, King George, N. Zealand costume 
With him are three women - probably his wives - all of whom are clad in blankets, with traces of more traditional garb underneath. The juxtaposition of traditional and modern clothing could be just coincidence, although this may easily be an oblique reference to the popularity of Maori women prostitutes among European sailors in the Bay of Islands at this time - for which services the women were sometimes paid in goods such as blankets. 50

Another painting of the chief by Earle has Te Whareumu seated with two women and a child. Their drab brown clothing almost melds in with the brown of the ground on which they are seated. This work - The residence of Shulitea chief of Kororadika Bay of Islands, New Zealand ${ }^{51}$ - for all its grim tones, probably is as accurate a representation of Maori village life in Northland in the 1820 s as exists anywhere.

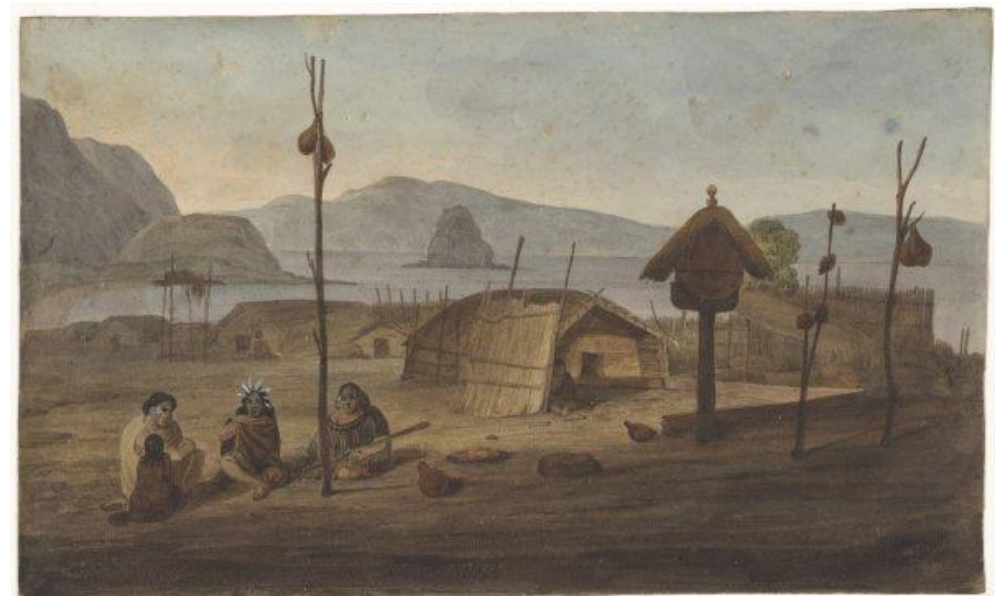

Augustus Earle, The residence of Shulitea chief of Kororadika Bay of Islands, New Zealand.

Earle avoided glamorising the scene, or yielding to any temptation to convert it into that befitting a Noble Savage. Instead, he depicted Te Whareumu's residence as he saw it. There are bags of food hung from tall sticks, designed to keep them out of reach of animal pests, while on the ground are scattered what appear to be calabashes - a common feature 
for communities that were positioned (like this one) on hills where there was usually no water supply immediately at hand.

Earle casts a beam of light running across the centre of the picture, with Te Whareumu's hut illuminated by it. Most of the other huts and the bric-a-brac of the village, as well as the subject of the painting, are in the shade. This employment of shade, which Earle had also used in a similar way in some of the works he produced while in Australia, serves as a metaphor for the people or society represented in the picture being uncivilised, or (literally) less enlightened. In both a figurative and literal sense in The residence of Shulitea chief, the sun is already setting, and for a contemporary English viewer, the scene craved the intervention of Europeans to bring at least the material benefits that are plainly missing in this image.

A few days after arriving at Kororareka, Earle crossed over the bay to what was then known as Marsden Vale (later to be renamed Paihia). Situated on the beach was an Anglican missionary settlement which Earle had decided to visit in order to present the letter of introduction he had brought with him from Australia. Initially, he had thought it would have been appropriate to show the letter to the missionary colony he came across while travelling from Hokianga, but the rigid greeting he had received there left him with little inclination to further his relations with them. Maybe the Bay of Islands missionaries would be warmer and more open in their welcome?

Despite the magnificent surrounds, 52 though, Earle's impression of the missionary settlement was soured when he again encountered rudeness from a group of Anglican evangelists. That evening, he wrote in his Narrative: 'They [the missionaries in Paihia] very soon gave us to understand they did not wish for our acquaintance, and their coldness and inhospitality (I must acknowledge) created in my mind a thorough dislike to them. The object of the mission, as it was first planned, might have been attained, and might have proved highly beneficial to the New Zealanders; but as it is now conducted, no good result can be expected from it. Any man of common sense must agree with me, that a savage can receive but little benefit from having the abstruse points of the 
Gospel preached to him, if his mind is not prepared to receive them. This is the plan adopted here; and nothing will convince these enthusiasts that it is wrong, or induce them to change it for one more agreeable to the dictates of reason'.53 This was a fair observation from a man who had been twice shunned by these preachers of the Gospels. And although such comments were later seized upon as supposed proof of Earle's hostility towards Christianity, it would be just as fair to interpret them as evidence of a man for whom the message of Christianity was too valuable to be put in the hands of such unpleasant people.

Earle asked around to find out more about these missionaries, and noted with a sneer that 'the greater part of them were hardy mechanics (not well-educated clergymen), whom the benevolent and well-intentioned people of England had sent out in order to teach the natives the importance of different trades, - a most judicious arrangement, and which ought to be the foundation of all missions'. ${ }^{54}$ The problem was that this ambitious idea failed to materialise as Church officials in London had anticipated. Instead, once these mechanic-missionaries had built houses for themselves and established maybe a farm or a blacksmith, then commenced the 'easy task of preaching'. Earle cast his eyes over the scene at Paihia, and deduced the manner in which these missionaries operated and the damage they caused: "They collect a few ragged urchins of natives, whom they teach to read and write their own language - the English tongue being forbidden; and when these children return to their families, they are despised by them, as being effeminate and useless. I once saw a sturdy blacksmith in the prime of life, sitting in the midst of a group of savages, attempting to expound to them the mysteries of our holy redemption - perplexing his own brains, as well as those of his auditors, with the most incomprehensible and absurd opinions. How much better would he have been employed in teaching them how to weld a piece of iron, or to make a nail!'55

This disagreeable experience with the missionaries was no chance clash of personalities, or the product of some misunderstanding. When the artist returned later that day to Kororareka, some of his Maori friends there laughed at him. 
Evidently, they had warned Earle of the reaction he was likely to receive before he had even left that morning. Earle could not help but appreciate the contrast between the coldness of the missionaries in Paihia, and the warm welcome he received from his Maori associates when he returned to Kororareka. He decided at that point never to visit the missionaries again while he was in New Zealand. However, when Henry Williams was collecting money for the Bethel Union Society (a Sydneybased mission which worked mainly with sailors) he noted in his diary for Monday 10 December 1827 that he received a one pound donation from Earle for the mission. 56 Evidently, the artist was not completely opposed to the work of these missionaries, and had nothing adverse to say in his Narrative about Williams.

In the gossipy community of Kororareka, news of Earle's encounters with the Anglicans spread quickly, aided by the artist's readiness to put his thoughts to paper. One such record was obtained by the press in Sydney, and duly reported on, giving an insight into how Earle found various missionaries, and a possible explanation for the treatment he received:

Mr. Earle describes the Wesleyan Missionaries as abounding in hospitality, and the Church Missionaries as abounding in the opposite qualities. A sick captain of a ship who solicited the use of one of their skillens to lay his head out of the sun and wind was refused. We apprehend that the too free intercourse between the masters of vessels and the young women of New Zealand, has soured the tempers of these holy men. If however, hospitality, kindness, and long-suffering, will not cure the shipmen of fornication, we are sure sourness and frowns and spiritual hauteur will not. The Church-folks however, acted with the precaution which to Government people, is instinctive, whether they be religious or profane. They forced a smile of complacency into their countenances, until they had ascertained that Mr. Earle and his friend were not connected with the Government; but the moment they became satisfied they were private gentlemen travelling, the one professionally, and the other for health, their faces assumed their natural acerbity. ${ }^{57}$ 
Maybe there was something to this. Maybe the missionaries had become reclusive, feeling that they were an island of moral righteousness, surrounded by a sea of sin, and thus had grown to become instinctively averse to dealing with Europeans. However, as far as Earle was concerned, he no longer had any inclination whatsoever to deal with the representatives of the Anglican Church in New Zealand, and did not write about them again.

Henry William's final word on the matter came about six years later, when Earle's book had been published, and a copy of it found its way to New Zealand. Williams' journal relates how he heard about Earle's criticisms in the Narrative, and conveys his opinion of the artist's observations of the New Zealand missionaries: 'Mr Marshall the assistant Surgeon landed, who appears to be a very serious young man. Had the pleasure of his conversation for about two hours. He mentioned that Earl's [sic] narrative had been the general topic of conversation for many weeks, and that they [these arrivals to the Bay of Islands] would scrutinize us with much severity; however as they had shewn a friendly disposition, I felt it needful to call on board as I passed to Paihia. The book lay upon the table. I was asked if I had seen it. I replied that we felt ourselves highly complimented by it, for it established the truth that we were no buyers nor sellers, that each was intent upon the object appointed him; this testimony we felt of much value'.58 Was this a case of Williams turning the other cheek? Possibly, although it is also feasible that the type of missionary behaviour Earle wrote about was familiar to Williams, and at the very least he was not surprised by Earle's observations.

\section{'A Great Natural Genius'}

An article in Sydney's The Monitor newspaper from December 1827 makes a rare mention of a specific painting Earle produced while in New Zealand. The article was based on letters that the newspaper had received from Earle and Shand (Earle knew that he could not afford to let his Sydney market forget about him completely while he was away), and stated that 'After a run of ten days, they [Earle and Shand], arrived at New Zealand, and are highly delighted with the 
country and inhabitants. Among other interesting subjects, Mr. Earle, with his usual industry, hath, as we predicted, completed a Panorama of the Bay of Islands than which we can fancy scarcely any thing more interesting to the good folk of London'.59

The report reeks of Earle's capacity for self-promotion, but is never-the-less useful because it points very closely to a date when this painting was produced - something that is almost impossible to do for the vast majority of Earle's other works. The panorama survives in two forms: a watercolour, painted on location in the Bay of Islands, and a fuller vista reproduced as an engraving by Robert Burford 1838.60

The painted scene - Bay of Islands, New Zealand ${ }^{61}$ portrays a group of around nine Maori seated in the centre foreground, most of whom have their backs to the viewer and are looking out to the bay, where two ships lie anchored.

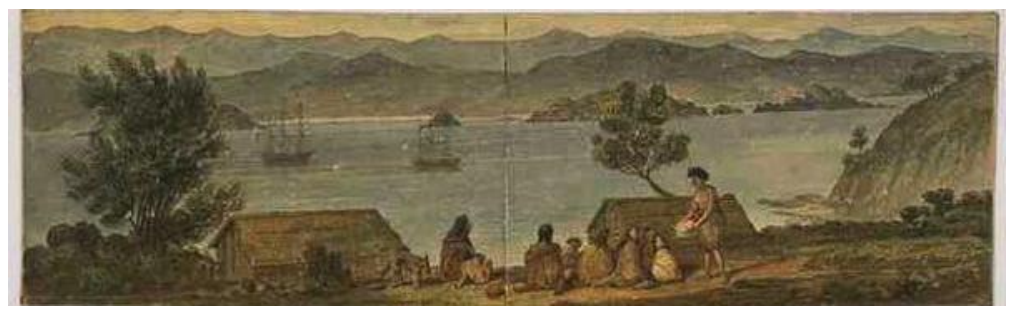

Augustus Earle, Bay of Islands, New Zealand

Ostensibly, it is primarily topographical, particularly the rendition of the background, but Earle did not shy away from injecting some social observation into this work. There is no sense at all, for example, that Maori have any dominion over the land. They are sitting passively while the ships - the symbols of European commerce and possibly military might are in command of the harbour. Earle is asking the viewer to look at the scene from the perspective of the Maori seated above the bay, and in doing so, emphasises how Maori have been reduced almost to onlookers rather than participants in the new economy and society that is busy expanding into this region. ${ }^{62}$ 
Explanation of a view of the Bay of Islands, New Zealand, exhibiting in the Panorama, Leicester Square [picture] painted by the proprietor, Robert Burford, from drawings taken by Augustus Earle, Printed by G. Nichols, London, 63 is an engraving of the same location - though containing much more detail - which was published around a decade later. ${ }^{64}$

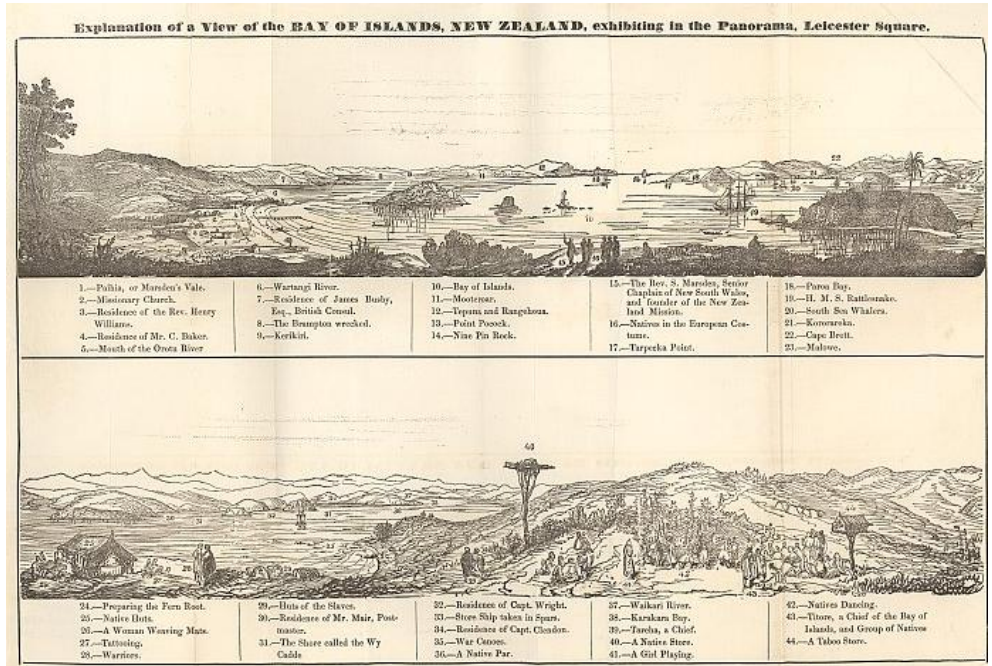

Augustus Earle, Explanation of a view of the Bay of Islands, New Zealand, exhibiting in the Panorama, Leicester Square [picture] painted by the proprietor, Robert Burford, from drawings taken by Augustus Earle, Printed by G. Nichols, London

This engraving may have been based on an enormous panorama that was exhibited at The Panorama - a purposebuilt premises for the display of large works - in Cranbourne Street in London.65 This much is known only because the published version of Earle's engraving of the Bay of Islands mentions that a massive version of it had been exhibited at Burford's Panorama. However, as no records survive of an immense Earle work having been displayed there, 66 all that can be deduced is that either the engraver was mistaken, or that Burford did produce a substantial panorama based on 
Earle's view of the Bay of Islands that was exhibited but subsequently lost.

Regardless of the existence or provenance of any largescale panorama, the engraving that survives is useful if only because it provides great detail about the community in this part of the Bay of Islands, ranging to the location of the houses of various missionaries and other prominent Europeans, to the names and positions of several rivers, hills and other natural features; and importantly, the sites where several prominent Maori resided. It is conceivable that Earle used this panorama - in whatever form he originally created it - as a means of prompting his memory so that when he had more time and resources at his disposal, he would be able to create a variety of paintings based on the scenes referred to in this work. Thus, for example, he includes scenes of 'a girl playing, 'natives dancing', a 'chief of the Bay of Islands', 'natives in the European costumes', 'tattooing', and so forth. All these topics had little artistic merit in the panorama, but would have been useful to an artist as an aide-mémoire for future works. 67

At least one of these quickly-sketched scenes was later converted into a painting by Earle. Maori being tattooed by another Maori in front of a whare 68 contains what the artist obviously had come to see as the obligatory features of a typical Maori village: bags of food elevated from the ground by poles; Maori squatting or lying on the ground; a thatched hut with a thatched lean-to against it; and a view of the sea and an island in the background. ${ }^{69}$ Earle indicated in his Narrative how deeply impressed he was with the manner of Maori tattooing, and how he came to paint this particular scene:

The art of tattooing has been brought to such perfection here, that whenever we have seen a New Zealander whose skin is thus ornamented, we have admired him. It is looked upon as answering the same purposes as clothes. When a chief throws off his mats, he seems as proud of displaying the beautiful ornaments figured on his skin, as a first rate exquisite is in exhibiting himself in his last fashionable attire. It is an essential part of warlike preparations....A very ingenious artist, culled Aranghie, arrived to carry on 
this important branch of his art, which was soon placed in requisition, for all the mighty men in the neighbourhood were one by one under his operating hands.

As this "professor" was a near neighbour of mine, I frequently paid him a visit in his "studio," and he returned the compliment whenever he had time to spare. He was considered by his countrymen a perfect master in the art of tattooing, and men of the highest rank and importance were in the habit of travelling long journeys in order to put their skins under his skilful hands. Indeed, so highly were his works esteemed, that I have seen many of his drawings exhibited even after death. A neighbour of mine very lately killed a chief who had been tattoo'd by Aranghie, and, appreciating the artist's work so highly, he skinned the chieftain's thighs, and covered his cartouch box with it.

I was astonished to see with what boldness and precision Aranghie drew his designs upon the skin, and what beautiful ornaments he produced; no rule and compasses could be more exact than the lines and circles he formed. So unrivalled is he in his profession, that a highly-finished face of a chief from the hands of this artist, is as greatly prized in New Zealand as a head from the hands of Sir Thomas Lawrence is amongst us. It was most gratifying to behold the respect these savages pay to the fine arts. This "professor" was merely a kooky or slave, but by skill and industry he raised himself to an equality with the greatest men of his country; and as every chief who employed him always made him some handsome present, he soon became a man of wealth, and was constantly surrounded by such important personages as Pungho Pungho, Ruky Ruky, Kivy Kivy, Aranghy Tooker, \&c. \&c. My friend Shulitea (Te Whareumu) sent him every day the choicest things from his own table. Though thus basking in the full sunshine of court favour, Aranghie, like a true genius, was not puffed up with pride by his success, for he condescended to come and take tea with me almost every evening. He was delighted with my drawings, particularly with a portrait I made of him. He copied so well, and seemed to enter with such interest into the few lessons of painting I gave him, that if I were returning from here direct to England, I would certainly 
bring him with me, as I look upon him as a great natural genius. 70

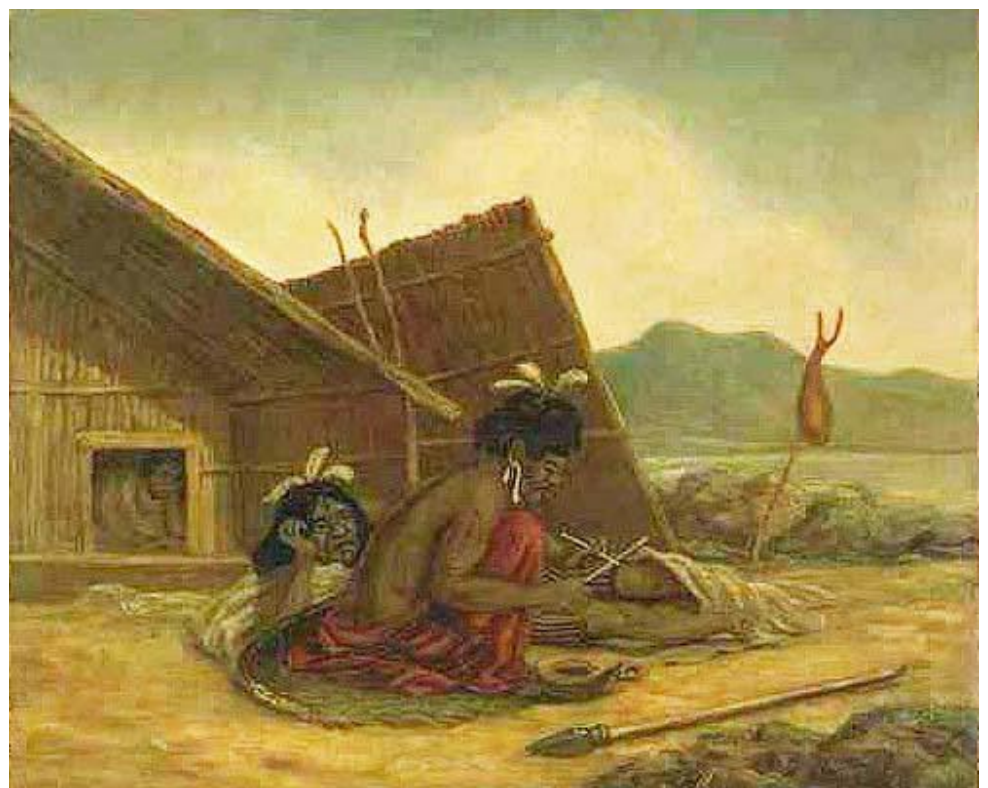

Augustus Earle, Maori being tattooed by another Maori in front of a whare

In Maori being tattooed, however, there is a specific action that is the focal point of the painting, of the sort that is either absent or less apparent in some of Earle's other works from New Zealand where static scenes sometime dominate. The chief being tattooed is lying down, propping up his head with his arm while leaning on his elbow. However, although he is a chief, and although he is the one having his skin decorated, Earle chose to highlight the role of the tattooist in this work. The man carrying out the procedure has a red blanket wrapped around his lower body, which could be an allusion to the great quantities of blood that were often shed during tattooing, but was also the familiar means by which Earle highlighted characters in his paintings. Curiously, there is nothing in this picture of the detail of the tattoo. Earle seems to have concerned himself more with act of making the tattoos, 
rather than with the designs themselves. This can possibly be accounted for by the fact that the patterns of Maori tattoos were already well known in England by this time as a result of the widespread publication of engravings from as early as Cooks voyages, ${ }^{71}$ and the growing trade in dried Maori tattooed heads. ${ }^{72}$

This work can also be seen as a case of Earle giving recognition to a fellow artist, hence the reason for the tattooist being highlighted by red clothing. The medium and artistic tradition may have literally been worlds apart, but Earle recognised artistic talent regardless of its cultural setting.

Another painting that might have been completed after Earle's visit to New Zealand, based on sketches he produced while in the country, is Entrance of the Bay of Islands, New Zealand. 73 The composition of the elements is not too dissimilar to his View near Rio de Janeiro. ${ }^{74}$

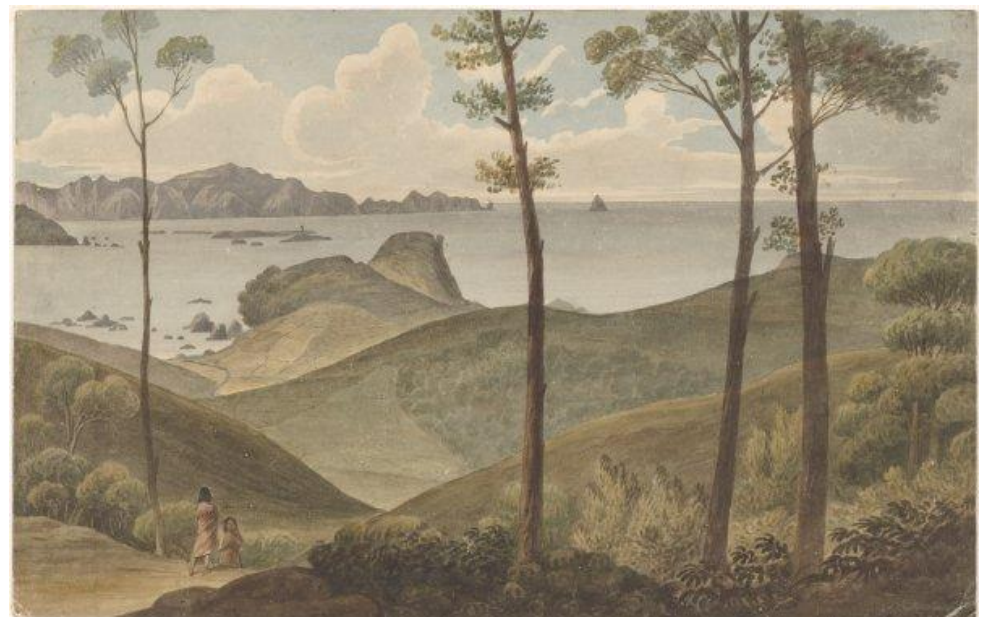

Augustus Earle, Entrance of the Bay of Islands, New Zealand.

Both have very similar-shaped trees in the foreground, water and hills in the background (even some of the undulations of the hills look suspiciously alike), and people on one side walking along a basic path. The market for paintings of scenery such as this would have been almost non-existent 
in New Zealand, ${ }^{75}$ and so it would be safe to assume that this work was intended for buyers elsewhere - possibly Australia, but more likely, England. This being the case, Earle could afford to forego topographical accuracy for the sake of creating a painting which would be more aesthetically appealing to audiences - and purchasers - back in England.

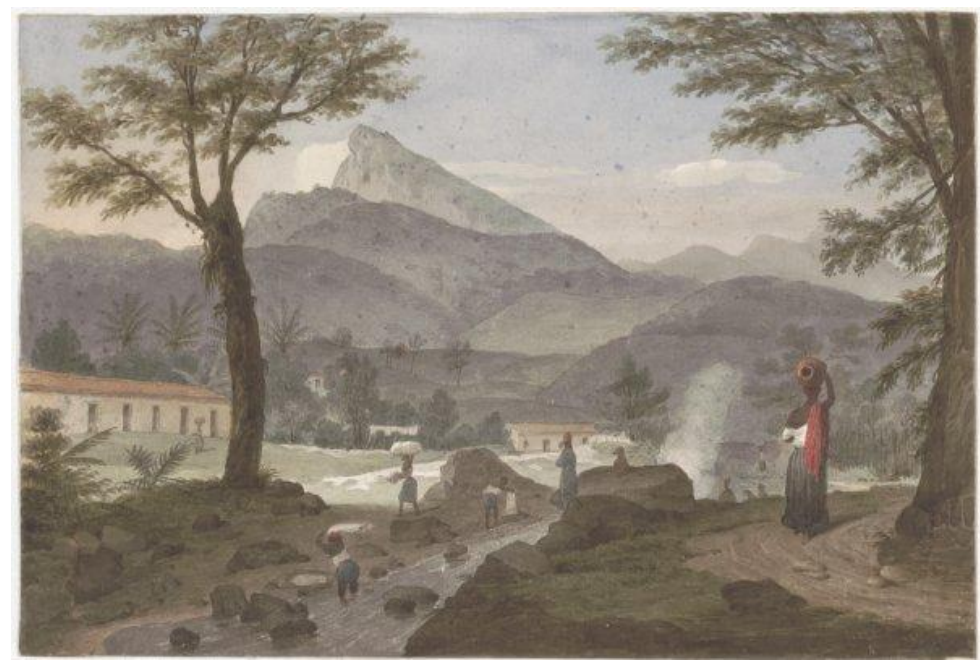

Augustus Earle, View near Rio de Janeiro

\section{Shunghie}

A few days after he had paid his unrewarding visit to the Anglican mission at Paihia, Earle was busy working with a large group of Maori, building huts in Kororareka - probably in order to earn some extra income or in exchange for food and accommodation. Suddenly, there was a great panic among the Maori on this building site. They all rushed off in different directions, and returned minutes later with their muskets, as if they were preparing themselves for a battle. Earle was puzzled by the frantic nature of this transformation of workers into soldiers. He asked around until someone told him that the reason for this flurry was that someone had spied the notorious chief Hongi Hika (referred to by Earle as 'Shunghie') 
crossing the bay with a party of his troops. Hongi was regarded as a friendly chief to the people at Kororareka, but such was his reputation - Earle labelled him as a man of 'desperate ambition, and consummate cunning' - that the Maori in the vicinity immediately armed themselves, partly as a possible precaution, and partly as a feigned compliment to show the extent to which they honoured the military prowess of this approaching guest. 76

For Earle, curiosity rather than apprehension dominated his thoughts: 'This man, Shunghie', he confessed in his Narrative, 'was a most extraordinary character, and a person I had long had a great curiosity to see, his daring and savage deeds having often been the subject of conversation in New South Wales. In his own country he was looked upon as invulnerable and invincible....His friends called him "a god," and his enemies feared him as "a devil." The reason for this admiration and awe was the unparalleled reputation Hongi had as a warlord throughout the entirety of the North Island. Earle related a popular example to illustrate his point: 'Last year, Shunghie made war upon, and totally annihilated, the tribe who had fifteen years previously attacked and murdered the crew of the "Boyd." He had long determined to take revenge for that treacherous action, as he always styled himself "the friend of the English." After this, he removed his residence, and took possession of the conquered district'. 77

Earle's excitement is almost palpable, and it is not difficult to detect in these extracts (and through knowing Earle's predilection for exotic or engaging subjects) a desire by the artist to paint the feared chief. Hongi arrived soon afterwards, landing just over a kilometre from the main settlement in Kororarka. Knowing that this was such an important figure in the country, Earle rushed to get an interpreter and then immediately went to the chief to pay his respects and greet him.

When he arrived at his encampment, Hongi was with his slaves, preparing a meal for breakfast. Earle jotted down his observations as he looked on: The scene altogether was highly interesting. In a beautiful bay, surrounded by high rocks and overhanging trees; the chiefs sat in mute contemplation, their arms piled up in regular order on the beach. Shunghie, not 
only from his high rank, (but in consequence of his wound being taboo'd, or rendered holy,) sat apart from the rest. Their richly ornamented war canoes were drawn up on the strand; some of the slaves were unlading stores, others were kindling fires. To me it almost seemed to realize some of the passages of Homer, where he describes the wanderer Ulysses and his gallant band of warriors'. ${ }^{78}$

Earle, Shand, and possibly Duke, along with a handful of the more plucky Maori in their company, then approached this legendry warrior and introduced themselves to him. 'He received us kindly', Earle commented, 'and with a dignified composure, as one accustomed to receive homage. His look was emaciated; but so mild was the expression of his features, that he would have been the last man I should have imagined accustomed to scenes of bloodshed and cruelty. But I soon remarked, that when he became animated in conversation, his eyes sparkled with fire, and their expression changed, demonstrating that it only required his passions to be roused, to exhibit him under a very different aspect'. ${ }^{79}$

At this point, Earle moved from social commentator back to artist, and his observations went to the image that Hongi cast: 'He was arrayed in a new blanket, which completely enveloped his figure, leaving exposed his highly tattooed [sic] face, and head profusely covered with long black curling hair, adorned with a quantity of white feathers. He was altogether a very fine study; and, with his permission, I made a sketch of him; and also one including the whole group'. 80 The painting Earle made of this scene was almost certainly done in Australia later that year, based on these sketches. 81

The mention of a sketch in Earle's Narrative is informative in the context of events that took place during this stage of Earle's stay in New Zealand. It is likely that Earle lost many of his works when the hut in Kororareka that he was staying in caught fire. He never made any reference in his Narrative to losing any of his sketches or paintings in the fire, but this might have been because it would reveal the extent to which many of his New Zealand scenes were painted later on, either in Australia or England (based on rough sketches and memory), and not on location as might initially appear to viewers. This was a misapprehension that Earle was reluctant 
to correct, possibly because of the impact it might have among viewers on their perception of the 'authenticity' of the scenes in these works. An image of the wilds of New Zealand, created in the comfort of a Sydney studio, was hardly bound to possess the same feeling of excitement for audiences as one that had been painted in situ.

Within a week of Earle returning to Sydney, however, news leaked of the fire and its impact on the artist, and quickly found its way into a Sydney newspaper: 'Had it not been for the very considerable and handsome conduct of Mr. Laidley, Mr. Earle would have been unable to accomplish the chief end of his visits to New Zealand. The hut built for this gentleman and Mr. Shand, by the natives, by accident took fire and was burnt down, and with it most of Mr. Earle's drawings were consumed. He did not write for more paper, or if he did his letter miscarried, and his friends expecting his immediate return, sent him none. Mr. Laidley is a stranger to Mr. Earle, but learning his hard fate, he most handsomely forwarded him paper, without which Mr. Earle would have returned to the Colony almost empty handed'.82 Fortunately for Earle, though, there was no means by which anyone could distinguish which of his paintings were created in New Zealand, and which were produced elsewhere afterwards, so the issue of the 'authenticity' of his New Zealand works did not become the problem that it potentially could have been.

Augustus Earle, Meeting of the artist and Hongi at the Bay of Islands, November 182783 is the title Earle gave to his depiction of his encounter with the chief, and became one of the seminal paintings in his entire corpus of works. Its title with the correct spelling of Hongi (not Shunghie as it appeared in the Narrative) - is further evidence that it was painted months or even years after the event. Using the medium of oils (rather than the faster and more common option for Earle of watercolours), Earle fashioned a slightly contrived image of a supposedly chance encounter between the most prominent (and notorious) chief in the country, and a visiting English artist. This was an historic moment as far as Earle was concerned, and he drew on his early training in the rendering of historical subjects to make this an especially heroic picture. ${ }^{84} \mathrm{He}$ went as far as referring to Hongi and his 
entourage as realising some of the same traits as Homer's 'Ulysses and his gallant band of warriors', 85 thus making the classical allusion in the painting much more explicit. The art historian Michael Dunn has noted that Earle 'composed his picture rather like the academic works, closing the foreground off with Maori figures silhouetted against the middle distance where the main action takes place', 86 in the manner of so many late eighteenth and early nineteenth century paintings of classical scenes.

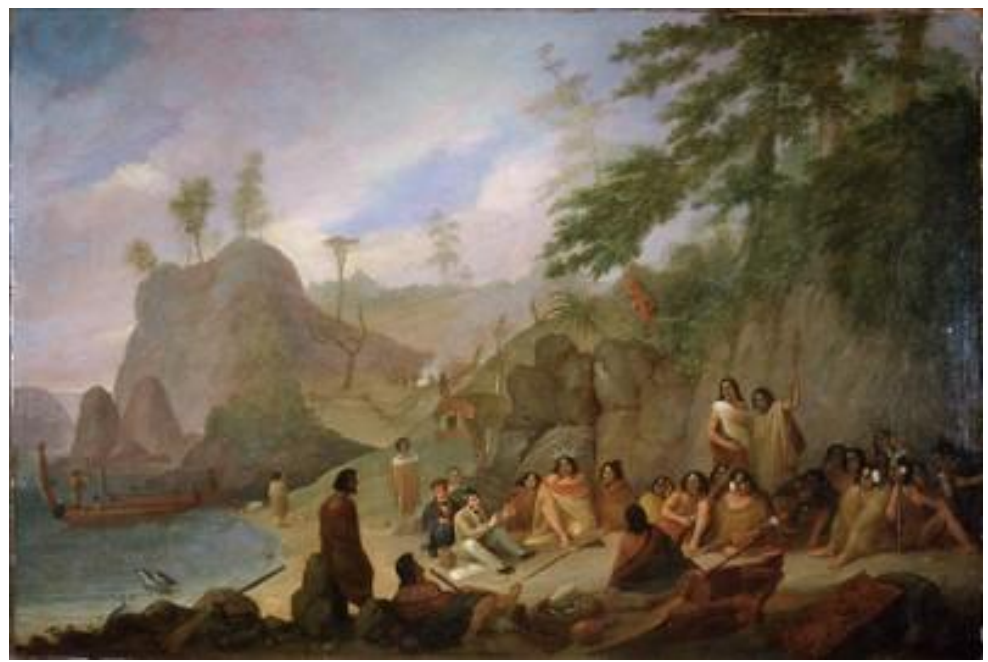

Augustus Earle, Augustus Earle, Meeting of the artist and Hongi at the Bay of Islands, November 1827

Dunn explores further the relationship between Maori and European in this work, suggesting that This is a painting where the Maori are in ownership of the land, their canoes lie in the bay and their carved pataka (storehouse) fits naturally into the landscape. It is Earle and his companions who are the intruders and whose situation is fragile'. 87 This is indeed the case. There are sufficient clues, including the disproportion between the number of Europeans and Maori in the scene, the seating arrangements, and the sense of Europeans being enclosed by the natural features of the setting, to show where the power rests. 
However, power is one thing, and celebrity is another. Despite the colossal reputation that Hongi carried with him by this stage in his career - very superior to any other native I have yet seen.... esteem him the greatest man that has ever lived in these islands. His name carries terror with it throughout the whole of New Zealand', 88 as the missionary Richard Davis wrote - Earle opted to make himself, and not this feared chief, the main subject of his work. Hongi is barely discernable from those Maori sitting next to him. Earle had many options for raising the prominence of the chief in this picture, but apart from placing him roughly in the centre, Hongi does not stand out as the main figure. This honour goes - not entirely surprisingly - to Earle. Augustus Earle, Meeting of the artist and Hongi at the Bay of Islands is another of Earle's self-portraits, although in this case, he is far less understated in his treatment of himself than usual. He is sitting at a slight angle to the viewer, but in a way that allows him to capture the sunlight more than any other character in the picture. He is also gesturing with his hands, as thought he is explaining something to Hongi, while the chief listens passively. It is presumably Shand who is sitting immediately behind Earle, and so is partly obscured by the artist.

By affording himself such prominence, Earle is betraying a specific urge he had - one which he partially satiated through his incessant travelling and his frequent self-portraiture in the various locations he visited - to be part of the history of the places he explored, rather just than to record images of them. In Augustus Earle, Meeting of the artist and Hongi at the Bay of Islands, the Homeric dimensions to which he refers suddenly seems audacious when the viewer considers that the artist deigned himself worthy to be not only part of but central to such an heroic scene. As Gil Docking summarised it, 'the painting is not only a beautifully romanticised record of the meeting but is likewise a visual summary of Earle's character and philosophy of life - of his somewhat egotistical nature, of his literary and classical inclinations and powers of observation, of his egalitarianism and disposition to be mentally stimulated by acts of ferocity contrasted with peaceful scenes'. 89 
The careful arrangements of the elements in this painting obviously appealed to Earle, because he produced another work - The wounded chief Honghi \& his family 90 - which bears a very close compositional resemblance to Augustus Earle, Meeting of the artist and Hongi at the Bay of Islands. In The wounded chief Honghi $\&$ his family (which was also produced either in Australia or even later, in England), Earle had a similar beachfront setting, with an almost identical background (right down to the positions of the canoes and smoke from a fire on the hill), very similar cliffs near the sand, and most strikingly, Earle and (presumably) Shand seated in an almost matching position, with Earle using the same hand gestures as he speaks to the dying chief.

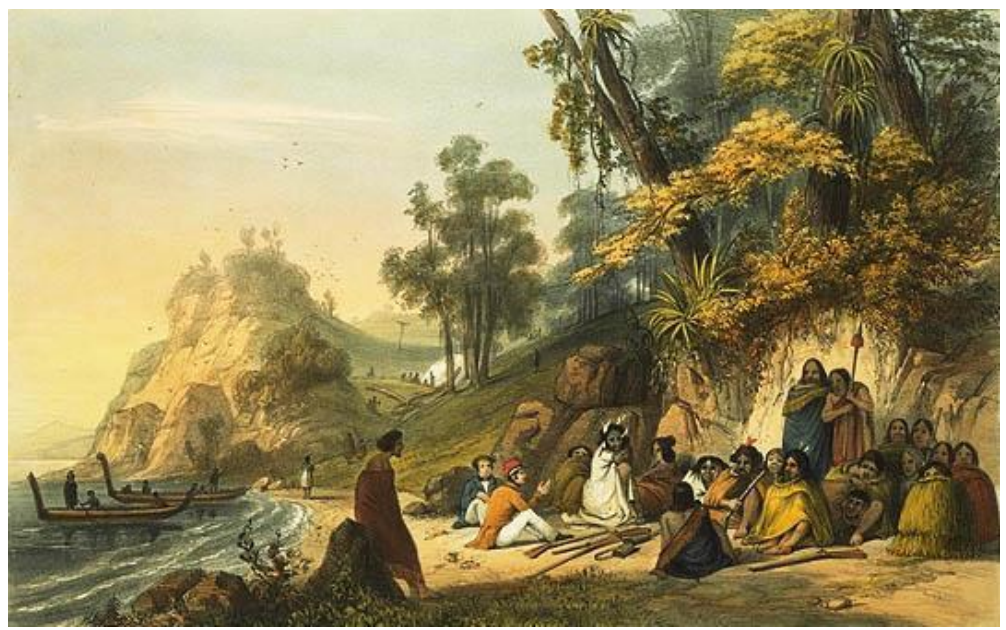

Augustus Earle, The wounded chief Honghi \& his family

It is known that Earle visited Hongi only once, ${ }^{91}$ and so it seems that when Earle later decided to paint a second image of his meeting with the chief - probably for commercial reasons ${ }^{92}$ - he chose simply to produce a very close variation of Augustus Earle, Meeting of the artist and Hongi at the Bay of Islands under another title rather than create an entirely new perspective of the scene. 
The importance of Hongi's impending death can be gauged from the observations Earle noted in his journal about this episode. As he described how the chief was 'fast sinking into the grave', he also revealed the effect this was having throughout the region:

we were once more thrown into alarm by a threatened invasion. A rumour was circulated in the village [Kororareka, where Earle was staying], that Shunghie, who now lay at the point of death, had declared that he would make one last glorious effort before he expired. He was resolved (it was reported) to collect his warriors, overcome George and his followers, possess himself of Ko-ro-ra-di-ka, and die upon the conquered territory of his enemy; and I had no doubt that in his moments of delirium such had been his exclamations, as it had always been one of his favourite projects. When this was reported to George, he immediately came to us, and with a most doleful countenance told us we must take care of ourselves; for, if the report proved true, he was much too weak to protect us. This certainly caused us some alarm, but, fortunately for us, a good sized whaler, "the Marianne," was then lying at anchor in the port, having arrived but a few days previously. The presence of a ship, all over the world, is felt as a protection to Europeans, as in case of danger it is a sure place of refuge. ${ }^{93}$

As Hongi's biographer, Dorothy Urlich Cloher, noted, 'a dying Hongi still had the capacity to elicit strong reactions', and that despite is weakening physical state, his enemies were still nervous at the possibility that he might attack them something that they were not confident of withstanding.94 Indeed, such was Hongi's reputation that chiefs who met him would almost habitually fawn in his wake. Earle could not help but find this reaction from otherwise proud tribal leaders as curious, and a reflection on how the balance of power among many Maori communities had the potential to tip to such a dramatic degree:

I was much amused with the punctilios used in the visit of ceremony paid to Te Whareumu. Shunghie, 
accompanied by about a dozen of his chiefs, advanced towards our settlement, leaving their guns and hatchets behind them: as they approached, all our tribe discharged their pieces in the air. When they met, all rubbed noses (a ceremony never to be dispensed with on formal occasions).

They were then conducted by Te Whareumu to his huts on the beach; and in the enclosure in front of them the warriors squatted on the ground. Shunghie, being tabooed, or under the immediate protection of their Atua or God, still sat apart. Then the mother of George, called Tururo, or the Queen, and who is regarded quite as a sybil by the whole tribe, approached Shunghie with the greatest respect and caution, and seated herself some paces from his feet. She then began, with a most melancholy cadence (her eyes streaming with tears and fixed upon the ground), the song of welcome. All their meetings of ceremony or friendship begin with the shedding of copious floods of tears; and as Shunghie's visit was such an unhoped for and unexpected honour, so much greater in proportion was the necessity for their lamentations. This woeful song lasted half an hour, and all the assembly were soon in tears; and though at first I was inclined to turn it into ridicule, I was soon in the same state myself. The pathetic strain, and the scene altogether, was most impressive. As the song proceeded, I was informed of the nature of the subject, which was a theme highly calculated to affect all present. She began by complimenting the wounded warrior, deploring the incurable state of his wound, and regretting that God was wanting him, and was about so soon to take him from his friends! Then she recounted some of his most celebrated deeds of valour; naming and deploring the number of his friends who had fallen bravely in the wars, and lamenting that the enemies who had killed them were still living! This part seemed to affect them powerfully; and when Tururo ceased her song (being quite exhausted) they all rose, thus demonstrating their respect and approbation. ${ }^{95}$

Of course, Earle was astute enough to distinguish between an outward show of respect, and the concealed fear that prompted such displays. Yet, the deference being paid to Hongi, even though he was close to death, intrigued him, as 
did the strength of the chief's reputation, and the fear it was still capable of instilling in people in the region.

The following morning, Earle was woken by the most dismal sounds I had ever heard'. He got up to see what the cause of the commotion was, and saw Hongi's party preparing to leave. Such was the feigned regret at this parting that some of the Maori present 'were crying most piteously, and cutting their flesh as a cook would score pork for roasting....All were streaming with tears and blood, while Shunghie and his friends embarked in their large and richly ornamented canoes, and sailed from our beach'. It was only when Hongi and his followers had gone that Earle discovered the deeper feelings of the host community: 'notwithstanding their apparent affection, Te Whareumu and his friends were most happy their visiters [sic] had left them; and that it was more the dread of Shunghie's power, than love for him, that induced them to treat him with such respect and homage'. ${ }^{96}$

Indeed, the relief at the news of Hongi's departure was so great that there were celebrations immediately afterwards. Slaves brought copious supplies of fish, potatoes and kumara, and after this feast, there was dancing that went on well into the evening. A coloured lithograph based on an Earle drawing of the slaves organising the meal was published in London in 1838. Slaves Preparing Food ${ }^{97}$ contains what had become the standard elements in Earle's portrayal of Maori settlements: cloaked Maori huddling in small groups on the ground; a fire smoking away; water, boats, and hills in the background; food stored in bags on poles; and small huts behind the people who are pictured in the work. While the scene has realistic elements in it, their arrangement - particularly their spacing suggests that the artist may have exercised some compositional license when it came to organising this image.

The dances of some Maori in this group fascinated Earle, and were to form the basis of at least three works on the subject. In his Narrative, he gave the following account of the performances he witnessed that night: "The dances of all savage nations are beautiful, but those of the New Zealanders partake also of the horrible. The regularity of their movements is truly astonishing; and the song, which always accompanies a dance, is most harmonious. They soon work themselves up 
to a pitch of phrensy; the distortions of their face and body are truly dreadful, and fill the mind with horror. Love and war are the subjects of their songs and dances; but the details of the latter passion are by far the most popular among them. I was astonished to find that their women mixed in the dance indiscriminately with the men, and went through all those horrid gestures with seemingly as much pleasure as the warriors themselves'. 98

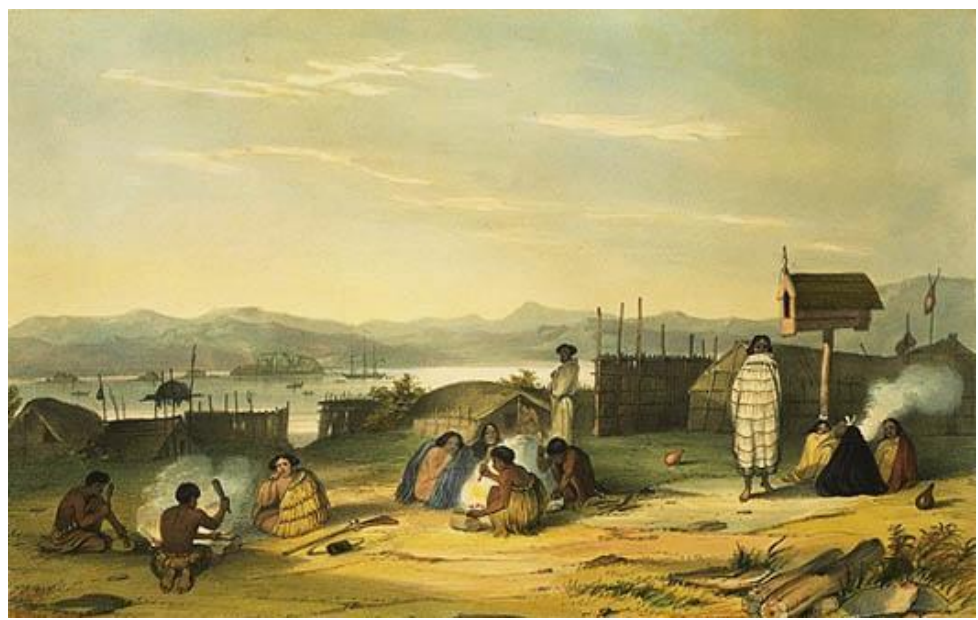

Augustus Earle, Slaves Preparing Food

Two of the paintings that these dances inspired are studies of individuals. New Zealand dancer, no. $1^{99}$ and New Zealand dancer, no. $2^{100}$ show Maori men in animated poses with contorted faces. By themselves, much of the effect of the group dance of which they were a part is lost, but Earle compensated for this by allowing the viewer to focus on the appearance of an individual, rather than the cumulative effect of the group. The first man has tattooed upper legs, and is holding a hani (a small fighting staff). His eyes are wide open and staring to one side, while his mouth is also wide open, as though he is shouting as he performs. The second picture is even more dramatic. The man's face is fully tattooed, his wiry body (for which only a flimsy loincloth affords some modesty) 
is in a theatrical pose, the whites of his eyes are pronounced, and his tongue is poking out and pointing downwards. ${ }^{101}$

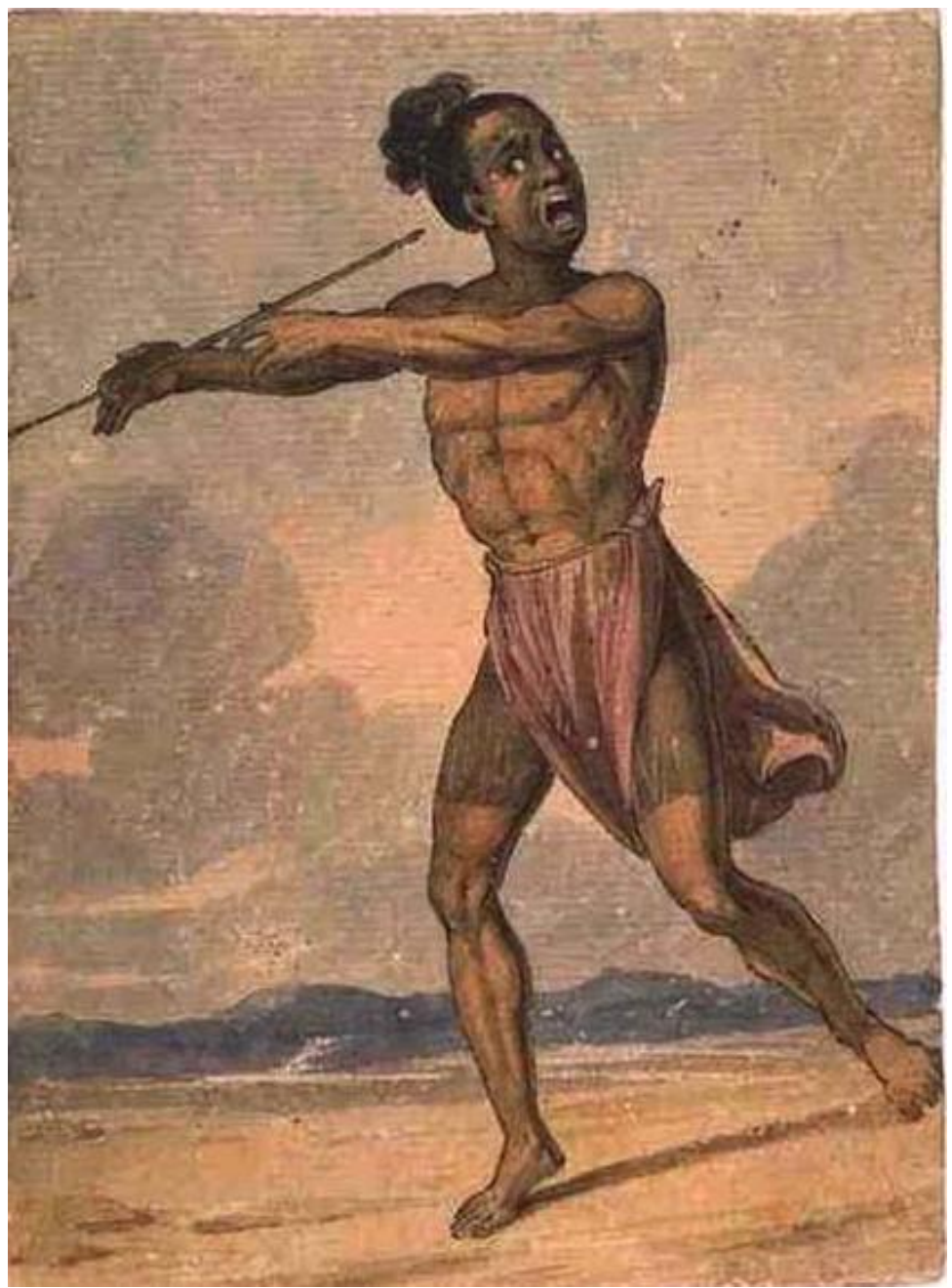

Augustus Earle, Dancer, no. 1 


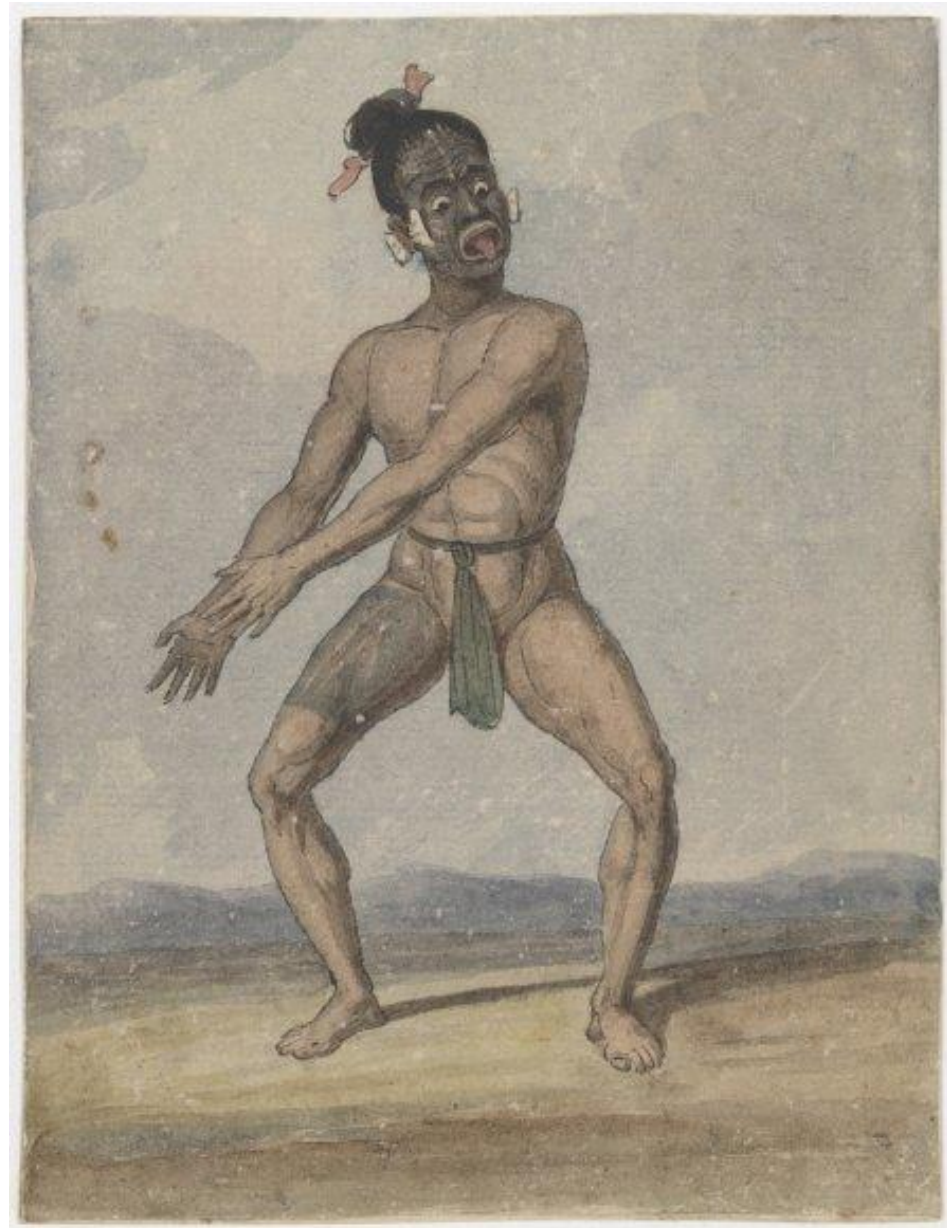

Augustus Earle, Dancer, no. 2

Both of these works could pass for anthropological studies of the period, but the way in which Earle executed them detracts from their overall objectivity. Both men appear as caricatures, and whereas some of Earle's paintings of New Zealand scenes are less dramatic than the written descriptions that can accompany them from his Narrative, in the case of 
these two works, they match the vigour of the dances as Earle portrayed them in his book.

For reasons possibly associated with cost, but also in anticipation of a far more ambitious work which he was planning at the time of his death, Earle's Narrative is sparsely illustrated. However, one of the engravings that did make it into the book is A Dance of New Zealand, ${ }^{102}$ which depicts around ten Maori - men and women - performing a choreographed dance (the movements show this to be the case) in front of a group of around a dozen women, all of whom are seated on the ground, watching intently. The engraving is poorly executed, though. The heads of some of the dancers are not in proportion to their bodies, or to the heads of others in the group, and like New Zealand dancer, no. 1 and New Zealand dancer, no. 2, this work leans towards being a caricature of Maori dancers more than an attempt at an honest and accurate rendition.

Before leaving the Bay of Islands, Earle produced two watercolours of Rangihoua - a location that was unremarkable but significant for a potential client he may have had in mind back in Sydney: Samuel Marsden. This was the spot where Marsden had first landed in New Zealand, and was where, on 24 February 1815, he purchased the plot of land on which New Zealand's first missionary settlement was established. 103

Ranghe Hue, a New Zealand fortified village, the residence of Warri-Pork ${ }^{104}$ portrays a pa on the slopes of a hill. The scene was painted using one of Earle's favoured techniques of contrasting the subject of the work with a distinct foreground. This helps to give a sense of perspective and distance, but was also used by Earle as a platform for another common device he employed - people with their backs to the viewer, looking at the scene. The message is that there is something worthwhile to look at for the people in the painting, and by extension, that the viewer also ought to find the subject interesting. That the two people featured in the foreground are Maori helps to establish the location of the scene (the pa details are too small to enable the viewer to be certain about whether this is a New Zealand setting), and Earle ensured that the man standing in the foreground had a red blanket wrapped around him - one of 
his signature methods of directing the eyes of the viewer to a particular place or person in the painting. Otherwise, though, this is a typical watercolour of the period, sufficient in quality to maybe attract the interest of Marsden or members of his mission, but far from being of a quality that would make it an exhibition piece.

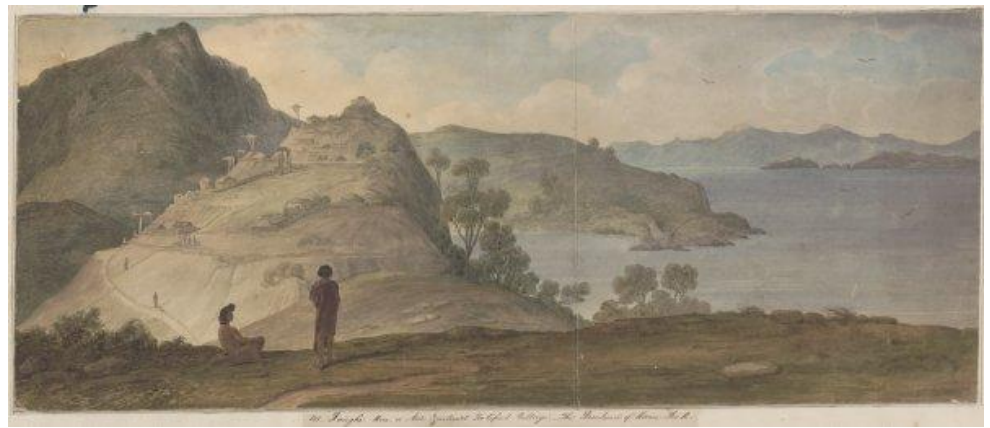

Augustus Earle, Ranghe Hue, a New Zealand fortified village, the residence of Warri-Pork

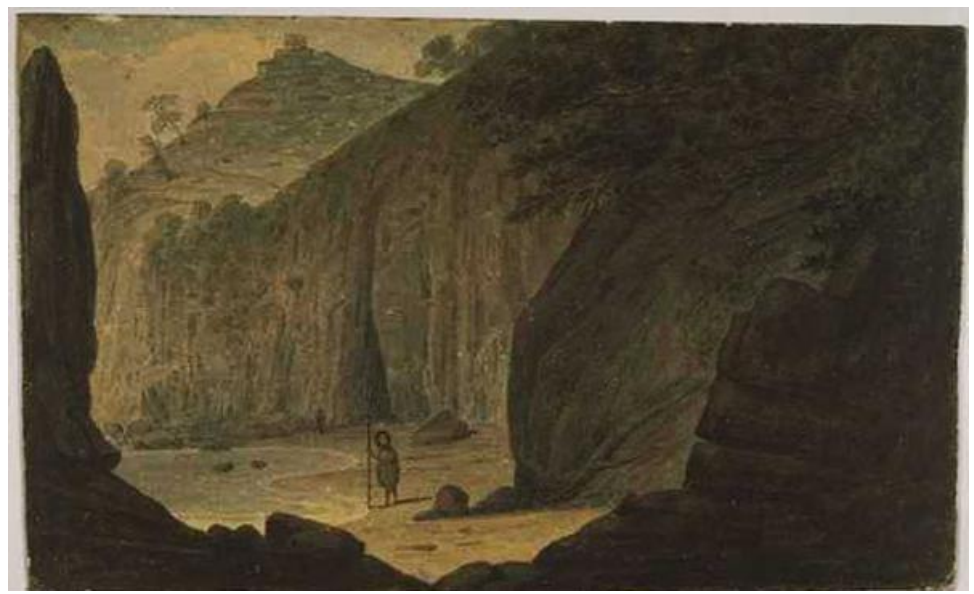

Augustus Earle, Ranghe-hue Bay of Islands, N. Zealand

And while the other painting of Rangihoua - Ranghe-hue Bay of Islands, N. Zealand 105 - also was never exhibited, it is clearly of a superior standard. It represented one of those 
points in Earle's career where he was departing from some of the more rigid classical influences that were evident in certain of his previous works, and towards a style that emphasised the emotional and even the spiritual sense of place. There are strong similarities between Ranghe-hue Bay of Islands and View on the coast of New South Wales, Illawarra ${ }^{106}$ in the organisation of some of the elements in the painting, and the sort of emotional intensity these works convey to the viewer.

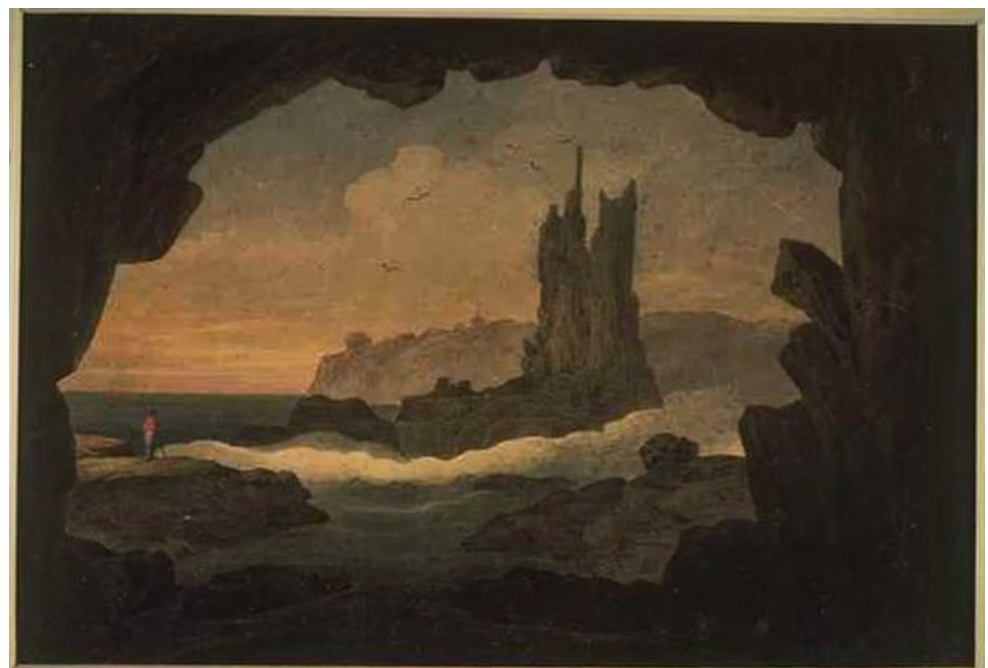

Augustus Earle, View on the coast of New South Wales, Illawarra

Both paintings are framed on either side and in the foreground by very dark, ominous rock formations, and both emphasise how diminutive humans are in the face of nature. As one art historian observed with works of this sort, 'such figures were often used to symbolise men's aspiration to the infinite...or a related feeling of mans smallness in the vast face of nature, a kind of pleasurable vertigo, an awful frisson, theoretically justified by Burke's concept of the Sublime'. ${ }^{107}$

In Ranghe-hue Bay of Islands, the light falls on a small area in the centre of the image, where a Maori man is standing. He is nearly completely encircled by tall, dark cliffs, and seems almost insignificant when standing in this location 
- almost. The placement of this man on a small patch of seashore, surrounded by these towering cliffs was not merely a device to show (or exaggerate) the scale of the natural features at Rangihoua. Earle was striving to express a state of mind a feeling that was too intense and too elusive to be defined clearly by simply producing a work of clinical topographical accuracy. There is something of Ernst Hoffmann's 'infinite longing'108 in Ranghe-hue Bay of Islands, both for its clear affinity with the wild and mysterious aspects of nature, and for the cloaking of the entire work in a sense of deep melancholy. The connection between this location and the commencement of missionary work in New Zealand may well have been Earle's motivation for casting this scene in such an awe-inspiring way, but whatever the reason, Ranghe-hue Bay of Islands is one of the more contemplative studies Earle produced, certainly while in New Zealand.

\section{'Excursions into the Interior'}

On 24 November, having been in the Bay of Islands for around three weeks, Earle made plans to return to Hokianga, where he was due to catch a ship back to Australia. While in Kororareka, he had made good friends with several local Maori, and they were evidently reluctant for him to leave - so much so that he was only able to effect his departure by promising them that he intended to return in the near future. ${ }^{109}$

Packing and organising took longer than expected, and Earle and his party did not manage to get to the Kerikeri river until nightfall, which frustrated him greatly. It was dark, the tide was ebbing against them, and so any plans of advancing up the river were abandoned. The group therefore decided to seek shelter for the night, and to make a fresh attempt the following day when the conditions would be more favourable. There were no huts in the vicinity, and no obvious place that afforded this small band of travellers adequate shelter. As they discussed how to make best out of these circumstances, one of them saw a light near the shore, and they all agreed to head in that direction. However, the tide was out, and their boat got stuck in the muddy foreshore well before they were able to reach the area where the light had been seen. All Earle 
and his colleagues could do was to wade through the kneedeep mud to escape their predicament. As they struggled through this morass, they came across a group of women, sitting around a fire in the midst of the swamp. They were there to collect shellfish, and had decided to remain on location overnight. 110

Earle and his fellow travellers had no option but to join these women. However, the experience was an uncomfortable one, as he later related: "The moment we were seated, the water began to ooze out an inch or two all round us. We sought in vain for a dry place, for we were enveloped in darkness, and surrounded by rushes and flags six or seven feet high; but being very much fatigued, we slept, notwithstanding the misery of a wet bed, with a cloud of fog for curtains. I did not wake till one of the women gave me a good shake, and informed me that the day was well up'. These sturdy women provided a substantial breakfast for their guests, and even carried them to the their boat. As far as Earle was concerned, this display of generosity 'was another proof to me that the English are quite safe, though travelling unguarded, amongst these people'. ${ }^{111}$

The next morning was Sunday, and although some local missionaries nearby pleaded with Earle's group not to undertake their journey along the river on the Sabbath, the deadline to meet the ship in Hokianga meant that there was no time to spare. When Earle and Shand finally reached the west coast of the North Island, they discovered that the brig they had planned to board for Australia was now due to depart for Tongatapu instead. The two colleagues determined that rather than board the ship and undertake this diversion, they would remain in New Zealand - a decision that had several chiefs pleading with them to join their communities (in the hope that the presence of Europeans in their villages would bring about a sudden growth in trade). However, Earle was eager to return to the Bay of Islands, even though ignoring completely the pleas of the Hokianga Maori to stay in their community would be difficult. Earle described how he was 'at a loss how to evade the kind importunities of our savage hosts without giving them offence. "Is not our country as good as theirs?" - "Are you not as safe amongst us?" -"Are we not as 
willing and as capable of protecting you as Shulitea?" These were the arguments they used; and, finally, we were obliged to inform them that we had a friend and countryman (Captain Duke) settled on the other side, who was preparing a house for our reception. On being informed of this circumstance they consented to part with us, though evidently with great reluctance'. 112

While in Hokianga, Earle was witness to another Maori cultural practice that intrigued him enough that he decided to make a painting of it. The occasion was the death of the senior Hokianga elder, Rewha (spelt 'A Rowa' by Earle), who was the father of Moetara, the Ngati Korokoro leader whose reputation as a great chief by this time was well-established.113 Earle provided details in his Narrative of the events related to these rites of death:

These deaths, when they occur among men of rank, are generally accompanied by some horrible scenes of butchery amongst their slaves,- a common custom among all savages, but practised here, (I was informed,) with peculiar cruelty. We went on shore to witness the ceremony of A Rowa's lying in state, hoping at the same time that our presence might induce them to dispense with some of those barbarous cruelties which generally accompany their funeral rites. We had, indeed, every reason to think we had conjectured rightly, for nothing of the kind took place; which was considered by all as a circumstance somewhat remarkable. A great concourse of savages had assembled all round the village of the deceased chief) and there was a tremendous firing of muskets, but no particular marks of grief. I spoke to Mooetara, and requested, as a favour, if it were not breaking through their established rules, that he would conduct me to the body of his father. He accordingly led me to the outside of the village; and under a rude hut (constructed for the purpose) lay the body of the deceased chief, closely covered up with mats, leaving only part of the face and head exposed; in his hair was stuck a profusion of long white feathers, by way of ornament. Two women (whom I understood were his wives) sat close to the corpse; they were painted all over with red ochre, and seemed to perform the parts of chief mourners. These kept up a low moaning noise, and 
occasionally whisked off the flies from the face of the deceased. ${ }^{114}$

The watercolour he produced, based on this funeral, was Crying over the bones of a dead chief, New Zealand. ${ }^{115}$

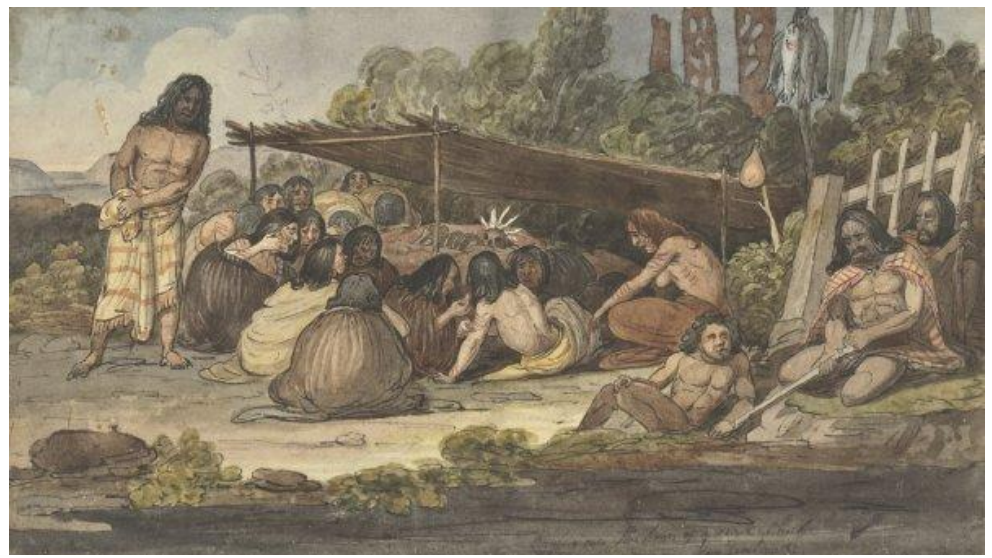

Augustus Earle, Crying over the bones of a dead chief, New Zealand

As with a number of his New Zealand works, this painting was probably produced long after the event that Earle witnessed, and was based more on his memory of the lament than the description of it he had written at the time. However, he did manage to convey the fact that there were no particular outpourings of grief, of the sort that traditionally so obvious at such events. The rites - such as they are evident in this painting - appear almost banal, and the main sentiment that is evident on the faces of those Maori present is not of grief or loss, but of curiosity. To the left of the picture, a man stands, arching over the seated woman, hoping to catch a glimpse of the remains of the dead chief, while in the foreground on the right, three Maori are slouched casually, as though passing the time of day away in idle conversation, and showing no interest whatsoever in the fact that just a few metres away, their deceased leader is lying in state. 
Earle attributes this unresponsive attitude by some of those Maori in attendance in part to his presence at the ceremony, but in all likelihood, the indifference he found, and that he captured in Crying over the bones of a dead chief, was more a result of temporal concerns dominating the thoughts of some of those Maori present, as Earle conceded later on: 'I imagine that one reason of no outrage having been committed during this solemn occasion, was our brig being on the point of sailing, and previous to her departure a great deal of traffic was expected to be carried on with the natives, for there was still a considerable quantity of muskets undisposed of; and I think, in this instance, avarice overcame filial affection,- the minds of the chief's family being so intent upon obtaining good bargains, that they had not time to sit and mourn over their departed parent, nor to work themselves up into a paroxysm of passion sufficiently violent to cause them to murder their slaves'. ${ }^{116}$

Earle was encouraged by this, concluding that the general presence of Europeans in the region could only be beneficial to Maori society: "This afforded me a convincing proof, that as soon as they [Maori] are occupied by commerce, or the useful arts, their barbarous rites will gradually be discontinued, and will speedily cease altogether'. ${ }^{117}$

With no ship leaving for Australia, Earle commented in his Narrative that 'we were again alone with these wild yet interesting people'. ${ }^{118}$ How he really felt about remaining in New Zealand, though, is difficult to determine. A few days later, he estimated he might have to wait in the country for a further six months, although the frequency of ships crossing from Sydney to Hokianga makes this conclusion seem a little melodramatic. At this point in the Narrative, he wrote that 'As we were now about to become inhabitants of New Zealand, it became necessary that we should be well acquainted with the particulars of their [Maori] methods of "doing business," and that we should apply ourselves diligently to the study of the language, which we acquired much more readily than I had anticipated'.119 This exaggeration - based on the pretence that he was stranded in the country for at least a further half a year and was learning the native language - is an example of 
Earle embellishing his Narrative in an effort to make his account that bit more eyebrow-raising for readers.

In both his art and writings, though, Earle was a keen observer of different cultures. In New Zealand, where so few Europeans had spent any length of time studying the indigenous people, Earle's notes on Maori customs consequently assumed greater importance than he may have conceived of at the time. However, what he bothered to make note of with respect to Maori cultural practices were mainly those things that were either at odds with his own, European cultural thinking, or that he thought would interest (and perhaps titillate) audiences back in England.

One such episode he relayed involved a chief's wife, who had been discovered committing adultery. The chief took a stone hatchet, and approached his wife without mentioning any of his suspicions. He hit her on the head, killing her instantly, and then dragged her body to the perimeter of the village, where it was left for the dogs to devour. As soon as Earle was informed of this event, and the fact that it happened nearby to where he was staying, he went from being an observer of Maori culture, to a participant in its aberration. He visited the chief and requested permission to bury the body of the woman who had been killed. His request was granted, and he and a few Maori helped take the corpse to the beach, where they interred it with as much decency as circumstances allowed.

Having withdrawn from further involvement in this matter, Earle retreated to his role as a curious observer. He wrote how This was the second murder I was very nearly a witness to since my arrival; and the indifference with which each had been spoken of, induced me to believe that such barbarities were events of frequent occurrence; yet the manners of all seemed kind and gentle towards each other: but infidelity in a wife is never forgiven here; and, in general, if the lover can be taken, he also is sacrificed along with the adulteress. Truth obliges me to confess that, notwithstanding these horrors staring them in the face, they will, if opportunity offers, indulge in an intrigue'. ${ }^{120}$ 


\section{Back to the Bay of Islands}

However long Earle intended to remain in New Zealand (and it was not the several months he suggested in his Narrative after having declined to board the ship from Hokianga to Tongatapu), he knew it would be better staying in the Bay of Islands, rather than in the less populated Hokianga. This time, though, there was no rush to get to the eastern side of the island, and Earle decided to see as much of the country as possible as he travelled back to the Bay of Islands. His account of this journey shows how he was more exploratory on this occasion, and how he kept a keen eye trained on the settlements he came across:

As there were two roads across to the Bay of Islands, and I was anxious to see as much of the country as possible, I determined that my second journey should be by the longest route. I set off, accompanied only by a native boy to carry a small portmanteau, and to serve me as a guide. As, on my former journey, we travelled many miles through thick tangled forests, fatiguing beyond description. In the midst of our toilsome progress, night frequently overtook us; then, by means of my fowling-piece, I procured a light; the boy made a fire; and we passed the night in this vast wilderness, far from the habitation of any human being! At daybreak we resumed our journey; and at length (about ten o'clock) we emerged from the wood, and entered upon extensive plains. These were not naked deserts, similar to the ones I had passed through on my former route, but were diversified with bush and brake, with a number of small villages scattered in various directions. At mid-day we arrived at what in New Zealand is considered a town of great size and importance, called Ty-a-my. It is situated on the sides of a beautiful hill, the top surmounted by a par, in the midst of a lonely and extensive plain, covered with plantations of Indian corn, cumera, and potatoes. This is the principal inland settlement, and, in point of quiet beauty and fertility, it equalled any place I had ever seen in the various countries I have visited. Its situation brought forcibly to my remembrance the scenery around Canterbury. 
We found the village totally deserted, all the inhabitants being employed in their various plantations; they shouted to us as we passed, thus bidding us welcome, but did not leave their occupations to receive us. To view the cultivated parts of this country from an eminence, a person might easily imagine himself in a civilised land; for miles around the village of Ty-a-my nothing but beautiful green fields present themselves to the eye. The exact rows in which they plant their Indian corn would do credit to a first-rate English farmer, and the way in which they prepare the soil is admirable. The greatest deficiency which I observed in the country around me was the total absence of fences; and this defect occasions the natives a great deal of trouble, which might very easily be avoided. ${ }^{121}$

Earle continued with his journey back to the Bay of Islands via the new route, and even if it had not been as hardgoing at times as he mentioned, his claim to have walked eighty kilometres in less than a full day is a bit improbable. ${ }^{122}$ The following day, Earle arrived at Waitangi, and although a brig, under Captain Kent, was due to depart for Australia, he decided to remain in the Bay of Islands, in the company of Te Whareumu, with whom he had build a good rapport.

For a few days, Earle enjoyed the hospitality of his hosts, but the serenity of the location and the goodwill the local Maori showed him was interrupted by a servant rushing to his quarters early one morning with the intelligence that a large number of canoes, packed with warriors, was crossing the bay. This was ostensibly a friendly visit, but Earle sensed that something ominous was about to happen - a feeling that he amplified in the final version of his Narrative, when describing this force's approach: 'The landing of these warriors was conducted with a considerable degree of order....All our New Zealand friends - the tribe of Shulitea - were stripped naked, their bodies were oiled, and all were completely armed; their muskets were loaded, their cartouch boxes were fastened round their waists, and their patoo-patoos were fixed to their wrists. Their hair was tied up in a tight knot at the top of their heads, beautifully ornamented with feathers of the albatross. 
As the opposite party landed, ours all crouched on the ground, their eyes fixed on their visiters, [sic] and perfectly silent'. ${ }^{123}$

The situation was tense. When the landing and disembarking was complete, the chief of these men marched towards where Earle and his party were positioned. When they were close, they stopped abruptly, and there followed something of a standoff:

Our party continued still mute, with their firelocks poised ready for use. For the space of a few minutes all was still, each party glaring fiercely on the other; and they certainly formed one of the most beautiful and extraordinary pictures I had ever beheld. The fore ground was formed by a line of naked savages, each resting on one knee, with musket advanced; their gaze fixed on the opposite party; their fine broad muscular backs contrasting with the dark foliage in front, and catching the gleam of the rising sun. The strangers were clothed in the most grotesque manner imaginable; some armed, some naked, some with long beards, others were painted all over with red ochre: every part of each figure was quite still, except the rolling and glaring of their eyes on their opponents. The back ground was formed by the beach, and a number of their beautiful war canoes dancing on the waves; while, in the distance, the mountains on the opposite side of the bay were just tinged with the varied and beautiful colours of the sun, then rising in splendour from behind them. ${ }^{124}$

Despite Earle's stated fears, the situation was obviously not so dangerous that he was prevented from observing the scene as though he had in mind a future painting of it.

The silence of the standoff was broken by the visiting group performing a war dance (haka) - with 'a great deal of violent pantomimic action and grimace'125 - which was met by a similar performance from the opposing group, of which Earle was nominally a part of. With both parties having put on this display of feigned ferocity, they then ran towards each other as though they were old friends (which some of them were), firing their guns in the air, rubbing each other's noses, and treating the whole matter as if it had all been a 'rough joke'. ${ }^{126}$ 
It was an amicable end, but underneath the merriment and feasting that followed, there was a perceptible anticipation that the visiting tribe was determined 'on executing some atrocity or depredations before their return'. The pretext for this assault was some alleged and old offence a small group of settlers had apparently committed against the visiting group. The response of these warriors was to go to the local blacksmith, break into his premises, and steal everything they could. They then repeated this at the house of another European (who was away at the time), and concluded by saying that they would return soon to attack the local Maori community with which they had recently concluded the friendly meal.

Te Whareumu knew that his people were outnumbered, and consequently, gathered all the members of his community and departed with them, leaving Earle and his fellow Europeans to face any assault. There was no option for the remaining settlers but to marshal their arms in order to defend their property. Within a few hours, all weapons were loaded, defences had been erected, and there was a final scurry of preparations being made for the feared attack. Just at that moment, however, an even greater calamity hit the settlement, which Earle described in some detail:

By some accident one of our houses was in flames. Our situation was now perilous in the extreme. The buildings, the work of English carpenters, were constructed of dry rushes and well-seasoned wood; and this was one of a very respectable size, and we had hoped, in a very few days, would be finished fit for our removing into.

For some seconds we stood in mute amazement, not knowing to which point to direct our energies. As the cry of "fire" was raised, groups of natives came rushing from all directions upon our devoted settlement, stripping off their clothes, and yelling in the most discordant pitch of voice. I entered the house, and brought out one of my trunks; but on attempting to return a second time, I found it filled with naked savages, tearing every thing to pieces, and carrying away whatever they could lay their hands upon. The fierce raging of the flames, the heat from the fire, the 
yells of the men, and the shrill cries of the women, formed, altogether, a horrible combination: added to all this was the mortification of seeing all our property carried off in different directions, without the least possibility of our preventing it....A cask containing seventy gallons of rum now caught fire and blew up with a terrible explosion; and the wind freshening considerably, huge volumes of smoke and flame burst out in every direction. Two of our houses were so completely enveloped, that we had given up all hopes of saving them..$^{127}$

The visiting tribe that had threatened the attack rushed to the European settlement on seeing the flames, and assisted with the looting. Earle and his compatriots were doing their best to extinguish the fire, but it was a hopeless task. The only ray of hope amid the smoke and charred ruins of some of the houses at Kororareka was the return of Te Whareumu. His people had participated in the looting, and when he discovered his fact, he grabbed a stick and beat some of them so that they would return the stolen items, which they promptly did.

What Earle missed from his detailed account of the fire was the role of some of the local missionaries (whom he had liberally criticised) in bravely trying to preserve his possessions. William Williams, for example, wrote in his journal that immediately upon discovering the fire Mr. Davis $\&$ I went to ascertain the nature $\&$ extent of damage[;] we offered all the assistance in our power on the spot in recovering certain parts of the property $\&$ also to supply them with anything they might stand in need of. Our houses or huts were much on a par with their own - except that ours were larger for the accommodation of our families'. ${ }^{228}$

Richard Davis (1790-1863), whom Williams referred to in this extract, was just as disappointed at Earle's defaming remarks as the other missionaries were who read them. Davis wrote to a colleague that Earle's comments on the missionaries were 'replete with slander and falsehood', and in parts, 'glaringly false', 129 and later gave an even more robust denunciation of the Narrative, and its failure to refer to the missionaries' help during and after the fire, writing that 'Mr. 
Earl [sic], in his work...has held up the New Zealand missionaries to derision. When his house was burned, Mr. Williams and myself were among the first to assist him, and supplied to the full every want he named. Christ's servants are indeed made spectacles to the world. If Mr. Earl has sinned in so writing, the reviewers, the guardians of the reading class in Great Britain, have been partakers of his crime. The day is coming when God will have these mockers in derision. May the Lord bless with true conversion those our bitter persecutors!'130

A decade later, an engraving of a group of Maori recently landed on shore, with their chief giving a speech, appeared in England. The engraving was based on an Earle painting, which in turn was most probably of the landing of the 'hostile' Maori at Kororareka, which he so vividly described in his Narrative. This picture, simply entitled War Speech, ${ }^{131}$ shows around forty Maori seated on the ground on the shore, adjacent to two large war canoes which delivered them to this spot. However, being drawn long after the fact, the image lacks the intensity of Earle's written description of the events of that day. This was something of a pattern in Earle's pictures based on his stay in New Zealand. One explanation for this is that the space in time between the writing of his observations, and his paintings of the associated scenes dulled his memory. Another plausible reason for Earle's paintings of New Zealand lacking the drama of his text in the Narrative is that his book was written for a market that was keen on works packed with action and exciting or even dire situations. Earle's work fits comfortably into this mould, and with himself often portrayed as being at the centre of remarkable events (rather than more on the periphery, where he would be safe and from where he could get a better visual perspective of scenes), the possibility that Earle 'augmented' the dramatic action in his Narrative for commercial imperatives cannot be discarded altogether. 132

One of the buildings that Earle noted escaped serious damage in the fire at Kororareka was a storage house belonging to Te Whareumu, which had recently been converted to a gunpowder depot (its elevated design kept it free of damp). Earle depicted several such elevated storage huts in New 
Zealand, ${ }^{133}$ but $A$ tabood house belonging to Shulitea, Kororadica, Bay of Islands, N. Zealand, ${ }^{134}$ was partly a personal tribute to one of his closest friends in the country, as well as being one of his more morose works.

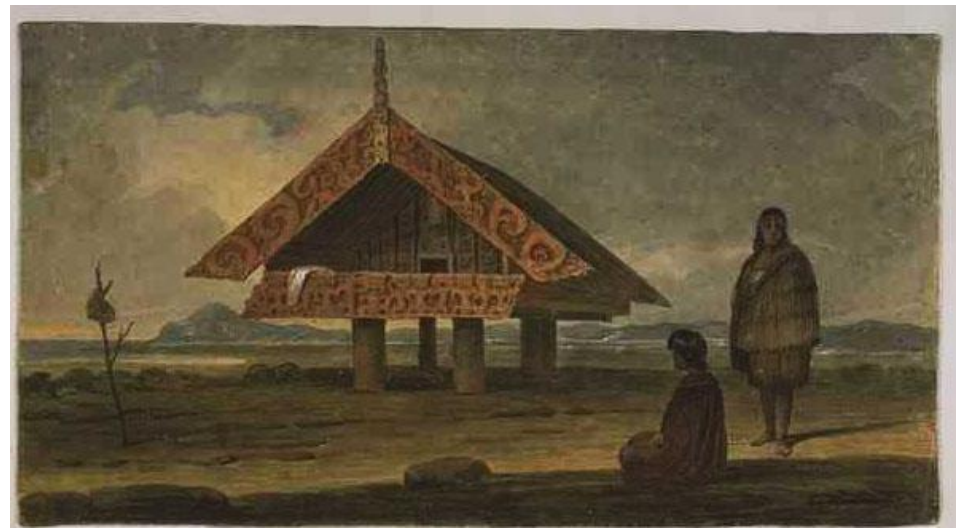

\section{Augustus Earle, A tabood house belonging to Shulitea, Kororadica, Bay of Islands, N. Zealand}

Earle brought in several techniques that contributed to the melancholic mood of this painting. The scene is set at the end of the day, where the light is fading, and where the sun's low angle casts long shadows. The play on light is furthered with the gathering rain clouds in the right half of the background, contrasted with just two areas which Earle permitted to be illuminated: the face of the storehouse and a thin slither of ground, at the end of which is stands a Maori woman. The woman herself, however - like the man sitting on the ground next to her - is partially obscured by the shade, thus drawing the viewer to the storehouse as the most prominent element in the painting.

The intricately carved and lit-up façade of this building has an eerie quality when juxtaposed against the gloomy backdrop. The fact that it is sacred is conveyed to an English viewer not just by the title of the work, but the church-like appearance of this edifice that Earle emphasised. Yet, for all this supposed sacredness, there is a barrenness about the building. The land over which it stands is bare, and there is no 
plant or tree (often symbols of life and regeneration) ${ }^{135}$ visible at all, just a small stick holding up a bag of food off the ground. Moreover, a white blanket or sheet is hanging over the carved base panel, suggesting that the sacredness once associated with this small building has now largely been disregarded.

Following the period of destruction from fire and looters, Te Whareumu began to rebuild Earle's home as a gesture of reconciliation. From being savage beasts, Earle had a momentary change of heart about his hosts. As he sat in his refurnished dwelling, he wrote how 'our time passed on tranquilly, almost every day developing some fresh trait of character amongst these children of nature'.136 The flawed vision of the Noble Savage was being revived in Earle's thoughts. Even when another group of Maori - apparently a war party - were nearing the settlement threatening revenge, all he could see was a romanticised view of this terrifying spectacle: 'The scene was picturesque and exceedingly interesting. It was near the close of a lovely summer's day,the sun fast sinking towards the horizon, threw a warm and mellow glow over the wide expanse of the far-spreading bay, whose smooth waters were only disturbed by the approaching canoe cutting its foamy way. It was crowded with naked warriors, urging their rapid course towards the shore'.137 Despite the approaching threat, Earle was drawn to extract something positive from this warlike display which he saw in all Maori communities he came across. 'If our government should determine to colonise any part of New Zealand', he reflected, 'they would find the natives hardy and willing assistants, and very different from the natives of New South Wales'. ${ }^{138}$

The idea of the Noble Savage, popularised in Europe in the second half of the eighteenth century, ${ }^{139}$ continued to linger in the minds of explorers well into the 1800 s. The view that people in primitive, non-European countries lived in a blissful arcadia had captivated numerous travellers in this period, despite the extraordinary naivety on which the idea was founded. Earle's experience of Maori in New Zealand show him to be at a crossroads in his views about Noble Savages - a 
product of the ambiguity of the age, in which the residue of the idea was beginning to be wiped away by more cynical and certainly more detailed observations of the non-European world.

Earle himself escaped modern urban life in England, which may go some way to suggesting where his sympathies lay. And whereas he found Aborigines to be humans of the 'lowest grade', to Earle, Maori were "cast in beauty's perfect mould", with "the children are so fine and powerfully made, that each might serve as a model for a statue of "the Infant Hercules:" nothing can exceed the graceful and athletic forms of the men, or the rounded limbs of their young women. These possess eyes beautiful and eloquent, and a profusion of long, silky, curling hair: while the intellects of both sexes seem of a superior order; all appear eager for improvement, full of energy, and indefatigably industrious'. ${ }^{140}$

Yet, despite apparently fulfilling the physical ideals of classical antiquity, Earle kept his eyes open to the deficiencies of Maori society, as he saw them - the sort which Henry Williams was too well aware of when he challenged the 'holders of the innocence of savage ignorance [to] come and live among the savages [of New Zealand]', in order to discover the 'ruin' in which they live. ${ }^{141}$

It was not long into his journey in New Zealand before Earle's dreamy impression of Maori society was jolted back to reality, as he conceded in his Narrative: 'It was in the midst of scenes like these that we were passing our time, and I had just become delighted with the appearance of innocence and industry so continually displayed by these people, when I was called upon to witness a sight which exhibited their character in its worst light, and confirmed all my horrible suspicions respecting their alleged cannibalism'. ${ }^{142}$ No amount of goodwill or wishful thinking could overcome Earle's revulsion at evidence of this practice. Europeans travelling to the country had long known of its reputation as a place where cannibalism was practiced, 143 but so repulsive were such acts to British sensibilities that there was still disbelief in some quarters that cannibalism was really a feature of Maori life.

Earle discovered for himself the horror of the practice when Duke rushed to him one morning, having heard from a 
Maori informant that a female slave, whom he names as Matowe, had just been killed, and that her body was being prepared to be cooked and eaten. Duke and Earle decided to visit this scene to witness the fate of the corpse. They took an obscure route to the village, and then suddenly found themselves next to where the preparations were being made for the feast: 'As we approached, we saw evident signs of the murder which had been perpetrated; bloody mats were strewed around, and a boy was standing by them actually laughing: he put his finger to his head, and then pointed towards a bush. I approached the bush, and there discovered a human head. My feelings of horror may be imagined as I recognized the features of the unfortunate girl I had seen forced from our village the preceding evening!'144

Earle found the sight unpleasant in the extreme, but his curiosity was even greater than his revulsion, and he continued to observe the fresh evidence of cannibalism. Next to a fire that had been made to heat the stones used for cooking the flesh, Earle wrote how he saw a man 'preparing the four quarters of a human body for a feast; the large bones, having been taken out, were thrown aside, and the flesh being compressed, he was in the act of forcing it into the oven.... The man completed his task with the most perfect composure, telling us, at the same time, that the repast would not be ready for some hours!'145

Unlike later witnesses, who intervened to prevent acts of cannibalism, or who afterwards tried to thwart any attempts at cooking the flesh, Earle was at pains to emphasise he was in no position to act in such an heroic way. 'As we could not prevent what had taken place', he recalled, 'we were resolved to learn (if possible) the whole particulars'. What he discovered was that Maori knew how disgusted Europeans were with the practice of cannibalism, and how they were thus always anxious to conceal it.

Having then received a short lecture from one of the Maori present on how the human meat was prepared, Earle asked what the girl had done to warrant her being killed in the first place. It turned out that she was guilty of running away from her relatives. The man explaining this then laughed as he recounted how he had shot her through the heart. Earle 'felt 
sick almost to fainting', and gave a depressing description of the cooking that was taking place: 'a hot fetid steam kept occasionally bursting from the smothered mass; and the same dog we had seen with the head, now crept from beneath the bushes, and sneaked towards the village: to add to the gloominess of the whole, a large hawk rose heavily from the very spot where the poor victim had been cut in pieces. My friend and I sat gazing on this melancholy place; it was a lowering gusty day, and the moaning of the wind through the bushes, as it swept round the hill on which we were, seemed in unison with our feelings'. ${ }^{146}$

Those few Maori who had been present gradually wandered off as it would be several hours before all the meat was cooked. Earle's feeling of repugnance was now so intense that as soon as the circumstances allowed, he was finally compelled to take action:

After some time spent in contemplating the miserable scene before us, during which we gave full vent to the most passionate exclamations of disgust, we determined to spoil this intended feast: this resolution formed, we rose to execute it. I ran off to our beach, leaving Duke on guard, and, collecting all the white men I could, I informed them of what had happened, and asked them if they would assist in destroying the oven, and burying the remains of the girl: they consented, and each having provided himself with a shovel or, a pickaxe, we repaired in a body to the spot. [Some local Maori]...had by some means been informed of our intention, and they came out to prevent it. [They]...used various threats to deter us, and seemed highly indignant; but as none of his followers appeared willing to come to blows, and seemed ashamed that such a transaction should have been discovered by us, we were permitted by them to do as we chose. We accordingly dug a tolerably deep grave; then we resolutely attacked the oven. On removing the earth and leaves, the shocking spectacle was presented to our view,- the four quarters of a human body half roasted. During our work clouds of steam enveloped us, and the disgust created by our task was almost overpowering. We collected all the parts we could recognise; the heart was 
placed separately, we supposed, as a savoury morsel for the chief himself. We placed the whole in the grave, which we filled up as well as we could, and then broke and scattered the oven. ${ }^{147}$

This was an audacious act. Earle and Duke were several kilometres away from the nearest European settlement, were unarmed, and without the support of any vessel in the harbour that could have offered them sailors or firepower for protection. In addition, the Maori in the area were all heavily armed. Yet, knowing these circumstances, they had gone ahead and destroyed what this community were looking forward to as a 'national feast'. When a few of the villagers began to return to the site where they thought their meal was being cooked, Earle was forced to confront his impulsiveness. 'After having finished this exploit, and our passion and disgust had somewhat subsided', he wrote after the event, 'I could not help feeling that we had acted very imprudently in thus tempting the fury of these savages, and interfering in an affair that certainly was no concern of ours; but as no harm accrued to any of our party, it plainly shows the influence "the white men" have already obtained over them: had the offence we committed been done by any hostile tribe, hundreds of lives would have been sacrificed'. ${ }^{148}$

It was a victory for civilisation, as Earle saw it, but on returning to Kororareka, he was reprimanded by Te Whareumu, who talked calmly about the affair, but observed that Earle's actions were 'foolish', and that he had put his life at risk. To emphasise the futility of the gesture, Te Whareumu pointed out that after Earle had buried the flesh and fled the scene, the local Maori had dug up the meat again and ate every piece of it. The chief went further, arguing that cannibalism 'was an old custom, which their fathers practised before them; and you [Earle] had no right to interfere with their ceremonies. I myself...have left off eating human flesh, out of compliment to you white men; but you have no reason to expect the same compliance from all the other chiefs'. ${ }^{149}$ It was a subtle reminder to the artist that while British civilisation was making inroads into New Zealand, Maori 
culture and political authority were still dominant throughout the country.

\section{Interest Waning}

For someone who was not only inclined to travel incessantly, but who had spent most of his adult life acting on this inclination, spending too long in a place like the Bay of Islands (where he had become quickly familiar with the community), and with the absence of any buyers of his art (and in all likelihood, anyone even interested in art), Earle began to tire of New Zealand. He wrote how 'after the novelty of our savage life began to wear away, I rambled much about the country, in order to form some judgment of its capability of improvement'. Although he admitted having no specialty knowledge in this area, it was at least something to alleviate his boredom. ${ }^{150}$

Earle's attention now went to the mundane. He wrote about the possibilities of different types of crops growing in New Zealand in the future, and how some of the land seemed ideal for widespread cultivation. Apart from these occasional flickers of interest, he was increasingly bored and looking forward to leaving New Zealand. He described how he had passed some months here, and were beginning to look out for the return of our brig, to take us again into civilised society'. ${ }^{151}$

It is possible that Earle was again running low on art supplies (he knew the enormous frustration this caused from his time marooned on the island of Tristan da Cunha). What stock he had was probably destroyed in the fire in Kororareka, and the fact that many of his New Zealand paintings were produced from sketches, and painted once he had returned to Australia, also points to the scarcity of materials he was experiencing (there was no corresponding shortage of time, however, that would account for him having to leave his painting to a later date).

The only antidote to the monotony of life in the Bay of Islands that Earle was now enduring was the threat of war. By the first days of March 1828, Hongi was at the point of death (he passed away on 6 March), but true to his defiant nature, he expressed a desire to carry out one more glorious 
military campaign before he died. Excited rumours spread throughout the Bay of Islands that he had targets and people in mind, but Earle put these threats down to Hongi's delirium. Even though Hongi still had the means of annihilating Kororareka, his grave illness removed some of the panic that would have gripped the settlement had similar warnings been made even just a few months earlier. There was also some relief from the Europeans in the town that the whaler, the Marianne was in the harbour. As Earle wrote at the time, "The presence of a ship, all over the world, is felt as a protection to Europeans, as in case of danger it is a sure place of refuge'. ${ }^{152}$

As news of Hongi's planned last stand spread, those Maori who felt threatened by him gathered a force together comprising eight canoe-loads of warriors - and landed on the beach at Kororareka in the morning, which was the time of day that they considered that the spectacle of such an arrival could be given its fullest effect. Earle sensed a possible painting in these events: 'I determined to pay them a visit, to witness the ceremonies of the night bivouack, which proved a most picturesque scene, and wild and beautiful in the extreme. Their watch fires glanced upon the dark skins of these finely formed men, and on their bright weapons. Some groups were dancing; others were lying round a fire, chanting wild songs, descriptive of former wars; whilst the graver elders sat in a circle, and discussed the present state of affairs. All were delighted to see me, and each group offered to share their fire and provisions with the "white visitor," as they termed me'. ${ }^{153}$

The scene was certainly an impressive one to Earle. There were almost two hundred muscular warriors, armed, and moving in a tight formation. Earle would have been in dread of this sight had he not known that these men were there to defend, not to attack. A typically loud, ferocious and guttural haka was then performed, after which the warriors felt themselves to be ready for war.

Among the group was a chief whom Earle had befriended in Sydney, and who had stayed at the artist's house there, where Earle had given him a few presents to take back to New Zealand. Never expecting to meet this man again, Earle was 
very pleasantly surprised at seeing him once more, and described the excitement when they renewed their friendship:

The moment I approached he recollected me, jumped up from the "council," ran up to me, hugged me in his arms, and rubbed noses so forcibly with me that I felt his friendship for some time, besides being daubed all over most plentifully with red ochre, which he, being then on a warlike and ceremonious visit, was smeared with from head to foot. When my savage friend (whom we used to call Mr. Tookee) had overcome his first burst of delight at seeing me, and had literally left off jumping for joy, he introduced me to his father, Mr. De Frookee, the chief of this tribe, a very fine specimen of an old New Zealander, who was (I found) highly respected for his integrity and benevolence. His eyes overflowed with tears when he heard I was the person who had shown such kindness to his son at Sydney. I soon felt quite "at home" with the old chief, and experienced the good effect of having kept my word with this uncultivated savage. ${ }^{154}$

When Earle and his Maori acquaintance had first met in Sydney, his friends had laughed at him for entertaining a Maori chief, and for giving him gifts. Now, though, Earle was confident that for that token display of companionship, he now had a staunch ally who would do everything within his means to protect him from danger. Earle's generosity towards chiefs and other important people in Maori society was a mix of personal philanthropy, and an awareness of the need to cultivate goodwill wherever he went. Following an incident when Te Whareumu was snubbed by a visiting British ship causing enormous humiliation to the chief - Earle wrote of the short-sightedness of British Government policies for its ships visiting places such as New Zealand. 'How greatly is it to be regretted', he argued in his Narrative, 'that some arrangements are not made by our government at home, and that there are not orders given to commanders of ships of war touching here, to pay attention to the chiefs, and to make some trifling presents amongst them; for there never were a people more anxious to cultivate a friendly intercourse with British subjects than the inhabitants of New Zealand: and yet there is 
scarcely a government vessel that puts into port here but the natives receive some insult, though they are sent for the express purpose of supporting the dignity of the English nation, and to cultivate the amicable feelings of the chiefs'. 155

Earle had done his bit for race relations with this chief, and after his exchanges were completed, he witnessed various warriors taking their turns at delivering speeches to the assembled force. The engraving of this scene - A New Zealand War Speech ${ }^{156}$ - was published in Earle's Narrative, and was joined by a thorough written description.

A long discussion was now carried on, one speaker at a time occupying the oblong space round which the warriors sat, and the more animated the debate, the faster ran the speaker to and fro, flourishing his hatchet in a most dexterous manner. The instant one speaker finishes, another starts up to answer him; but previous to rising they throw a mat or blanket over their shoulders, and arrange it most tastefully around them; and, as their attitudes are all striking and graceful, and a great part of the figure is left exposed, it forms a study for an artist, well worth his going many miles to witness, and invariably reminded me of the fine models of antiquity.

As a painter, I conceive that this must have been the great secret of the perfection to which the Greek and Roman sculptors brought their works; as they constantly contemplated the display of the human form in all its beauty in their various gymnastic exercises, which enabled them to transfer to marble such ease and elegance as we, living in an age of coats and breeches, never shall be able to rival. ${ }^{157}$

Although the detail of the engraving of A New Zealand War Speech is not of the best quality - even when compared with some of the other engravings in the Narrative - the organisation of the main elements in the picture, together with Earle's use of light, give a sense of drama to the scene. Against a drab backdrop of hills and a few stands of nondescript trees, a group of about sixty armed warriors are seated on the ground in a semi-circle, with the open part of 
the circle closest to the foreground, thus allowing the viewer to almost become a part of the meeting.

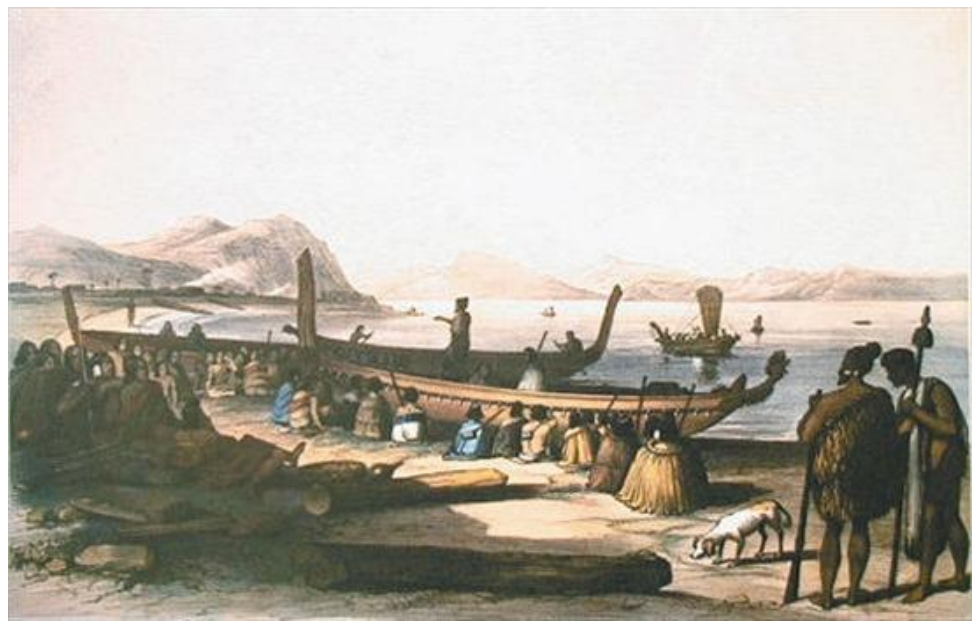

Augustus Earle, A New Zealand War Speech

The focal point of this picture is the chief in the centre of the group. The light illuminates his body, which is posed in a highly theatrical fashion. His arms are outstretched straight, and in one hand he is holding a tewhatewha (a traditional weapon resembling an axe), his legs are astride, and positioned in such a way that his leg muscles appear flexed to their fullest extent, while what looks like a cape is unfurled and waving in the wind over his back. It is a very classical, heroic image transposed to a Maori setting. In different circumstances, it could have been interpreted as a propaganda piece because of the extent to which Earle so obviously glorifies the main subject.

\section{'One of the Finest Panoramas in the World'}

At Christmas, many of the European residents and visitors to the Bay of Islands gathered together to recall memories of home and their families, and to wish each other happiness for the forthcoming year. Earle joined some of his fellow 
countrymen and a few Maori in a shared picnic held in Te Puna (on the Purerua Peninsula in the north of the Bay of Islands), in the vicinity of a small Church Missionary Society mission. Earle described the outing as 'a most delightful trip, the scenery being strikingly beautiful'. His painting of the beach at Te Puna - Tepoanah Bay of Islands, New Zealand, a church missionary establishment ${ }^{158}$ - was a conventional work, with his by-now standard arrangement of a hilly background, a tree framing the scene on one side, and a few houses (this time missionary homes) barely visible in the background. Also, to assist in anchoring this picture to a particular country, Earle placed a Maori man standing in the centre foreground, and three Maori canoes (one of which is full of warriors, paddling frantically).

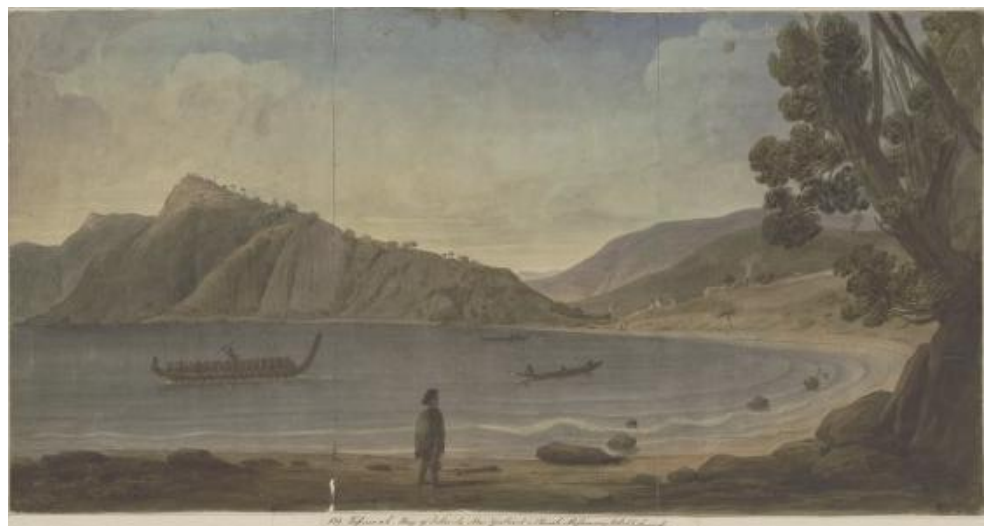

Augustus Earle, Tepoanah Bay of Islands, New Zealand, a church missionary establishment

The European and the Maori worlds were juxtaposed in several respects in this scene. The valley where the picnic was held was overlooked by the Rangihoua $\mathrm{Pa}$, which was positioned 'on the summit of an immense and abrupt hill', 159 and which was presided over by the chief Wharepoaka, ${ }^{160}$ whom William Williams described the previous year as 'a chief of mild manners and great intelligence'.161 This pa had huts that appeared, in many places, 'as though they were 
overhanging the sea', ${ }^{162}$ On visiting the pa, Earle sketched a few scenes, one of which he later made into a painting: $A$ tabood store-house at Range-hue [i.e. Rangihoua] Bay of Islands, New Zealand, ${ }^{163}$ which resembles very closely the composition and atmosphere of A tabood house belonging to Shulitea, Kororadica, Bay of Islands, N. Zealand. Both are melancholic, grim scenes, and were probably influenced by Earle's general impression of New Zealand after he had left the country as much as by the specific settings of these buildings. This much it is possible to be certain of in the case of $A$ tabood store-house at Range-hue because the gloomy ambience (and the warm clothing being worn by the two Maori in the scene) is at odds with the warm sunny weather on the day that Earle visited this location.

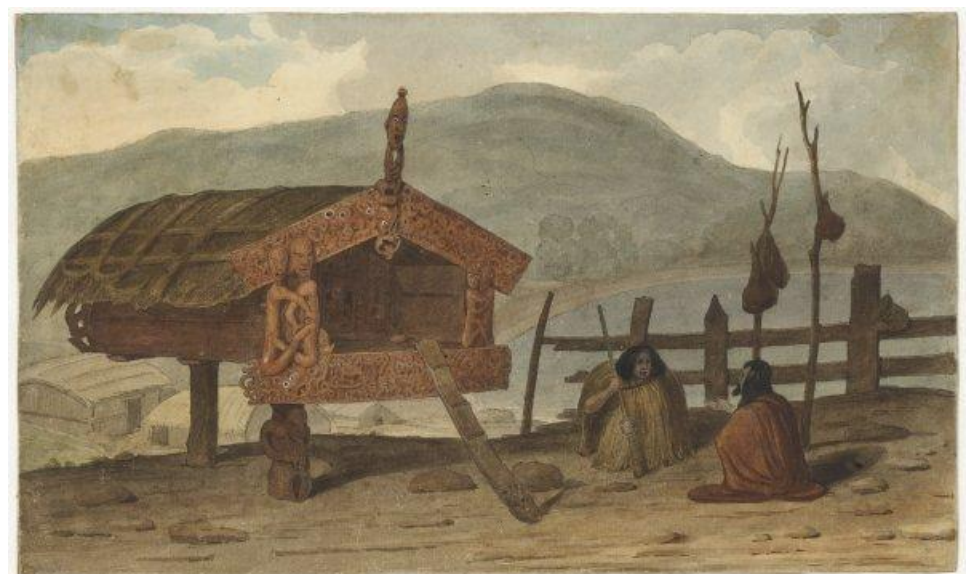

Augustus Earle, A tabood store-house at Range-hue [i.e. Rangihoua] Bay of Islands, New Zealand

In contrast to this indigenous vista, beneath Rangihoua $\mathrm{Pa}$ lay 'a beautiful valley', in which 'the cottages of the missionaries are situated, complete pictures of English comfort, content, and prosperity; they are close to a bright sandy beach: a beautiful green slope lies in their rear, and a clear and never-failing stream of water runs by the side of their enclosures'. As Earle approached, he was 'in an extasy [sic] of delight: such a happy mixture of savage and civilised 
life I had never seen before; and, when I observed the white smoke curling out of the chimneys of my countrymen, I anticipated the joyful surprise, the hearty welcome, the smiling faces, and old Christmas compliments that were going to take place, and the great pleasure it would give our secluded countrymen to meet us, in these distant regions, at this happy season, and talk of our relatives and friends in England'. ${ }^{164}$

Unfortunately, the exhilaration Earle and his comrades were experiencing on arriving at this picturesque location was soon quashed. The missionaries - apparently true to form were unwelcoming. As the boats of men about to celebrate Christmas landed on the shore, Earle was 'crushed' to see the churchmen walk away to their houses, close their gates and doors behind them and gaze at the arrivals through their windows. This behaviour lasted for the entire three days that Earle and his party dwelt in their huts that were just a matter of tens of metres away. Hardly a single word was evidently exchanged between the missionaries and the visitors during this time, according to Earle. 165

What a difference there was when it came to the relations these visitors had with the local Maori. Earle reflected how he 'spent the remainder of the day surrounded by generous savages, who were delighted with our company, and who did every thing in their power to make us comfortable'. Later in the day, two missionaries approached Earle's party, evidently looking for an opportunity to preach to these arrivals, but they were shunned by those Maori who had joined the Christmas celebrations, and who were angry with the missionaries for their unkind behaviour. 166 William Williams had a different interpretation of this meeting, however, and later made a detailed note of the day, after having read Earle's published account of it:

It was I who received this good man [Earle] with his companion Messrs Shand \& Duke, my brother at this time being absent at Hokianga. Having made known his wishes which were to look round for a good view of the Bay, after they had all taken refreshment, I conducted them to a rising ground....Mr. Earl [sic] was delighted 
with the prospect, \& remarked that 'this scenery would make one of the finest panoramas in the world.' The weather was not very favourable. I had therefore a tent pitched for their accommodation \& at dinner time they all partook of that which our houses could afford.....Mr. Earl is therefore altogether incorrect when he states that on his...visit, he met with coldness $\&$ inhospitality. No he was rather piqued because he received no invitation after this, \& could not feel himself at liberty to make our houses his home.

Williams added that one of the reasons why the missionaries were, in general, more remote from Earle than the artist may have preferred had to do with Earle's less firm moral standards: 'we did not feel ourselves bound to introduce to our houses $\&$ our families a man whose habits in life were altogether different from our own'. ${ }^{167}$

Earle's differences with the Anglican missionaries were generally based on personality clashes than on anything more substantial. Earle was certainly not irreligious - his ministering on Tristan da Cunha revealed that - and neither did he make a habit of castigating missionaries. Rather, his comments, as abrasive as they were, were partly a response to the reaction he had received from the missionaries over what they saw as his licentious behaviour. 168 In 1940, the editor of Earle's Narrative, Eric McCormick, published a book ${ }^{169}$ in which he made the following observation relating to the unsettled environment in New Zealand at the time of Earle's visit, and the strength of the artist's character, and how these may have contributed to the animosity towards the missionaries that Earle expressed in his writings:

It is a comment on the contradictions and antagonisms of the small European community of precolonial New Zealand that the man who stands next to Marsden in the hierarchy of New Zealand writers (though far below him) presents the least favourable view of the missionaries. In his Narrative...Augustus Earle never misses a chance of castigating "these pious men", as he terms them, whether for their grudging charity or lack of hospitality, or their self-righteousness, or, worst of crimes, for their obscuring the "finest 
human forms" under clumsy European clothing. For Earle was an artist and viewed the Maoris rather as subjects for sketch and painting than as souls to be retrieved from the dominion of Satan. He describes the beauty of their naked forms, the picturesque disposition of their forces as they landed from their warcanoes....Yet he was no romantic, and having no theoretical axe to grind, he saw not only the heroic side of the people, but also the brutality, the licence, and the insecurity of that stage between the truly primitive and the civilised. Earle was a tolerant, kindly man, blessed with imagination and a sense of fun. ${ }^{170}$

\section{A New Threat}

A few days after the Christmas incident, Earle returned to Kororareka to discover that the powerful chief Titore (Earle spelt it Tetoro) was planning a raid on the settlement, in which Europeans would not be spared. Unlike earlier scares, this was not some rumour that excited the local population but that just as quickly subsided. On the contrary, Titore had sent a herald to Kororareka so nobody would be left with any doubt as to the chief's plans for an invasion.

After the event, Earle painted a portrait of what is presumably this herald (no other is mentioned in his account of his stay in New Zealand), and gave it the ambiguous title knowing the background of his arrival in Kororareka - of Herald or peacemaker; Bay of Islands chief. ${ }^{171}$ As a study of a Maori, it contains enough features for the subject to be identifiable. The clothing, the taiaha, the hair, and the tattooed face all point to this being an indigenous New Zealander. ${ }^{172}$ Strangely, there is nothing threatening in the demeanour of this chief, and no clues in the bland background to hint at anything ominous associated with him. As with many of the other paintings the artist made of New Zealand subjects, the gap between the occurrence of an event or the arrival of a person, and their appearance as a painting, may have been several months, if not years. It also seems that when Earle finally got around to producing these paintings, he made scant if any reference on most occasions to the text that 
was to become the basis of his Narrative, and on which these scenes were loosely based.

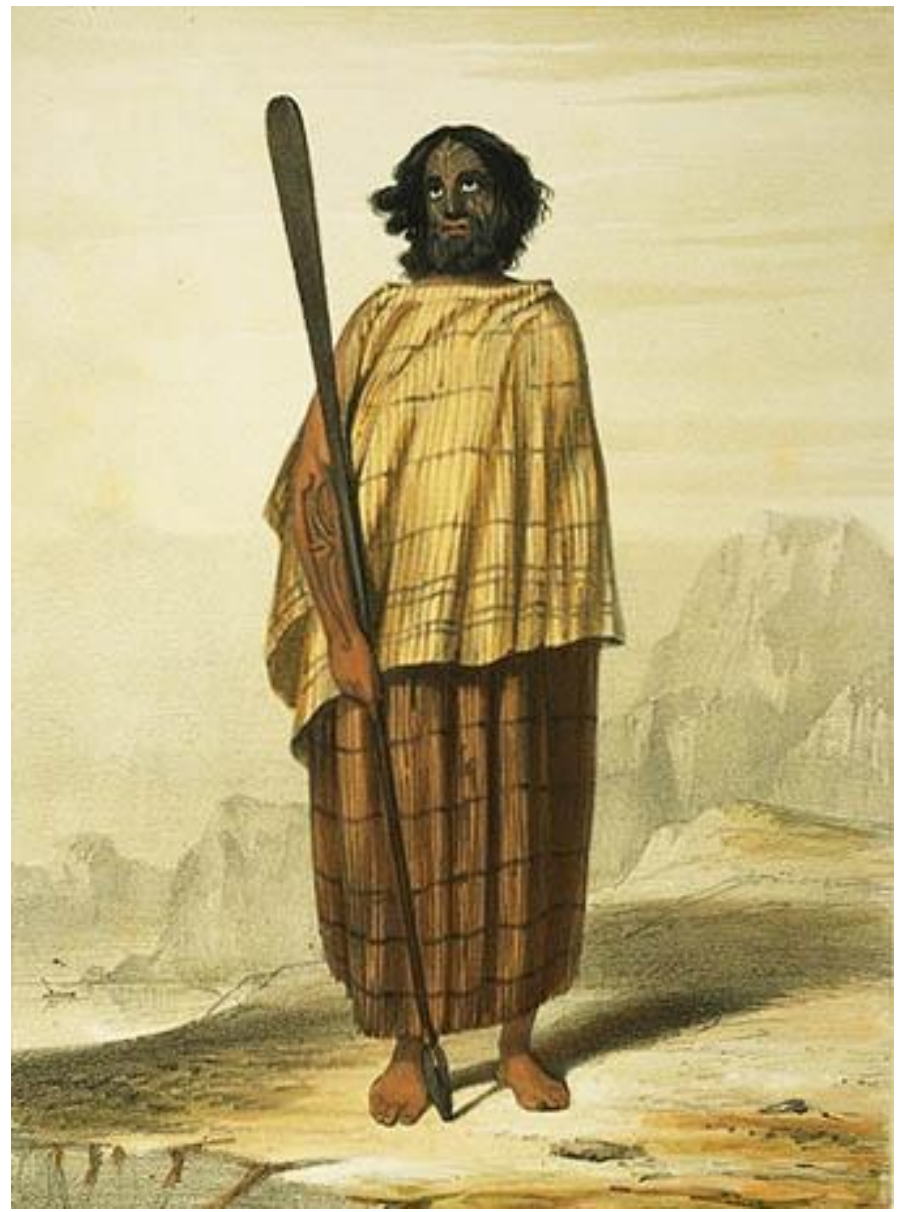

Augustus Earle, Herald or peacemaker; Bay of Islands chief

At the time of the arrival of this herald, however, there was further cause for alarm for the Europeans in the area. Te Whareumu packed up his belongings and his family, and left Kororareka immediately. And neither was there a single ship in the bay at this moment to afford protection through its 
firepower or to offer sanctuary to the local European population - a fact that made Earle even more jittery.

The suspense lasted for several days, and still the dreaded attack did not come. Years later, Earle wrote how, even in the height of this anxious state, he was prepared to explore the area to satisfy his curiosity over the movements of the enemy, and to examine more picturesque spots.173 This sort of bravado might have made him appear more daring in the Narrative, but probably did not reflect his real state of mind or his actions during this crisis.

Earle decided to travel up the Kawakawa River (Earle spelt it Cower-Cower), not so much to explore the location, but more because Te Whareumu and his men had set up a temporary defensive position there, and was consequently a place where Earle would have felt much safer. In this more secure environment, the artist could once again afford to concentrate on nature and not on war. This was a cue for another piece of flowery prose, and an opportunity to suggest to the reader that Earle was not a man easily ruffled by the thought of battle:

At the top of the Bay of Islands, two rivers disembogue, the Wye Catte and the Cower-Cower: they are both small but beautiful streams. It was early in the morning when we started: the dewy mist rose from the unruffled bosom of the river like the gradual lifting up of a curtain, and, at length, displayed its lofty sides, covered with immense trees, the verdure extending to the very edge of the water: all was quiet, beautiful, and serene; the only sounds which broke the calm were the wild notes of the tooe (or New Zealand blackbird [tui]), the splashing of our own oars, or the occasional flight of a wild duck (or shag), disturbed by our approach.

We rowed our boat many miles without seeing the slightest vestige of any human inhabitants or of cultivation: all appeared wild and magnificent as if just fresh from the hands of nature; and it failed not to lead the mind up to the contemplation of the Creator. It seemed utterly impossible to reconcile the idea that such lonely, romantic, and sequestered scenes could conceal hordes of savage cannibals, or that the tranquillity of this very place would soon be exchanged for the noise and tumult of savage warfare. ${ }^{174}$ 
Having glided along the river through this enchanting setting, Earle soon came across Te Whareumu and his men around eight hundred of them - preparing their fortifications for the impending clash with Titore. Still though, despite all the bustle and the apprehension, Earle again was distracted by the attractiveness of this place. He noted that when he 'turned with pleasure to gaze on the beauty of the surrounding country. In a plain, surrounded by high hills, with a beautiful stream of water meandering through it, was situated a group of huts; and many acres of cultivated ground, neatly fenced and cleared, encircled them', and how 'I could almost fancy I was in Italy, and beheld the peasantry at work in their vineyards'. ${ }^{175}$

These fancies of Earle's imagination evaporated when he remembered that he was there for a reason, that reason being the possibility of saving himself from being part of a massacre at the hands of a hostile tribe. He then proceeded to give advice to the designers of the fortifications, telling them where improvements could be made, and what the deficiencies with the existing design were. Earle wrote with pride how those in charge of the building heeded his advice, but it was more likely that they were indulging him while focussing on doing what centuries of accumulated experience had shown was the best way to construct these defences.

Earle had enough time during his short visit to this area to be inspired by, and later paint, a watercolour of a waterfall he came across: The Wye Matte, a waterfall near the KiddyKiddy. ${ }^{176}$ By the time this work was executed, though, Earle was no longer in New Zealand, and indulged in some wishful thinking. The waterfall (now known as the Rainbow Falls on the Kerikeri river), with its surging white flows, is the dominant feature of the picture by virtue of its scale. However, through the placement of light in the scene, Earle focuses the viewers' attention to a Maori woman sitting elegantly on a rock in the foreground, with a European gentleman - possibly Earle (although many of the distinctive markers he typically used to portray himself, such as specific items of clothing in specific colours, are absent). 


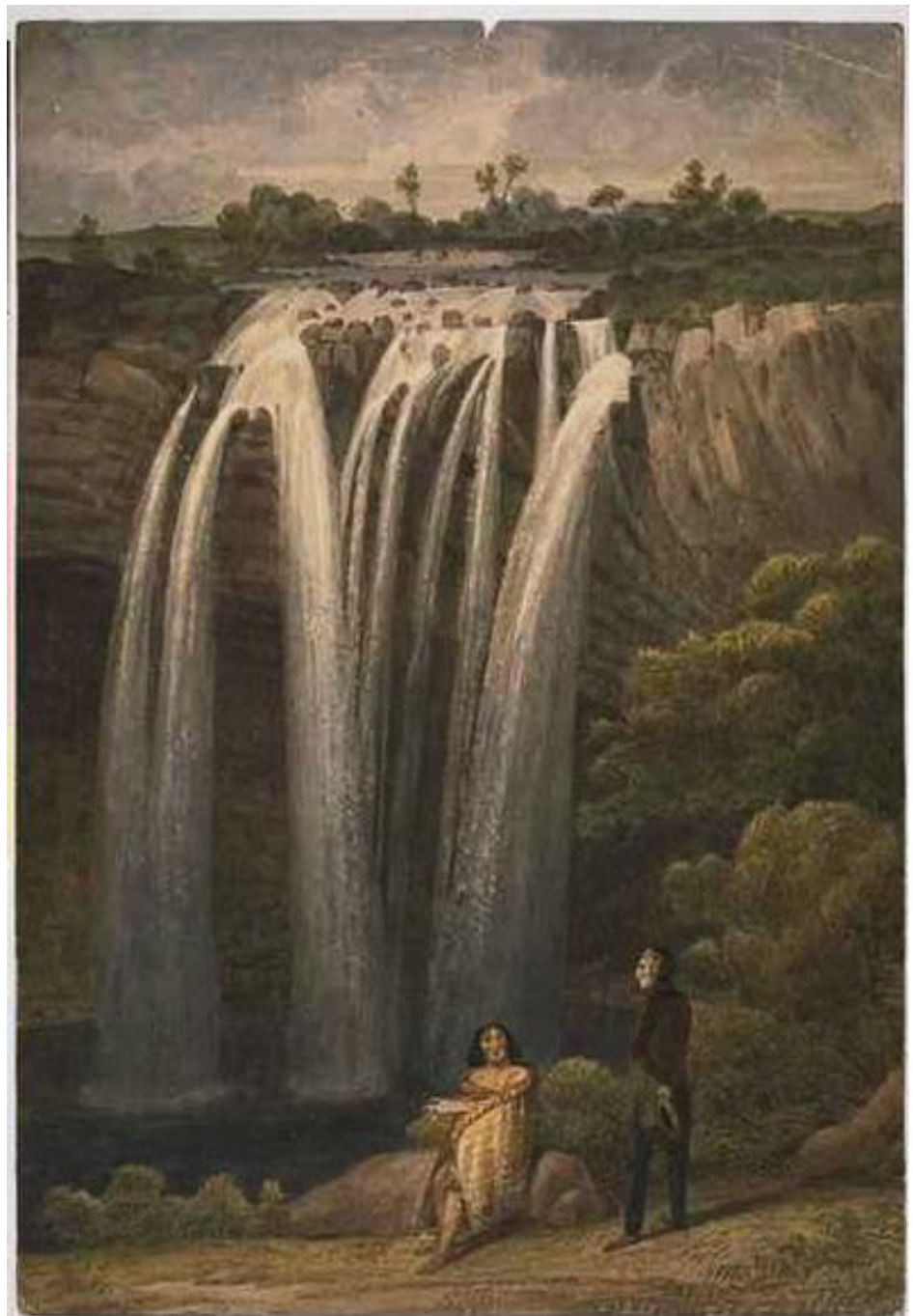

Augustus Earle, The Wye Matte, a waterfall near the Kiddy-Kiddy

The man has his top hat in his hand, and is standing sideways to the viewer, allowing only his face to be lit up by the sun (which is low in the horizon to the left of the frame). The woman, in contrast, is fully illuminated, making her 
appear even more handsome. That the two of them are alone with the man with his hat off and the woman with her lower legs exposed - implies strongly a sense of intimacy in this secluded setting. Moreover, waterfalls in the nineteenth century were frequently used by artists and writers to suggest or emphasise female sexuality, 177 and in The Wye Matte, a waterfall near the Kiddy-Kiddy, the sexual insinuation is reasonably blatant. This is Earle conveying a love scene, but with unconventional twists: it is between a man who is of a different ethnicity from the woman; it is more sexual than romantic; and it is infused with a strong sense of the forbidden, which is achieved principally through the setting. The waterfall is lined on either side with wild bush scene - one of the metaphors common since the eighteenth century for concealment - especially when used in non-European locations. ${ }^{178}$ In addition, the strong light Earle casts on the woman also accentuates the dimness of the surrounding terrain - thus intensifying the sense of the hidden and the prohibited. 179

The woman has her hand outstretched, pointing to the landscape in general, almost as though she is a representative of nature, or even, if this line of thinking is pursued further, a personification of nature. 180 There is also an additional purpose in Earle using this woman as a spectator figure. It represents 'the displaced glance of the picture's real spectator: it is the spectator's painted deputy. By it, it is the act of our seeing that we see. Plausibly posed as a bystander or onlooker to the depicted scene, it yet flagrantly represents us - like it, observers of a scene from which, spatially, we are and must remain implacably separate'. ${ }^{181}$ This was a feature of Western art since early Renaissance times, when Leon Battista Alberti wrote 'I like there to be someone in the narrative painting who tells the spectators what is going on, and either beckons them with his hand to look ... or points to some danger or remarkable thing in the picture'. ${ }^{182}$ In this sense, The Wye Matte, a waterfall near the Kiddy-Kiddy was the latest in this long tradition of spectator figures in landscapes.

While Earle was relieved that he and his companions had a place of refuge, at the back of his mind was the state of his 
house and belongings in Kororareka. However, the threat of a full-scale intertribal war had subsided in his absence, and when Earle returned to his hut, he was pleased to find that none of his possessions had been disturbed. He was even more relieved when a British ship entered the Bay shortly afterwards, which was a source of reassurance if any conflict did erupt thereafter.

\section{'A Token of Respect'}

One morning, after the tension appeared to have lessened, and life had returned to normal, Earle was woken up by the sound of musket fire. He ran outside and saw the firing coming from war canoes which were approaching the beach. The rising apprehension he felt over this spectre diminished when he recognised the party that was arriving was of local warriors, returning from an expedition in Thames. Earle knew that they had been victorious because 'they now returned with quantities of plunder, human heads, human flesh, and many prisoners! After the dance and sham fight had been duly gone through, they proceeded to land their cargo of spoil. First came a group of miserable creatures, women and children, torn by violence from their native homes, henceforth to be the slaves of their conquerors; some were miserably wounded and lacerated, others looked half-starved, but all seemed wretched and dejected'. ${ }^{183}$

As this bounty of war was being offloaded on the beach, Earle noticed that there were no male prisoners. He enquired of one warrior why this was, and was told that all the men from the defeated community had been eaten, with the exception of some of their flesh which had been packed in baskets to be given to friends as presents. The most prized gifts, however, were the preserved tattooed heads. There were a number that were brought on shore, but one was afforded special attention. It was the head of a distinguished chief. Earle observed that 'Most of our people had known him well, and several of his near relations were present: but cruel war seemed to have eradicated every feeling of humanity; for all appeared to contemplate this ghastly object with great satisfaction. These heads were decorated profusely with yellow 
and red ribbons, and with white feathers: they were then stuck upon short poles, and placed, with great ceremony, in front of the old Queen Turero's house; who, sitting at the door, received this token of respect with approval and condescension'. ${ }^{184}$

Earle was disgusted with what he was witnessing, but at the same time, this morbid ritual intrigued him - not for the gruesome artefacts that were being used as gifts, but for what he saw as a community that existed in a state of morality that was entirely different, in this respect, from his own. He decided to create a painting of this scene in order to relay some of the ideas he was ruminating over at this moment. New Zealand warriors, presenting trophies of conquest to their queen, Turero [i.e. Torere], Bay of Islands 185 is Earle's attempt to explore some of these thoughts that the sight of human remains being used as gifts provoked in him.

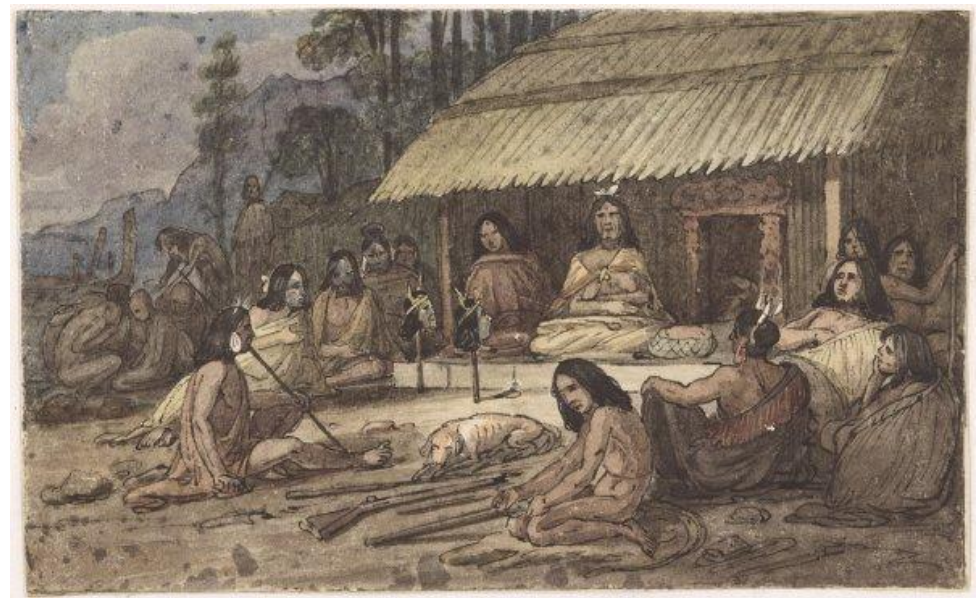

Augustus Earle, New Zealand warriors, presenting trophies of conquest to their queen, Turero [i.e. Torere], Bay of Islands

Gathered around the seated 'queen' are twelve Maori women, all of whom are also on the ground. In the foreground, one of the women - apparently not interested in the proceedings - is lifting a taiaha which forms part of a collection of weapons (including muskets) that lies on the 
earth. Directly in front of the queen are two heads, impaled on short posts stuck into the ground, staring straight at her, while to her side is a basket containing some of the flesh, hacked presumably from the enemy's warriors. Earle wrote how this group 'altogether formed an interesting picture of savage manners, in which ferocity was strongly blended with humanity; for their respect and devotion to the old sybil was manifested as feelingly as their hatred towards those whom they call their enemies: in fact, the young warrior chiefs presenting to her (as was the case with several) their first spoils of conquest, reminded me of young lions bringing part of the spoils of the chase to their aged dam'.186 However, in New Zealand warriors, presenting trophies of conquest to their queen, the warriors (only four are shown) are very much marginalised. They huddle in the left of the picture, poorly defined and obscured by shadows. Their work was done on the battlefield, and during this rite, their role is deliberately made to seem peripheral.

Earle's attitude towards this scene is ambiguous. He repeatedly stated in his Narrative his unqualified repugnance for atrocities such as cannibalism, and in this particular case, he claimed he was full of dread at the possibility of human remains being hauled around Kororareka and used as souvenirs. Yet, at the same time, he remained in the midst of these proceedings in order to gather material for his painting. He justified this by 'hoping that my presence might be some restraint upon their barbarities', 187 but this was more of a feeble pretext, giving him a moral 'free pass' to remain in the vicinity and to study further the subject.

Neither was Earle averse by now at pointing to the local missionaries as bearing some of the responsibility for having failed to advance sufficiently the cause of civilisation among Maori. He wrote (partly in mitigation of his own failure to exert any influence or even utter a reprimand at this scene of the flesh and heads being presented to the queen) that 'It has been imagined that the residence of missionaries would have the effect of civilising the natives...but experience fully proves the fallacy of such an expectation....These people, abstracted by their own gloomy reflections, look with contempt on all who are in the pursuit of "worldly wealth;"....It cannot, therefore, be 
expected that much sympathy can exist between parties, where the cold formality of one excites the contempt and disgust of the other'. ${ }^{188}$

Placing the blame on missionaries for the supposed reluctance by Maori to acclimatise to European moral conventions seems to have been, in part, an attempt by Earle to disguise his own moral ambivalence, or at least, distract readers' attention away from it. It is also possible that Earle found himself balancing his moral concerns over aspects of Maori cannibalism with the need to be able to get close enough to a scene, and for a long enough period, to be able to produce a reliable representation of it in his art. This was sometimes the predicament that artists faced, but for Earle, it was a dilemma that he was at particular pains to justify to others.

\section{Other Interests}

Such was the potency of Maori power all around Earle that he could not avoid consideration of it entering into some of his art. In Distant view of the Bay of Islands, New Zealand, ${ }^{189}$ he took the symbolism of ethnicity and power to the furthest extent of any of his works. On the far right is a pouwhenua - a carved post that was used by Maori communities to demarcate boundaries, and which has a distinct totemic appearance in this painting. The message that this post supposedly signifies control over the land is overt, but Earle challenged the extent of that control by placing himself in the picture as the new totem. ${ }^{190}$ To advance this idea, Earle appears as a stationary figure in the picture (whereas all the Maori in the work are moving), and what is more, Earle is a living symbol, in contrast to the pouwhenua, which is dead and inanimate.

Earle appears in the centre of Distant view of the Bay of Islands, representing the common contemporary view that Europe was at the centre of the world's values and development. ${ }^{191}$ The Maori in this scene, on the other hand, are reduced to spectator figures - a fact Earle accentuates by 'the mainly subservient postures of the natives'192 who are carrying his luggage. And in case this message was not clear enough, Earle's power is further stressed by the fact of his holding a gun, while the Maori in the party are armed only 
with small sticks. The signs of the process of the transfer of power in New Zealand to Europeans are thus both plentiful and explicit in this work.

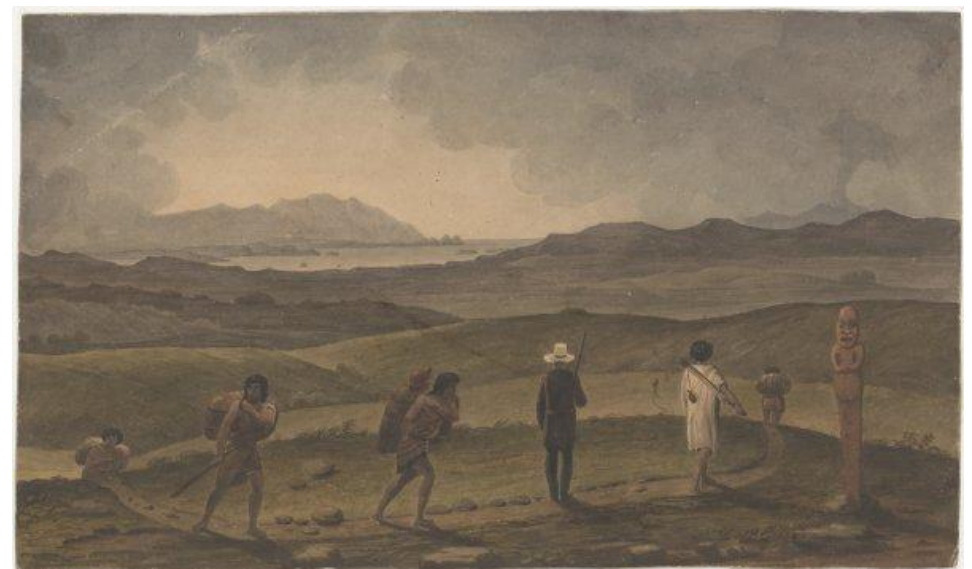

Augustus Earle, Distant view of the Bay of Islands, New Zealand

The art historian Christopher Wilkie has offered a further analysis of Distant view of the Bay of Islands which complements this aspect of the power motif. Wilkie has focussed on the theme of sexual domination in this work, arguing that in the simplification of power to a few strong erectile formations, including his self-portrait and native pouwhenua, in Distant View, Earle may have unconsciously manifested an almost universal language of phallic worship....Earle seems to...posit himself in Distant View as erect, strong and central...and it is likely that he understood the usage of vertical forms to denote power. From a Freudian point of view, these structures are penile replacements, and the penis can denote male power and dominance'. 193

Ironically, Earle's use of phallic imagery to represent power - subconsciously or not - bore a close resemblance to the Maori use of male genitals in carvings as symbols of strength and dominance. ${ }^{194}$ A similar, though more subtle (or perhaps more deeply subconscious) employment by Earle of phallic imagery occurred in Village of Parkuni, River Hokianga.195 Earle's tall figure is in a position of (sexual) dominance, 
'indicated by the recoiled pose of the semi-naked Maori women, the diminishing of the women's private space by Earle...reaching across it, and the rapt gaze of Earle's portrait of the women's faces'. 196 The overt sexuality is partially muted by the panoramic landscape in the background, but this proves only to be a momentary distraction. One of the women on the left of the picture is leaning away from Earle, but with her breasts exposed. According to Wilkie, 'She is conveyed as a sexual delectation for a European gaze'.197

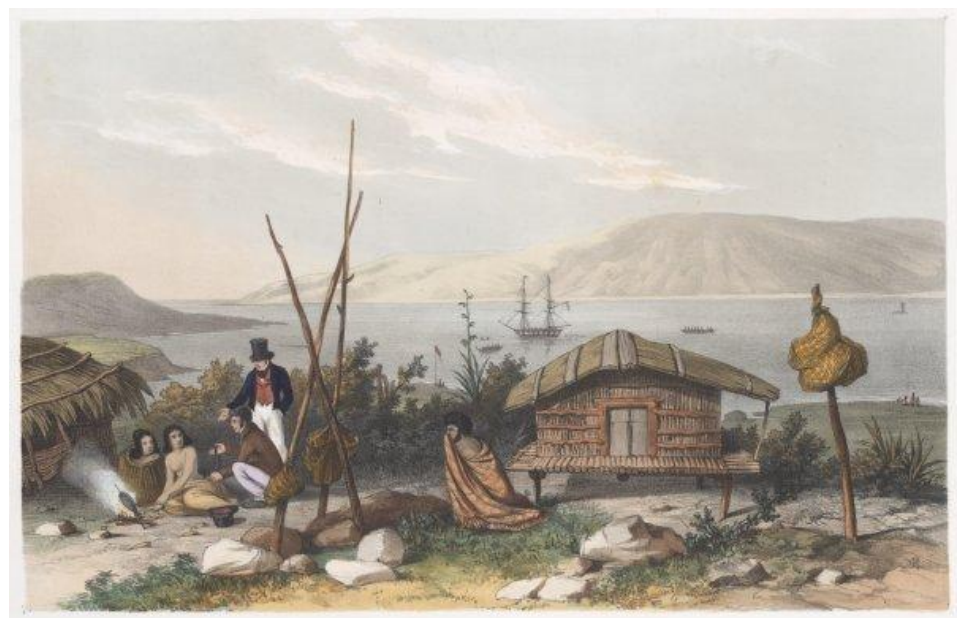

Augustus Earle, Village of Parkuni, River Hokianga

There is a Maori man in this painting, but even though he appears in the centre of the picture, his does not command much of the viewer's attention. $\mathrm{He}$ is almost completely wrapped in a blanket (unlike the exposed women) and looks on at the scene of Earle (and another man, possibly Shand) seducing the women. This suggestion of Maori impotence has political as well as sexual connotations, especially in light of the themes Earle raised in Distant view of the Bay of Islands relating to European dominance over the land and its people. 


\section{'Anxious to Procure More Sketches'}

On 6 March, Hongi passed away, and the Bay of Islands fell into a period of lament (and relief) at his death. For Earle, this came as the end of an era for him. To varying degrees, most of the time he had spent in New Zealand so far had been shadowed by Hongi's presence, either directly, or more commonly, through his influence on the tribal dynamics of the region. Now that the great chief was gone, a power vacuum had been created, and anticipating that this would lead to an interval of instability and even war, Earle decided to return to Hokianga, and from there, to sail to Australia. His companion, Shand, took a brig that was heading to the west coast, but Earle opted to take one final walk across the island 'being still anxious to procure more sketches of this interesting country', and join the brig in Hokianga when it had taken on its cargo of timber. 198

However, even while Earle was packing up all his belongings for the trek to Hokianga, a crisis hit the region, involving numerous Maori factions. As Earle later rather melodramatically put it, 'Bloodshed and devastation stared me in the face from all quarters; and from the state of security I had imagined myself to be in, I was roused to behold myself beset with difficulties'. 199 To make matters worse for Earle, the brig on which Shand was on, and which would have been the securest place to seek refuge, had already left, and so he was stranded in the middle of mounting inter-tribal tension.

The problems grew from a 'trifling circumstance' involving a chief's son being killed for stealing pigs from a neighbouring Maori community. As news of his death circulated, suggestions of war began to be heard from all quarters: "The cry for blood and revenge was universal' as Earle put it, sensing that unlike previous forebodings of war which usually turned out to be false alarms, this was a much more serious situation. 200

Three days later, a breathless messenger arrived at the beach in Kororareka and informed local residents that war had indeed broken out. Earle was shaken by this intelligence, and was further worried when during that night, 'no other sounds were heard than those of agony and woe, the yelling of women, and the shrieks of slaves'. ${ }^{201}$ 
By 13 March, Te Whareumu, Earle's most loyal Maori associate, had been killed - eerily fulfilling a prophesy that Hongi had made on his deathbed. The European population in Kororareka was now nervous as they awaited whatever reprisals they might get caught in the middle of. So in spite of the deep grief Earle felt at the loss of his friend, the dangerous circumstance he was in now demanded all his attention and energies. This was especially the case as on the death of a chief, custom demanded that his family and friends - the latter among which Earle included himself - were open to be plundered and even killed.

Escaping to Hokianga was going to be a big challenge, but there was no alternative. However, the route was lined with potentially hostile tribes, and to make matters worse, Earle had earlier made the decision not to send his luggage in advance of him on the brig, and so would have to make slow progress carrying all his possessions with him as he crossed the island. Further exacerbating the problem was the fact that no Maori, not even the poorest slave, was prepared to offer him any assistance, so fearful were they of the potential for hostilities inland.

Earle had to make a tough decision. In the interests of his personal safety, he was forced to leave almost all his luggage in Kororareka (hopefully to be sent to him at a later date when circumstances allowed) and board the only available ship, the whaler the Marianne, for refuge, and possibly a passage to Hokianga. In the ensuing days, numerous Maori started to converge in the Bay of Islands, and although Earle could have opted for the safety of the Marianne, in a capricious, almost reckless move, he impetuously decided to go back on shore and managed to find a few Maori who would accompany him on the journey to Hokianga, but at enormous financial cost to him because of the risk these Maori were putting themselves at.

When his preparations to depart were complete, Earle said good-bye to his friends in the Bay of Islands - "both civilised and savage' as he put it. Of the surviving first-hand accounts of Earle's travels, this was one of the rare moments when his emotions got the better of him, as he disclosed in his Narrative: 'I felt considerable regret when I found myself really 
going to take a final leave of several native families, with whom I had been on terms of intimacy since my residence here, from whom I had received many proofs of personal regard, and whom, I felt convinced, I should never meet or hear of more: none I regretted parting with more than the family of poor Shulitea; the mere sight of me seemed to rekindle all their grief for the loss of their kinsman, and to remind them more forcibly than ever of his tragical fate. His mother, old Turero, in point of grief, had rivalled Niobe; she had never ceased weeping and lamenting from the time she heard of her son's death, and had twice attempted to strangle herself'. ${ }^{202}$

At daybreak, Earle and his Maori crew left Kororareka by canoe. The only possessions the artist was able to take with him were a small suitcase and his bedding, both balanced in the middle of the canoe. After the days of growing tension and the real fear that he might be engulfed in the coming war, Earle was awash with relief at leaving Kororareka, and in his Narrative, he shows how he suddenly allowed his love of natural scenery to surface again: "The day broke around us with more than usual brightness; the dewy mists of night were just rising from the waters, and the huge and abrupt forms of the mountains were beginning to develope [sic] themselves; flights of wild ducks and stray birds skimmed rapidly by us. The thoughts that crowded my mind were strange and varied, while contemplating scenes of such tranquil beauty as were now presented, glowing with the tints of the rising sun'.203

That day, Earle and his crew travelled as far as Kerikeri. In the afternoon, they met with the local missionaries, whom the artist found were in the greatest consternation and dismay' because of news of the fighting at Hokianga - the place Earle had as his destination. He was now more worried than ever, and wrote:

I earnestly requested them to inform me candidly, from all they had heard, whether they thought I might, with safety, venture across the country; but I could get nothing from them but vague and mysterious answers: one thing, however, they made me very clearly understand; which was, that they neither cared for me nor for my drawings; that their own safety engrossed all 
their thoughts; and that a worldly-minded, misguided creature like me was but as dust in the balance, compared to such godly people as themselves, who were now placed in jeopardy. They, without scruple, applied quotations from the Scriptures to themselves; such as "Why do the heathen so furiously rage," \&c. \&c.

My necessities compelled me to request a favour from them; which was, that they would allow one of their boys, who could speak English, to accompany me, as our loads were heavy; and his being known to belong to their establishment I thought might be some protection; but the short answer of the monosyllable "No" soon made me repent having asked it. ${ }^{204}$

Earle had set aside his dislike for the missionaries in order to try to get some assistance from them, but their narrowmindedness seemed only more constricted by events, and Earle was consequently even more disappointed in these preachers of the Gospels.

Without any offers of support from the missionaries, the next morning, Earle and his Maori helpers set off, with the artist still deeply annoyed at the inhospitable treatment he had received from his hosts. Even as he was leaving, he noted how they 'never even enquired whether I had any provision for a journey they themselves would not have dared to undertake'. Asking a favour of these people was out of the question, as Earle observed when looking over the poor state of his footwear: 'As my shoes were nearly worn out, and I had a long distance to go, over execrable roads, I had intended asking them for a new pair, as they had abundance of every thing of the kind sent to them from England, to distribute to the needy (and I fully came under that description of character); but finding them so selfish and cold-hearted, and meeting with one refusal, I refrained, and set off, literally almost barefooted'.205

The journey was a tough one. In addition to having to carry his personal possessions and a supply of food, Earle and every other member of his party had to take muskets, powder and shot with them. He was also worried that if they encountered even the slightest sign of hostility, his Maori companions would 'slip off their burdens, make their escape, 
and leave me and my baggage to my fate; which the missionaries had told me they considered a thing very likely to happen'. ${ }^{206}$

When Earle arrived at the village of the chief Patuone, there were more signs that the region was unsettled. He had previously visited this settlement, but now, all appeared very different. 'Instead of the tumult I had formerly heard', he noted at the time, 'all was silence; the numerous families then there, all fully occupied, were exchanged for a few old surly-looking slaves, and the huts were all deserted. The inhabitants, in consequence of the rumour of approaching war, having betaken themselves to one of their fortified pars [sic]'. Earle had no alternative but to spend the night with what he termed 'these suspicious-looking creatures', who, over the course of that evening, did everything they could to make the artists fearful. As a result, he 'passed a most miserable night, nearly suffocated with smoke, distracted with their noise, and annoyed by vermin of every description'. ${ }^{207}$

Sunrise the next morning was all the excuse Earle needed to leave this village and continue with his journey to Hokianga. Along the route, he found plenty of evidence of recent fighting: 'villages, which had been crowded, were now entirely desolate, and, in many instances, burned to the ground. On that spot where I had left a party of enterprising Scotchmen busily employed in sawing timber, with crowds of natives assisting them, all was quiet and totally deserted, with the exception of a few nearly starved, wretched-looking dogs, who, hearing some one approach, came out, and tried to bark at us, but were too weak to utter a sound'.208 Strangely, Earle did not appear to make even one sketch of these scenes which he obviously found so haunting. It is possible that he was under such urgency to get to Hokianga that he did not have the time, but when he returned to Sydney and when he had more than enough time to paint such vistas, he chose to focus instead on other scenes from his New Zealand visit.

That evening, Earle arrived in Hokianga and found the European settlement there surrounded by Maori who had fled the fighting in neighbouring regions. This was a dangerous situation, because it made the settlement a target for those Maori who were still on the warpath. The settlers had fortified 
their community to the best of their means, but Earle felt the act of building fortifications and mounting guns was a dubious one, on the basis that it might antagonise any hostile Maori approaching the settlement, and encourage them to attack the Europeans, rather than seeing them as a neutral party.

For a week, the European residents of Hokianga huddled behind their defences, ever watchful for the smallest sign from the surrounding bush that an attack was imminent. It was only with the appearance of the Wesleyan missionary John Hobbs, who had arrived in the area to establish a base at nearby Mangungu, that new intelligence about the military and political situation in the region was delivered. He advised the anxious Europeans at Hokianga that a meeting of all the affected chiefs in the area had been held, and after much heated debate, a consensus was reached that the fighting would stop, mainly because it was in no-one's interests to continue. Peace quickly returned to Northland.

\section{Departure}

On 14 April 1828, with the brig at Hokianga fully loaded with its cargo of timber, flax, and potatoes, Earle went on board, ready for the journey back to Sydney. However, just as it moved out into the harbour, a strong storm arrived and lashed the vessel so forcefully that one of the cables holding it to shore snapped. As a result, the ship spent two days being tossed around in the harbour in heavy seas.

The storm eventually subsided, but after that, the winds were not favourable, and for the next week, Earle remained on the ship as it lay still in the harbour. During this delay, the crew and passengers on board were kept company by Maori who called on them frequently, as Earle noted with some irritation: 'We were visited daily by parties of natives, who seemed to rejoice at our being delayed, as it gave them more of our company than they had calculated upon. They were more delighted with our society than we were with theirs: in a small vessel they are a serious nuisance, on account of the swarms of vermin they bring with them, and which they communicate liberally to all. Myself and all the passengers on board had our 
leisure time fully occupied in dislodging these "little familiars" from their strong-holds in different parts of our apparel'.209

Finally, on 21 April,210 with a 'fair wind and smooth sea', the captain of the brig announced that the departure was imminent. Final preparations were made, and the Maori on board departed - something that produced a strong emotional response from Earle, despite having described them as a nuisance just a few days earlier: 'When the moment of separation came, it caused a great deal of emotion on both sides. I must confess I felt much affected when I came to rub noses, shake hands, and say "Farewell" to these kind-hearted people. I saw them go over the ship's side, and reflected that I should never behold them more. There is always something repugnant to our feelings in the idea of separating from any being for ever; and as, in this instance, I felt assured that this was our last time of meeting, it cast a gloom over the pleasure the fair wind and smooth sea would otherwise have afforded me. As we fell down towards the river's mouth, and, indeed, as long as their canoes were to be seen, they kept waving their hands towards us'. ${ }^{211}$

Earle had finally concluded his New Zealand visit. He had arrived in the country 'with feelings of fear and disgust', and had anticipated only a short stay in order to find some new subjects to draw. By the time of his departure, however, his view of New Zealand and its indigenous inhabitants had matured: 'I left them with opinions, in many respects, very favourable towards them. It is true, they are cunning and overreaching in trade, and filthy in their persons. In regard to the former, we Europeans, I fear, set them a bad example; of the latter, they will gradually amend. Our short visit to Ko-ro-radi-ka greatly improved them in that particular. All took great pains to come as clean as possible, when they attended our "evening tea-parties." In my opinion, their sprightly, free, and independent deportment, together with their kindness and attention to strangers, compensate for many defects'.212 


\section{Notes}

1 A. Ward, A Show of Justice: Racial Amalgamation in Nineteenth Century New Zealand, Toronto, 1974, p. 90; W. M. Robbins, 'Macquarie, Marsden and the Sunday Muster Dispute: Some thoughts on the role of religion and the management of convict workers', in B. Pocock, C. Provis, and E. Willis (eds.), High Road or Low Road, South Australia, 2006, p. 463.

$2 \quad$ The Monitor, 25 October 1827.

3 A. Earle, A Narrative of Nine Months' Residence in New Zealand in 1827; Together with a Journal of a Residence in Tristan D'Acunha. An Island Situated Between South America and the Cape of Good Hope, p. 1.

4 Ibid., p. 2.

5 C. O. Davis, The Life and Times of Patuone, The Celebrated Ngapuhi Chief, Auckland, 1876, pp. 44-6.

6 Like most attempts at writing Maori at this time, there was variance in the spelling. Earle, for example, wrote Hokianga as 'E. O. Ke Anga', and Whangaroa as 'Wangha Roar'.

7 Hobbs wrote the date of arrival as 31 October. See J. Hobbs, Diary, transcript, ms 144, Auckland Institute and Museum Library,

8 A. Earle, A Narrative of Nine Months' Residence in New Zealand in 1827; Together with a Journal of a Residence in Tristan D'Acunha. An Island Situated Between South America and the Cape of Good Hope, pp. 8-11.

9 L. Head, The Pursuit of Modernity in Maori Society: The Conceptual Bases of Citizenship in the Early Colonial Period', in A. Sharp and P. McHugh, Histories, Power and Loss: Uses of the Past - A New Zealand Commentary, Wellington, 2001, p. 99.

10 Rex Nan Kivell Collection; NK12/67, National Library of Australia.

11 A. Earle, A Narrative of Nine Months' Residence in New Zealand in 1827; Together with a Journal of a Residence in Tristan D'Acunha. An Island Situated Between South America and the Cape of Good Hope, pp. 13-14.

12 C. Baxter, An Irresistible Temptation: The True Story of Jane New and a Colonial Scandal, Sydney, 2006, p. 357.

13 A. Earle, A Narrative of Nine Months' Residence in New Zealand in 1827; Together with a Journal of a Residence in Tristan D'Acunha. An Island Situated Between South America and the Cape of Good Hope, p. 15. Doubts over whether this was actual evidence of cannibalism, and the nature of Earle's 'eye-witness' accounts, appear in L. Wevers, Country of Writing, Travel Writing and New Zealand 1809-1900, Auckland, 2002, pp. $81 \mathrm{ff}$.

14 Ibid., p. 18.

15 Ibid., pp. 18-20.

16 Rex Nan Kivell Collection; NK12/81, National Library of Australia. 
17 A. Earle, A Narrative of Nine Months' Residence in New Zealand in 1827; Together with a Journal of a Residence in Tristan D'Acunha. An Island Situated Between South America and the Cape of Good Hope, pp. 21-2.

18 Ibid., p. 26.

19 R. Nairn, 'The Early History of Horticulture in New Zealand', in Journal of the New Zealand Institute of Horticulture, vol. 3, no. 2, supplement, 1932, pp. 1-20.

20 J. McAloon, 'Resource Frontiers, Environment, and Settler Capitalism, 1769 - 1860', in E. Pawson and T. Brooking (eds.), Environmental Histories of New Zealand, South Melbourne, 2002, p. 59.

21 Rex Nan Kivell Collection; NK12/138, National Library of Australia.

22 Rex Nan Kivell Collection; NK12/137, National Library of Australia.

23 A. Earle, A Narrative of Nine Months' Residence in New Zealand in 1827; Together with a Journal of a Residence in Tristan D'Acunha. An Island Situated Between South America and the Cape of Good Hope, pp. 25-6.

24 Earle's early New Zealand paintings may have been destroyed in a fire in Kororareka which occurred while he was there, thus requiring a second set of drawings. See The Monitor, 10 May 1828; A. Earle, A Narrative of Nine Months' Residence in New Zealand in 1827; Together with a Journal of a Residence in Tristan D'Acunha. An Island Situated Between South America and the Cape of Good Hope, p. 93ff.; H. E. Spencer, Augustus Earle: A Study of Early Nineteenth-Century Travel Art and its Place in English Landscape and Genre Traditions, p. 222.

25 Patuone later acquired the nick-name 'Te Wheke' (the Octopus) on account of his alleged duplicity (hence the reference to several hands).

26 A. Earle, A Narrative of Nine Months' Residence in New Zealand in 1827; Together with a Journal of a Residence in Tristan D'Acunha. An Island Situated Between South America and the Cape of Good Hope, p. 32.

27 Appears as a coloured lithograph in A. Earle, Sketches Ilustrative of the Native Inhabitants and Islands of New Zealand, R. Martin \& Co, in Rex Nan Kivell Collection; NK668, National Library of Australia.

28 Although it could possibly be Shand.

29 A. Earle, A Narrative of Nine Months' Residence in New Zealand in 1827; Together with a Journal of a Residence in Tristan D'Acunha. An Island Situated Between South America and the Cape of Good Hope, p. 38.

$30 \quad$ Ibid. p. 39.

31 Ibid., pp. 40-1. 
32 Art. III, 'Earle's Account of New Zealand', in Edinburgh Review, p. 334.

33 Ibid., pp. 343-4.

34 W. Williams to Secretary, Church Missionary Society, in H. E. Spencer, Augustus Earle: A Study of Early Nineteenth-Century Travel Art and its Place in English Landscape and Genre Traditions, p. 249.

35 'Earle's Residence in New Zealand', in The Eclectic Review, third series, vol. 8, July-December 1832, p. 241.

36 Op. cit.

37 E. Stokes, 'Contesting Resources: Maori, Pakeha, and a Tenurial Revolution', in E. Pawson and T. Brooking (eds.), Environmental Histories of New Zealand, South Melbourne, 2002, p. 40.

38 A. Earle, A Narrative of Nine Months' Residence in New Zealand in 1827; Together with a Journal of a Residence in Tristan D'Acunha. An Island Situated Between South America and the Cape of Good Hope, pp. 125-6.

39 Ibid., p. 146. Earle also noted that 'At length we discovered that their [Maori] cunning was as conspicuous as their politeness. They had observed we generally lay longer in bed on a Sunday morning than any other; they accordingly were up by break of day, and had completed many hours' work before we made our appearance; but the moment one of us did appear, the work was instantly left off. This degree of outward respect, though craftily managed, was infinitely more than could be reasonably expected from a rude and turbulent savage. It is more respect than we Europeans pay to any religious ceremony we do not understand. Even their taboo'd grounds would not be so respected by us, if we were not quite certain they possessed the power instantly to revenge any affront offered to their sacred places'. Ibid., p. 147.

40 Ibid., pp. 154-5.

41 Ibid., pp. 155-6.

42 Ibid., pp. 41-2.

43 Ibid., p. 49.

44 Ibid., pp. 51-3.

45 Ibid., pp. 53-4.

46 J. Sissons, W. W. Hongi, P. Hohepa, Nga Puriri o Taiamai: A Political History of Nga Puhi in the Inland Bay of Islands, Auckland, 2001, pp. 43-5.

47 A. Earle, A Narrative of Nine Months' Residence in New Zealand in 1827; Together with a Journal of a Residence in Tristan D'Acunha. An Island Situated Between South America and the Cape of Good Hope, p. 56.

48 Although several sketches and engravings of chiefs were made as early as the time of Cook's voyages in the 1760s and 1770s. Sainson's Maori perform a haka on board Dumont D'Urville's Astrolabe at Tolaga Bay, 1827, is another early example, Reference: 1/2-096081, Alexander Turnbull Library. Also see 
especially, J. Barry, The Rev Thomas Kendall and the Maori chiefs Hongi and Waikato, 1820, Reference number: G-618, Alexander Turnbull Library.

49 Rex Nan Kivell Collection; NK12/84, National Library of New Zealand, National Library of Australia.

50 For details on the nature of this trade in women, see T. Fitzgerald, 'Jumping the Fences: Maori women's resistance to missionary schooling in northern New Zealand 1823-1835', in Paedagogica Historica, vol. $\underline{37}$, issue $\underline{1}, 2001$, pp. 175ff.; A. P. Vayda, 'Maori Prisoners and Slaves in the Nineteenth Century', in Ethnohistory, vol. 8, no. 2, Spring, 1961, pp. 144-155; K. Rountree, 'Re-making the Maori Female Body: Marianne Williams's Mission in the Bay of Islands', in Journal of Pacific History, vol. 35, no. 1, June 2000, pp. 49-66; For specifics relating to the period Earle was in New Zealand, see The Monitor, 10 May 1828.

51 Rex Nan Kivell Collection; NK12/71, National Library of Australia.

52 'Here, on a beautiful bank', Earle wrote about his approach to this mission, "with a delightful beach in front, and the entrance of the bay open to them, the clear and blue expanse of water speckled over with fertile islands, reside these comfortable teachers of the Gospel', wrote Earle. A. Earle, A Narrative of Nine Months' Residence in New Zealand in 1827; Together with a Journal of a Residence in Tristan D'Acunha. An Island Situated Between South America and the Cape of Good Hope, p. 58.

53 A. Earle, A Narrative of Nine Months' Residence in New Zealand in 1827; Together with a Journal of a Residence in Tristan D'Acunha. An Island Situated Between South America and the Cape of Good Hope, pp. 58-9.

54 Ibid., p. 59.

55 Ibid., pp. 60-1.

56 L. M. Rogers (ed.), The Early Journals of Henry Williams, Senior Missionary in New Zealand of the Church Missionary Society, 18261840, Christchurch, 1961, p. 89.

57 The Monitor, 10 May 1828.

58 H. Williams, in L. M. Rogers (ed.), The Early Journals of Henry Williams, Senior Missionary in New Zealand of the Church Missionary Society, 1826-1840, p. 363.

59 The Monitor, 6 December 1827.

60 This year is provided in PIC. U5495 NK739, LOC NL shelves 40, National Library of Australia

61 Rex Nan Kivell Collection; NK12/75, National Library of Australia.

62 M. Dunn, A Concise History of New Zealand Painting, Auckland, 1991, p. 11.

63 PIC. U5495 NK739, LOC NL shelves 40, National Library of Australia.

64 For details on the development of panoramas, see M. Wood, 'The Mountain Panorama and Its Significance in the Scottish Context', in Cartographica: The International Journal for Geographic 
Information and Geovisualization, vol. 38, nos. 1-2, SpringSummer 2001, pp. 103-118; J. T. Schnapp, 'The Mass Panorama', in Modern/Modernity, vol. 9, no. 2, 2002, pp. 242-81.

65 As an indication of the scale of some of the works exhibited at this location, one panorama, of the Battle of Trafalgar, covered 930 square metres of canvas. See 'The Battle of Trafalgar', Leicester Square, PAF4742, National Maritime Museum, Greenwich, London. Also see Mogg's New Picture of London and Visitor's Guide to it Sights, London, 1844.

66 Apart form the mention of its exhibition in the editor's introduction to Earle's Narrative. A. Earle, A Narrative of Nine Months' Residence in New Zealand in 1827; Together with a Journal of a Residence in Tristan D'Acunha. An Island Situated Between South America and the Cape of Good Hope, pp. vii-viii.

67 The same details that were contained in The Monitor about Earle's first few days in the Bay of Islands and the panorama he supposedly produced were repeated in The Australian, but with the additional note that Earle was planning to travel to the Solomon Islands on the Governor Macquarie, and that he intended to visit Tongatabu [sic] and Tikopia. However, New Zealand captivated the artist maybe more than he initially realised, and he decided to forestall further travel overseas until he had explored more of the country he was presently in. The Australian, 12 December 1827.

68 Rex Nan Kivell Collection; NK1106, National Library of Australia. The catalogue notes state that this painting was copied form a plate 'copied from a plate in: A narrative of a nine months' residence in New Zealand in 1827 / by A. Earle. London, 1832'.

69 Very similar elements appeared, for example, in The residence of Shulitea chief of Kororadika Bay of Islands, New Zealand, Rex Nan Kivell Collection; NK12/71, National Library of Australia.

70 A. Earle, A Narrative of Nine Months' Residence in New Zealand in 1827; Together with a Journal of a Residence in Tristan D'Acunha. An Island Situated Between South America and the Cape of Good Hope, pp. 137-9.

71 M. Neill, 'From the Editor', in Shakespeare Quarterly, vol. 52, no. 4, 2001, p. v; H. Robley, Moko; or Maori Tattooing, London, 1896, pp. 5ff; A. Kaeppler, Cook Voyage Provenance of the 'Artificial Curiosities' of Bullock's Museum', in Man, New Series, vol. 9, no. 1, March 1974, pp. 68-92; H. L. Roth, 'Maori Tatu and Moko', in The Journal of the Anthropological Institute of Great Britain and Ireland, vol. 31, 1901, pp. 29-64.

72 C. Palmer and M. L. Tano, Mokomokai: Commercialisation and Desacrilisation, Colorado, 2004, pp. 4-6; P. Walsh, Art. LXX.Maori Preserved Heads', in Transactions of the Auckland Institute, 1 October 1894, pp. 610-34.

73 Rex Nan Kivell Collection; NK12/66, National Library of Australia. 
74 Rex Nan Kivell Collection; NK12/96, National Library of New Zealand.

75 Judging by the small scale of the market in Sydney at this time.

76 A. Earle, A Narrative of Nine Months' Residence in New Zealand in 1827; Together with a Journal of a Residence in Tristan D'Acunha. An Island Situated Between South America and the Cape of Good Hope, p. 62.

77 Ibid., p. 62-3.

78 Ibid., pp. 64-5.

79 Ibid., pp. 64-5.

80 Ibid., p. 66.

81 The work is of a fine quality, and was patiently executed - not the sort of work that would easily have been made in the rough confines of the Bay of Islands. Also, Earle mentions specifically the fact that he made only sketches of this scene, so he obviously intended to leave the full painting to a later date. See op. cit.

82 The Monitor, 10 May 1828.

83 Drawings Paintings and Prints Collection, Reference: G-707, National Library of New Zealand.

84 M. Dunn, New Zealand Painting: A Concise History, Auckland, 2004, p. 25.

85 A. Earle, A Narrative of Nine Months' Residence in New Zealand in 1827; Together with a Journal of a Residence in Tristan D'Acunha. An Island Situated Between South America and the Cape of Good Hope, p. 65.

86 M. Dunn, New Zealand Painting: A Concise History, p. 25.

87 Op. cit.

88 R. Davis, in J. N. Coleman, A Memoir of the Rev. Richard Davis, for Thirty-Nine years a Missionary in New Zealand, London, 1865, p. 84.

89 G. Docking, Two Hundred Years of New Zealand Painting, Wellington, 1980, p. 24.

90 Rex Nan Kivell Collection; NK668, National Library of Australia. The catalogue notes states: 'Earle, Augustus, 1793-1838. Sketches illustrative of the native inhabitants and islands of New Zealand. R. Martin \& Co., London'.

91 D. L. Cloher, Hongi Hika: Warrior Chief, Auckland, 2003, pp. 2779.

92 There could be no artistic reason for replicating the initial painting.

93 A. Earle, A Narrative of Nine Months' Residence in New Zealand in 1827; Together with a Journal of a Residence in Tristan D'Acunha. An Island Situated Between South America and the Cape of Good Hope, pp. 156-7.

94 D. Urlich Cloher, Hongi Hika: Warrior Chief, Auckland, 2003, pp. 277-9.

95 A. Earle, A Narrative of Nine Months' Residence in New Zealand in 1827; Together with a Journal of a Residence in Tristan D'Acunha. 
An Island Situated Between South America and the Cape of Good Hope, pp. 67-9.

96 Ibid., p. 70.

97 Rex Nan Kivell Collection; NK668, National Library of Australia. The catalogue record notes: 'London (26 Long Acre): Lithographed \& Published by R. Martin \& Co., [1838]'.

98 A. Earle, A Narrative of Nine Months' Residence in New Zealand in 1827; Together with a Journal of a Residence in Tristan D'Acunha. An Island Situated Between South America and the Cape of Good Hope, p. 70.

99 Rex Nan Kivell Collection; NK12/82, National Library of Australia.

100 Rex Nan Kivell Collection; NK12/83, National Library of Australia.

101 This was the correct direction for outstretched tongues to point in haka. Some early engravings of Maori have the tongue reaching out in various directions, but the downward angle was traditionally the only permissible one.

102 Engraving in A. Earle, A Narrative of Nine Months' Residence in New Zealand in 1827; Together with a Journal of a Residence in Tristan D'Acunha. An Island Situated Between South America and the Cape of Good Hope, p. 70a.

103 See, T. Fitzgerald, 'To unite their strength with ours', in Journal of Pacific History, vol. 39, issue 2, September 2004, p. 150; R. Firth, 'Maori Hill-forts', in Antiquity, vol. 1, no. 1, 1927, p. 66.

104 Rex Nan Kivell Collection; NK12/141, National Library of Australia.

105 Rex Nan Kivell Collection; NK12/74, National Library of Australia.

106 Rex Nan Kivell Collection NK12/46, National Library of Australia.

107 F. Pound, 'Spectator Figures in Some New Zealand Paintings and Prints', in Art New Zealand, vol. 23, 1982, p. 44.

108 See John C. Blankenagel, 'The Dominant Characteristics of German Romanticism', in Publications of the Modern Language Association of America, vol. 55, no. 1, March 1940, pp. 1-10; D. E. Monson, 'The Classic-Romantic Dichotomy, Franz Grillparzer, and Beethoven', in International Review of the Aesthetics and Sociology of Music, vol. 13, no. 2, December 1982, pp. 161-175; S. Dickson, 'E. T. A. Hoffmann: Mind, Mythology and Meaning', in Forum for Modern Language Studies, vol. 32, no. 3, 1996, pp. 251-263.

109 A. Earle, A Narrative of Nine Months' Residence in New Zealand in 1827; Together with a Journal of a Residence in Tristan D'Acunha. An Island Situated Between South America and the Cape of Good Hope, p. 74.

110 Ibid., p. 74.

111 Ibid., p. 75 .

112 Ibid., p. 77.

113 C. O. Davis, The Life and Times of Patuone: The Celebrated Ngapuhi Chief, pp. 35-9.

114 A. Earle, A Narrative of Nine Months' Residence in New Zealand in 1827; Together with a Journal of a Residence in Tristan D'Acunha. 
An Island Situated Between South America and the Cape of Good Hope, pp. 78-9.

For a ful

nineteenth century, see D. Spurr, The Rhetoric of Empire: Colonial nineteenth century, see D. Spurr, The Rhetoric of Empire: Colonial Discourse in Journalism, Travel Writing, and Imperial Administration, Durham, 1993, chaps. 1 \& 6; B. Korte, English Travel Writing From Pilgrimages To Postcolonial Explorations, London, 2000, chap. 4; J Adler, 'Travel as Performed Art', in The American Journal of Sociology, vol. 94, no. 6, May, 1989, pp. 13661391.

133 At least four images by Earle, with these storage huts as their main subject, were produced by the artist either while he was in New Zealand or within a few years afterwards.

134 Rex Nan Kivell Collection; NK12/80, National Library of Australia. 
135 See R. E. Murphy, The Tree of Life: An Exploration of Biblical Wisdom Literature, New York, 1990. pp. ix-x.

136 A. Earle, A Narrative of Nine Months' Residence in New Zealand in 1827; Together with a Journal of a Residence in Tristan D'Acunha. An Island Situated Between South America and the Cape of Good Hope, p. 100.

137 Ibid., pp. 102-3.

138 Ibid., pp. 111.

139 J-J. Rousseau, A Discourse on Inequality, (trans.) M. Cranston, London, 1984 (1755); J. Savage, Some Account of New Zealand; Particularly the Bay of Islands, and Surrounding Country; With a Description of the Religion and Government, Language, Arts Manufactures, Manners and Customs of the Natives \&c. \&c., London, 1807, p. 18; D. Diderot, in A. Moorehead, The Fatal Impact: The Invasion of the South Pacific 1767-1840, Sydney, 1987, p. 62 .

140 A. Earle, A Narrative of Nine Months' Residence in New Zealand in 1827; Together with a Journal of a Residence in Tristan D'Acunha. An Island Situated Between South America and the Cape of Good Hope, p. 259.

141 H. Williams, in H. Carleton (ed.), The Life of Henry Williams: Archdeacon of Waimate, vol. 1, p. 62.

142 A. Earle, A Narrative of Nine Months' Residence in New Zealand in 1827; Together with a Journal of a Residence in Tristan D'Acunha. An Island Situated Between South America and the Cape of Good Hope, pp. 111-2.

143 P. Moon, This Horrid Custom: The Myth and Reality of Traditional Maori Cannibalism, Auckland, 2008, chaps. 2-4.

144 A. Earle, A Narrative of Nine Months' Residence in New Zealand in 1827; Together with a Journal of a Residence in Tristan D'Acunha. An Island Situated Between South America and the Cape of Good Hope, pp. 113-4.

145 Ibid., p. 114.

146 Ibid., p. 118.

147 Ibid., pp. 118-9.

148 Ibid., p. 120.

149 Ibid., p. 121.

150 Ibid., p. 133.

151 Ibid., p. 156.

152 Op. cit.

153 Ibid., pp. 157-8.

154 Ibid., pp. 159-60.

155 Ibid., p. 164.

156 Ibid., p. 160.

157 Ibid., pp. 160-1.

158 Rex Nan Kivell Collection; NK12/139, National Library of Australia. 
159 A. Earle, A Narrative of Nine Months' Residence in New Zealand in 1827; Together with a Journal of a Residence in Tristan D'Acunha. An Island Situated Between South America and the Cape of Good Hope, p. 169.

Wharepoaka was a son of Rakau, of Rangihoua, of the Hikutu hapu and was one of Hongi's fighting chiefs. He was also a brother of the chief Waikato.

161 W. Williams, Journal, MS, Alexander Turnbull Library, WTU, entry for 30 April 1826.

162 A. Earle, A Narrative of Nine Months' Residence in New Zealand in 1827; Together with a Journal of a Residence in Tristan D'Acunha. An Island Situated Between South America and the Cape of Good Hope, p. 169.

163 Rex Nan Kivell Collection; NK12/69, National Library of Australia.

164 A. Earle, A Narrative of Nine Months' Residence in New Zealand in 1827; Together with a Journal of a Residence in Tristan D'Acunha. An Island Situated Between South America and the Cape of Good Hope, pp. 169-70.

165 Ibid., p. 170.

166 Ibid., p. 171.

167 W. Williams to C.M.S. 27 May 1833, microfilm copy, Alexander Turnbull Library, in E. H. McCormick (ed.), Narrative of a Residence in New Zealand; Journal of a Residence in Tristan da Cunha, By Augustus Earle, p. 23.

168 And also possibly as a result some of the missionaries were having with Captain Duke. See E. H. McCormick (ed.), Narrative of a Residence in New Zealand; Journal of a Residence in Tristan da Cunha, By Augustus Earle, p. 25-6.

169 E. McCormick, Letters and Art in New Zealand, Wellington, 1940.

170 E. H. McCormick, in A. Murray-Oliver, Augustus Earle in New Zealand, Christchurch, 1968, pp. 33-5.

171 Rex Nan Kivell Collection; NK668, National Library of Australia. The catalogue record notes: 'Earle, Augustus, 1793-1838. Sketches illustrative of the native inhabitants and islands of New Zealand. R. Martin \& Co.'

172 Auckland Art Gallery Toi o Tamaki, The Ilene and Laurence Dakin Bequest, 1998, Accession number 1998/32/1/1.

173 A. Earle, A Narrative of Nine Months' Residence in New Zealand in 1827; Together with a Journal of a Residence in Tristan D'Acunha. An Island Situated Between South America and the Cape of Good Hope, pp. 173-4.

174 Ibid., pp. 174-5.

175 Ibid., p. 176.

176 Rex Nan Kivell Collection; NK12/77, National Library of Australia

177 K. Dubinsky, "The Pleasure is Exquisite but Violent": The Imaginary Geography of Niagara Falls in the Nineteenth Century', in J. M. Sloniowsky (ed.), Slippery Pastimes: Reading the Popular in Canadian Culture, Ontario, 2002, chap. 2; A. Pritchard and N. 
J. Morgan, 'Privileging the Male Gaze Gendered Tourism Landscapes', in Annals of Tourism Research, vol. 27, issue 4, October 2000, Pages 884-905; G. Greene, 'Margaret Drabble's "The Waterfall": New System, New Morality', in Novel: A Forum on Fiction, vol. 22, no. 1, Autumn, 1988, pp. 45-65

P. Moon, This Horrid Custom: The Myth and Reality of Traditional Maori Cannibalism, chap 2.

179 In this setting, a mixed-ethnicity relationship could be interpreted as at least undesirable, if not prohibitive, by early nineteenthcentury English viewers.

180 F. Pound, 'Spectator Figures in Some New Zealand Paintings and Prints', pp. 40-45.

181 Ibid., 42.

182 L. B. Alberti, in C. Grayson, (ed. \& trans.), Alberti On Painting and On Sculpture: The Latin Texts of De Pictura and De Statua, London, 1972, in op. cit.

183 A. Earle, A Narrative of Nine Months' Residence in New Zealand in 1827; Together with a Journal of a Residence in Tristan D'Acunha. An Island Situated Between South America and the Cape of Good Hope, p. 196.

184 Ibid., p. 197.

185 Rex Nan Kivell Collection; NK12/79, National Library of Australia.

186 A. Earle, A Narrative of Nine Months' Residence in New Zealand in 1827; Together with a Journal of a Residence in Tristan D'Acunha. An Island Situated Between South America and the Cape of Good Hope, pp. 197-8.

187 Ibid., p. 198.

188 Ibid., pp. 201-2.

189 Rex Nan Kivell Collection; NK12/70, National Library of Australia.

190 C. T. Wilkie, A Suspicion of Fire: Symbols and Meanings within Art and Social Descriptions which Refer to Colonisation, MFA Thesis, Whitecliffe College of Art and Design, Auckland, 2003, p. 36.

191 See E. Said, 'From Culture and Imperialism, "Consolidated Vision", in D. J. Hale (ed.), The Novel: An Anthology of Criticism and Theory, 1900-2000, Oxford, 2006, pp. 691ff.

192 C. T. Wilkie, A Suspicion of Fire: Symbols and Meanings within Art and Social Descriptions which Refer to Colonisation, p. 36.

193 Ibid., pp. 36-8.

194 This is discussed in E. Best, The Maori As He Was, Wellington, 1952, p. 79.

195 Rex Nan Kivell Collection; NK668, National Library of Australia. The catalogue record notes: 'London (26 Long Acre): Lithographed $\&$ published by R. Martin \& Co., [1838]. Extent 1 print : lithograph; sheet $31 \times 42 \mathrm{~cm}$ '.

196 C. T. Wilkie, A Suspicion of Fire: Symbols and Meanings within Art and Social Descriptions which Refer to Colonisation, p. 40.

197 Ibid., p. 41.

198 Ibid., p. 209. 


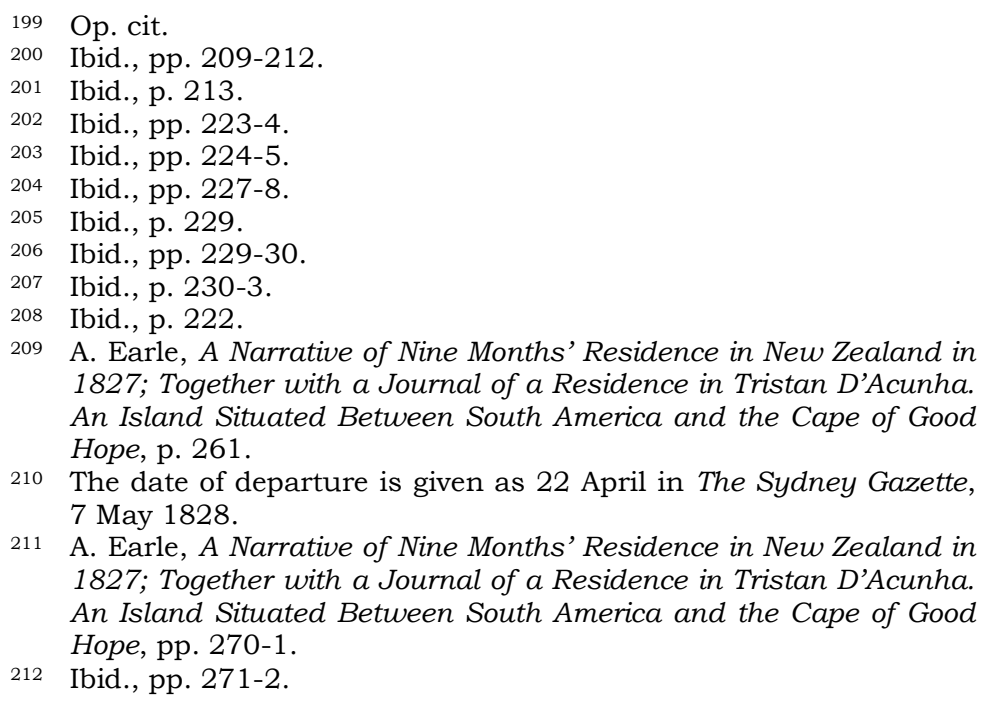

